Portland State University

PDXScholar

Summer 8-31-2018

\title{
Giving the Noose the Slip: an Analysis of Female Murderers in Oregon, 1854-1950
}

Jenna Leigh Barganski

Portland State University

Follow this and additional works at: https://pdxscholar.library.pdx.edu/open_access_etds

Part of the History Commons, and the Women's Studies Commons Let us know how access to this document benefits you.

\section{Recommended Citation}

Barganski, Jenna Leigh, "Giving the Noose the Slip: an Analysis of Female Murderers in Oregon, 1854-1950" (2018). Dissertations and Theses. Paper 4542.

https://doi.org/10.15760/etd.6427

This Thesis is brought to you for free and open access. It has been accepted for inclusion in Dissertations and Theses by an authorized administrator of PDXScholar. Please contact us if we can make this document more accessible: pdxscholar@pdx.edu. 
Giving the Noose the Slip:

An Analysis of Female Murderers in Oregon, 1854-1950

\author{
by \\ Jenna Leigh Barganski
}

A thesis submitted in partial fulfillment of the requirements for the degree of

\title{
Master of Arts
}

in

History

Thesis Committee:

David A. Johnson, Chair

Patricia A. Schechter

Tim Garrison

Kimberly Jensen

Portland State University 2018 


\begin{abstract}
Analyzing the crimes of women murderers and how they faired in the criminal justice system demonstrates that though perceptions of gender evolved, resistance to sentencing women to death often persisted. The nature of homicides committed by women in Oregon set them apart from their male counterparts. Women were, and are, more likely to commit domestic homicides - murders that involve a family member or partner. These crimes are typically not equated with crimes that warrant capital punishment. As a result, no woman has been subjected to the death penalty in the state.

This thesis analyzes the twenty-five women who were convicted of homicide in Oregon between 1854 and 1950. During these years the majority faced all-male court and penal systems. As such, they were handled differently in accordance with various social, cultural, and legislative shifts relating to women's roles as citizens. Through an examination of contemporary newspaper articles, inmate case files, and other Oregon State Penitentiary records, this thesis studies three distinct periods relating to these shifts: 1854-1900, 1901-1935 and 1936-1950.

The assumption that it was impossible for a woman to commit murder linked claims of insanity with criminality. The six women defendants between 1854 and 1900 were either deemed insane and transferred to the asylum or quickly released from prison to avoid potential controversy or additional expense. The twelve women convicted of homicide between 1901 and 1935 all received manslaughter convictions, an occurrence unique to this era. Following the Progressive Era, sentimental juries felt more comfortable convicting women of manslaughter. Many received indeterminate sentences of one to fifteen years and were released on parole. Barganski


The initial first-degree murder charges between 1936 and 1950 signaled a new period in the treatment of women charged with homicide. After gaining the right to vote and serve on juries, women began to be viewed more equally in the eyes of the law. During these years there was a more even distribution of manslaughter, second-degree murder, and first-degree murder convictions for the seven women defendants. This is due in part to women's growing presence in the public sphere.

In conclusion, the idea that women were submissive creatures that required the authority and protection of men in the courtroom began to fade by 1950 . Each period of study demonstrates how the contemporary perception of women and their roles as citizens affected trial outcomes. However, even when women were charged with firstdegree murder they were not sentenced to the death penalty—likely due to the domestic nature of their crimes. 


\section{Dedication}

To my mother Jeryl Barganski, whose unceasing encouragement was invaluable to this process. Thank you for consistently selecting historical fiction books for me at the library. Your choices helped shape mine.

"I am no bird; and no net ensnares me;

I am a free human being with an independent will." -Jane Eyre 


\section{Acknowledgments}

First and foremost, the person that deserves acknowledgment is my advisor David A. Johnson. Though D.J. enjoys frightening graduate students with hefty course loads and high expectations, it was through these expectations that I found confidence in my abilities. Additionally, classes and projects with Katrine Barber and Patricia Schechter significantly influenced my choice to pursue public history as a profession.

Each student in my cohort added something meaningful to my experience at Portland State University, but there is one individual that stands above the rest. When I saw Katherine Nelson walk into our first History 500 class, I knew we were destined to be friends. She wore the same look of bewilderment as myself. In our two years of coursework, Katie and I had nearly every class together. Often the pessimist to my optimist, she has proven herself to be an excellent colleague and confidant.

Taylor Rose was the student that I was initially most intimidated by. He seemed to always have something extraordinarily intelligent to say about everything. I appreciate the comments he gave me early on in my project that helped frame the finished product. Fellow classmates Taylor Bailey and Tanya Monthey are two brilliant minds that make every situation more fun, even though they are cat people.

And finally, to all the family, friends, coworkers, and strangers who listened to me talk about murder for the past few years, I appreciate you. 


\section{Table of Contents}

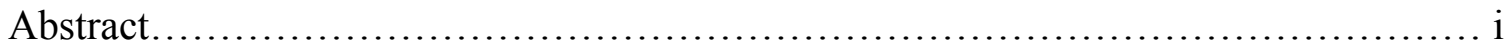

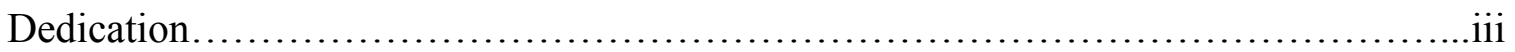

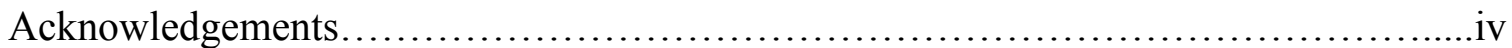

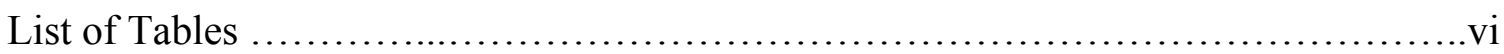

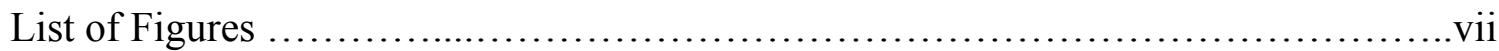

Introduction. ............................................................ 1

Chapter 1: 1854-1900.................................................... 13

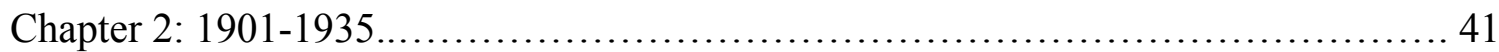

Chapter 3: 1936-1950................................................. 73

Conclusion/Epilogue.......................................................95

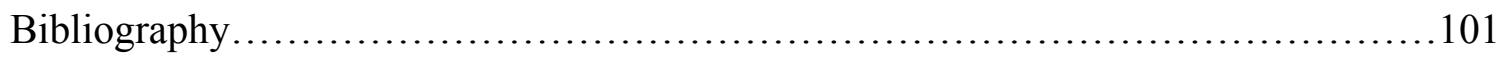

Barganski $\quad$ V 


\section{List of Tables}

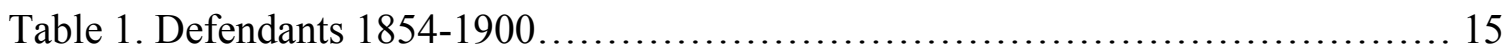

Table 2. Defendants 1901-1935.......................................... 44

Table 3: Methods of Capital Punishment in Oregon, 1864-Present.................. 45

Table 4: Status of Capital Punishment in Oregon, 1864-Present.................... 45

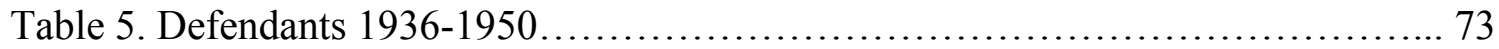

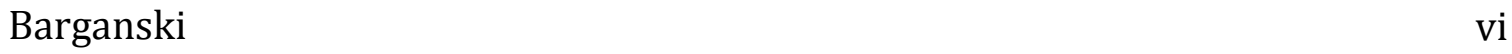




\section{List of Figures}

Figure 1. Advertisement for Oregon Hospital and Insane Asylum, July 23,1862 ...... 20

Figure 2. Oregon Hospital for the Insane on SE Hawthorne, c. $1872 \ldots \ldots \ldots \ldots \ldots \ldots \ldots . \ldots 22$

Figure 3. Caroline Briggs, c. 1870........................................... 23

Figure 4. Population of Oregon State Penitentiary and Oregon State Insane Asylum,

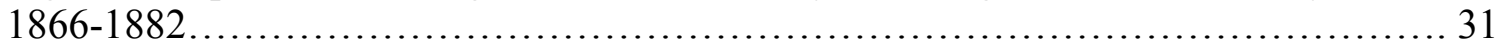

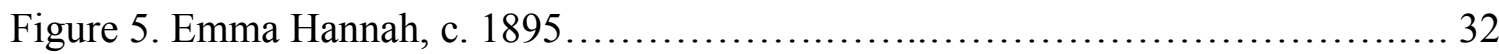

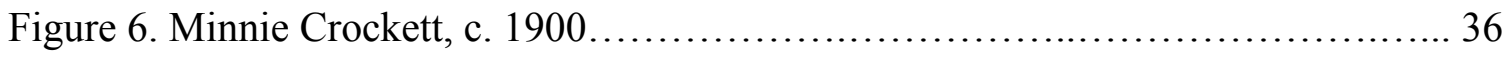

Figure 7: Oregon State Penitentiary Intake Card for Hazel Erwin, 1912 ...................... 43

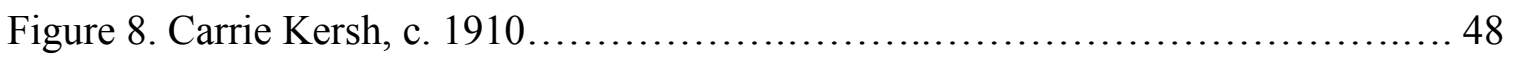

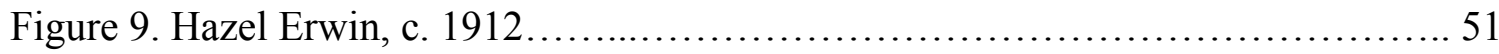

Figure 10. Willard Tanner, c. 1912............................................ 51

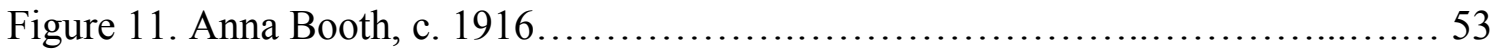

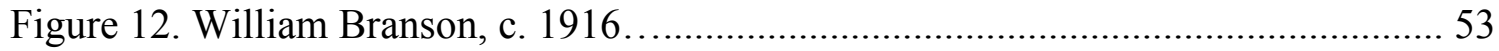

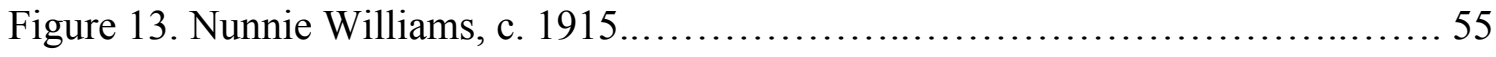

Figure 14. Yvonne Littell, c 1927............................................. 57

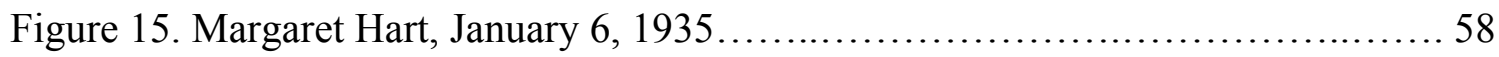

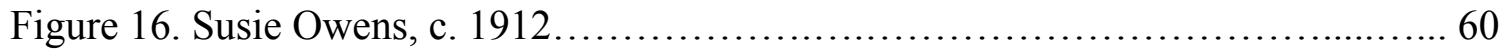

Figure 17. Grace Violette, September 30, 1929.............................. 61

Figure 18. Doreene de Selva, December 27, 1928............................. 62

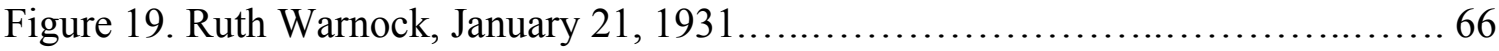

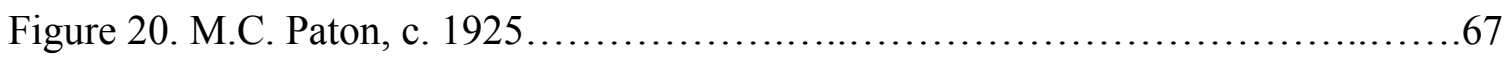

Figure 21. Laura Potts, January 11, 1932....................................... 70

Barganski vii 
Figure 22. Helen Rookard, November 5, 1947.................................75

Figure 23. Atlee Marie Chaboude, November 20, 1950.........................75

Figure 24. Julia Carlson, April 21, 1941.................................... 77

Figure 25. Luella Henagin, December 11, 1946............................... 79

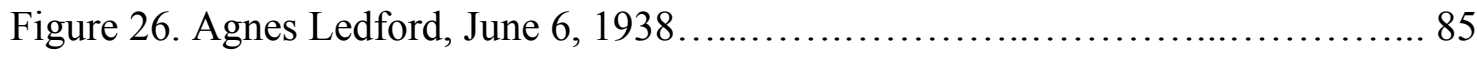

Figure 27. Gladys Broadhurst, March 27, 1947..................................89

Barganski viii 


\section{Introduction}

Of the twenty-five court convicted women murderers in Oregon between 1854 and 1950, nearly seventy percent of them fall under the umbrella of domestic homicide. ${ }^{1}$ Domestic homicides are not typically equated with the crimes that society labels reprehensible enough to warrant capital punishment. As such, no woman has been legally executed in Oregon. ${ }^{2}$ In contrast, between 1854 and today, 112 men were legally executed for murder in the state. ${ }^{3}$ Men are significantly more likely to commit violent crimes, especially predatory murders or murders committed for economic or material gain. ${ }^{4}$ Historically researchers and the media have paid more attention to these crimes and as a result homicides committed by women often escaped public consideration.

The majority of homicidal women between 1854 and 1950 were defended, prosecuted, and judged in an all-male court system. During these years, the twenty-five women defendants in Oregon were handled differently in accordance with various social, cultural, and legislative shifts that followed from women's changing roles as citizens. These shifts occurred in three distinct time periods: 1854-1900, 1901-1935 and 19361950. This thesis demonstrates that dominant ideas about womanhood influenced women murderers' experiences and outcomes in the state's criminal justice system.

\footnotetext{
${ }^{1}$ Domestic homicides are murders that usually take place near the home with family members or significant others as victims.

2 There have been two women sentenced to the death penalty in Oregon since 1950, but the punishment has never been carried out.

3 "Executions in the U.S. 1608-2002: The ESPY File," https://deathpenaltyinfo.org/documents/ESPYstate.pdf.

4 Oregon Department of Corrections, “Oregon Department of Corrections Quick Facts,” Issue Brief, January 2018, http://www.oregon.gov/doc/OC/docs/pdf/IB-53-Quick\%20Facts.pdf.
} 
In the first period, between 1854 and 1900, women criminals were perceived as an irregularity in the system and were poorly managed within male-dominated prisons. Consequently, some were sent to the insane asylum and the rest had their sentences commuted by the governor. The second period, between 1901 and 1935, was one of transition. At the turn of the century Progressive Era changes were reflected in the courtroom as well as the penal system. Officials were unsure how to best handle women murderers in this dynamic environment. As a result, every woman charged with homicide was convicted of manslaughter regardless of the circumstances of the crime. By the mid-1930s women started to serve as jurors on felony trials and were viewed more equally in the eyes of the law. Accordingly, between 1936 and 1950 the first two women received first-degree murder convictions.

There is limited secondary literature that examines women criminals, especially women murderers in Oregon. The subject may have been overlooked due to seemingly insufficient primary sources. However, a handful of historians provide a foundation for further inquiry. For example, Ronald Lansing's article, "The Tragedy of Charity Lamb: Oregon's First Convicted Murderess," offered an introduction to the subject of Oregon's women murderers. ${ }^{5}$ Though his article focused on one case, Lansing offered a model for local legal history and demonstrated how to study Oregon's judicial and penal system. This thesis uses Lansing's format when discussing individual cases - the back-story, murder and arrest, trial proceedings, sentencing, and aftermath.

\footnotetext{
${ }^{5}$ Ronald B. Lansing, “The Tragedy of Charity Lamb: Oregon's First Convicted Murderess," Oregon Historical Quarterly, no. 101 (2000): 40-76.
} 
Anne M. Butler's Gendered Justice in the American West analyzed western women inmates in male penitentiaries between 1865 and 1915. She concentrated on this time period because it "mirrored much of the social, economic, and political struggle that accompanied western change." 6 Butler documented several instances of female prisoners in the West who suffered mental breakdowns and were relocated to insane asylums. She argued that nineteenth-century U.S. prison systems were not initially organized to accommodate female inmates. This seriously affected the women kept within prison walls. ${ }^{7}$ Initially, it was not common to hire matrons to manage to female criminals. Prison was considered no place for a woman. It was more problematic to keep them than release them.

Though Butler focused on the West, she did not study Oregon's female criminals within male penitentiaries. She explained that she did not include Oregon, Washington, or California because the coastline states maintained a different historical narrative than the inland West. ${ }^{8}$ However, many of her conclusions about the treatment of women inmates align with what I found in the archives about women maintained at Oregon State Penitentiary. As there was no national standard for inmate documentation until 1904, Butler experienced difficulty locating records for women criminals within the prison systems she studied. I encountered similar challenges in my research. It was necessary to

\footnotetext{
${ }^{6}$ Anne M. Butler, Gendered Justice in the American West: Women Prisoners in Men's Penitentiaries, First Edition (Urbana: University of Illinois Press, 1997), 4-5.

${ }^{7}$ Butler, 4-5.

${ }^{8}$ Butler, 4-5.
} 
read between the lines of sources to understand each a case and the circumstances of sentencing. 9

Likewise, Ann Jones' Women Who Kill examined the history of American female murderers and their punishments. Jones argued that in a paternalistic culture, men defined women criminals as a result of society losing its moral compass. Many refused to believe that women were capable of violent acts except for the influence of insanity. Jones examined at length parricide and the systematic diagnoses of hysteria that were regularly used to defend women guilty of murder. ${ }^{10}$ Jones focused most of her attention on cases that occurred on the east coast. I expand on several of her arguments in my discussion of female murderers in Oregon.

Another relevant study is Gordon M. Bakken and Brenda Farrington's, Women Who Kill Men. Bakken and Farrington examined select cases of women murderers in California between 1870 and 1958. The authors compared how women were publically represented over the course of nearly a century in attorneys' arguments, judicial rulings, and the media. They periodized their discussion into three stages and argued that the first period, the "long nineteenth century," lasted until World War I. ${ }^{11}$ The authors contended that values of true womanhood and elements of perceived hysteria filtered into courtrooms. After WWI, the "new woman" ideal in the 1920s and 1930s surfaced along with battered women's arguments of self-defense. The authors noted the transition from the "unwritten law," or the murder of a libertine, to "homicidal jealously" and the notion

\footnotetext{
9 Butler, 8.

10 Ann Jones, Women Who Kill (New York: The Feminist Press at CUNY, 2009), 189-97.

11 Gordon M. Bakken and Brenda Farrington, Women Who Kill Men California Courts, Gender, and the Press, Law in the American West (Lincoln: University of Nebraska Press, 2009), 17.
} 
that a woman could commit violent acts no longer surprised the public. ${ }^{12}$ The cultural and economic changes that followed World War II in 1940s and 1950s altered how women were commonly perceived. Bakken and Farrington argued that prior to WWII, California courts concluded that many homicides by women were justified. During this period, however, prosecuting attorneys also cited greed as a motive for murder. ${ }^{13}$ I also discovered that greed, along with deceit, were motives in Oregon homicides between 1936 and 1950. Though my analysis aligns with Women Who Kill Men, I devote more attention to how women were treated in the penitentiaries rather than the press.

Furthermore, I examine the contemporary literature about the criminality of women and the relationship between scholarly assumptions and patterns of convictions and sentences of Oregon's female murderers between 1854 and 1950. The two most prominent studies within the time period include Cesare Lombroso's The Female Offender (1895) and Otto Pollak's The Criminality of Women (1950). ${ }^{14}$ Lombroso argued that criminals were born offenders who could be identified through certain physical attributes. Oregon State Penitentiary (OSP) inmate records prior to 1900 frequently included a thorough physical depiction [Fig. 7]. ${ }^{15}$ Additionally, several local newspaper articles between 1854 and 1900 offered detailed physical descriptions of defendants, reflecting Lombroso's theories. Otto Pollak maintained that society's perception of females as less criminal was a myth. He argued that women were inherently

\footnotetext{
12 Bakken and Farrington, 188.

13 Bakken and Farrington, 190.

14 Cesare Lombroso, The Female Offender (D. Appleton and Company, 1895); Otto Pollak, The Criminality of Women (Philadelphia: University of Pennsylvania Press, 1950).

15 This could also be used as a substitute for a photograph.
} 
more deceitful than men and often went undiscovered and unpunished. ${ }^{16}$ Pollack's focus on the deceitful woman is reflected in several prosecuting attorneys' arguments and newspaper articles that covered women murderers between 1936 and 1950 .

The secondary source that provided the most important point of departure was Diane Goeres-Gardner's study of women criminals in Oregon. ${ }^{17}$ She analyzed select cases of women defendants between 1854 and 1920, including five convicted murderers. ${ }^{18}$ From her book I compiled a preliminary list of homicidal women between 1854 and 1950 to examine trends in cases, trials, and punishments. Goeres-Gardner organized the chapters of Murder, Morality, and Madness thematically according to crime, motive, and outcome. Though there was some overlap regarding the women in Goeres-Gardner's research and this thesis, by choosing to discuss only five convicted murderers, Goeres-Gardner overlooked some key themes that connected female murderers' convictions and sentences to the changing legal and social climates in Oregon.

Following secondary source research I combed Oregonian articles to find the eleven names of murderers Goeres-Gardner listed in the introduction of Murder, Morality, and Madness. ${ }^{19}$ From there, research at the Oregon State Archives (OSA) revealed nine additional female murderers hidden in the thick volumes of the State Penitentiary's “Great Register,” which documented incoming prisoners between 1854

\footnotetext{
16 Pollak, The Criminality of Women, 8-11.

17 Diane L. Goeres-Gardner, Murder, Morality and Madness: Women Criminals in Early Oregon, 1st edition (Caldwell, Idaho: Caxton Press, 2009).

18 Though Goeres-Gardner provided a comprehensive list of women criminals in Oregon between 1854 and 1920, she only wrote full summaries about five of the eleven convicted murderers.

19 Goeres-Gardner, Murder, Morality and Madness: Women Criminals in Early Oregon, xvi-xvii.
} 
and $1946 .{ }^{20}$ The entries in the Great Register provided basic data, including the inmates' names, crime convictions, length of sentences and the county in which they were tried and convicted. ${ }^{21}$ The Oregonian provided the names of five additional women convicted of homicide between 1946 and 1950. This study concludes with 1950, as sources become more heavily redacted and difficult to access.

The most integral primary source was the OSP inmate case files maintained at OSA for incarcerations between 1851 and $1932 .^{22}$ These files include commitment papers from the convicting county, parole records, mug shots, and correspondence related to the inmate. The files were essential to building a narrative of the murder cases, including information regarding the nature of the crime and the relationship between the defendants and their victims. Some case files included medical records and psychological assessments, which helped explain the use of the insanity plea and asylum commitments. For defendants after 1932, the Oregon Department of Corrections released mug shots and limited information maintained in inmate case files. Court records from the Multnomah and Clackamas County Courthouse archives offered more complete timelines of the judicial and penal process. Additionally, the Oregonian provided further names of female murderers and insights into the public's opinion of the defendants.

The chapters of this thesis are organized chronologically according to three time periods: 1846-1900, 1901-1935, and 1936-1950. Each chapter highlights the defendants

\footnotetext{
20 “Great Register,” 1854-1946, Vols. 1-9, Oregon State Penitentiary Inmate Records, Oregon State Archives, Salem, Oregon.

${ }^{21}$ In some cases the Great Register also included physical descriptions, nativity, literacy, and religion of women murderers.

22 Inmate Case Files, 1853-1932, Boxes 1-64, Oregon State Penitentiary Inmate Records, Oregon State Archives, Salem, Oregon.
} 
sentenced within the given date range, provides details of the case, court outcomes and the resultant punishments. I acknowledge the changing social and legal environments that directly affected how Oregon women were perceived and treated inside the courtroom and correctional institutions. ${ }^{23}$

When Charity Lamb was charged with murder in 1854, the existing prison system was ill-equipped to maintain inmates, especially women inmates. ${ }^{24}$ In 1845 , the Oregon provisional government constructed the first log jail in Oregon City. The structure burned down a year later and it took nearly a decade to build a replacement. ${ }^{25}$ In 1851 the territorial government initiated a plan to construct a new facility, but due to lack of funding the Portland Penitentiary was not completed until 1857. Eighteen inmates, including Lamb, were incarcerated behind its walls. By 1859 the prison population doubled and the government made the decision to lease the penitentiary to "private entrepreneurs" to relieve pressure from the mounting costs of prison management. ${ }^{26}$ The early years of the Portland Penitentiary proved disastrous, and the institution was plagued with prison breaks. The state resumed control of the prison in $1862 .{ }^{27}$

In 1866, inmates from the Portland Penitentiary were transferred to temporary quarters in Salem. The permanent buildings of OSP were completed between 1871 and

\footnotetext{
23 It is necessary to note that historic definitions of manslaughter, second-degree murder and first-degree murder may differ from current definitions. Records that disclose these possible changes are not readily available.

24 The first woman charged for any crime in Oregon was Charity Lamb for second-degree murder in 1854. The Portland Penitentiary had yet to be completed and prisoners were shackled inside of an out-of-business storefront.

25 Ward M. McAfee, “The Formation of Prison-Management Philosophy in Oregon, 1843-1915," Oregon Historical Quarterly 91, no. 3 (1990): 259.

26 McAfee, 259.

27 The same year Lamb was transferred to Dr. James Hawthorne's newly built insane asylum in Portland.
} 
1872, and conditions there were brutal in these first years. Officials widely utilized the "Oregon Boot" (a heavy lead or iron band that locked around the ankle and attached to the heel of a boot), and inmates were required to work in various systems of contractual labor. ${ }^{28}$ Though OSP continued these practices well into the Progressive Era, several other states had abolished contract labor in their prison systems by the $1890 \mathrm{~s} .{ }^{29}$

The first chapter of this thesis examines the six women convicted of murder before 1900 that were either sent to the insane asylum or had their sentences commuted by the governor [Table 1]. ${ }^{30}$ Of the four women who received life sentences, only two served life - in the asylum. The longest sentence the others served was eight years. Nineteenth-century women were assumed to possess virtues of domesticity, submissiveness, piety and purity. Their place was within the domestic sphere of the house and family. Women criminals went against these prevailing ideals of true womanhood. ${ }^{31}$ As such, male jurors and court officials were unsure how to best handle cases that involved female defendants whose crimes contradicted these values.

At the turn of the twentieth century, true women ideals started to fade as women carved out a place in the public sphere. ${ }^{32}$ Women first gained voting rights in the western

\footnotetext{
28 One of the first forms of labor was brickmaking between 1871-1874, also flax production. Women inmates usually worked in sewing rooms.

29 McAfee, 261

30 Several other women were likely acquitted for murder. Women who were acquitted essentially rest outside of the scope of this project as locating these records without the trial dates, names of defendants and victims has proven difficult. Some acquittals that I came across in my research include: Mary Gysin Leonard (1878), Myrtle Luckey (1946), and Virginia Harington (1947).

31 Barbara Welter, “The Cult of True Womanhood: 1820-1860," American Quarterly 18, no. 2 (July 1, 1966): 151-74, https://doi.org/10.2307/2711179.

32 One prominent example of this can be seen in the Oregon Supreme Court case Muller v. Oregon (1908). The court ruled that the workday for female wage earners must be limited to ten hours. The defense used contemporary medical and sociological evidence to argue that overwork was harmful to female health and
} 
United States. In 1873, the Oregon Suffrage Association was established and it led the movement that put women suffrage on the ballot five times before it successfully passed in $1912 .{ }^{33}$ This was only the start of a long journey. Once women broke down one barrier to citizenship, they faced new restrictions. ${ }^{34}$ Jury service and holding office were the next logical steps. Oregon women wasted no time making movements in this direction. Changes in "gendered expectations" complicated how women were perceived. 35

Chapter two discusses how these transformations shaped the treatment of women convicted of murder between 1901 and 1935 [Table 2]. United States' western court systems and prisons still treated female criminals as an irregularity. Accordingly, OSP did not provide segregated accommodations or prison matrons until after 1900 - a reason for the start date of this period. ${ }^{36}$ All twelve women convicted of homicide between 1901 and 1935 received manslaughter convictions, an occurrence unique to this era. This series of manslaughter convictions indicates that male judicial officials and jurors were uncertain how to handle these women. Most received indeterminate sentences that ranged between one and fifteen years, an indication of Progressive Era reforms. In several of these cases, jurors' decisions to convict defendants of manslaughter was a decision for lenience, something that was not always supported by judges, district attorneys, and members of the parole board.

\footnotetext{
that it was the state's duty to protect the bodies of the "bearers of the race." The larger claim being that a woman's biology made her dependent on a man.

33 Kimberly Jensen, "Revolutions in the Machinery: Oregon Women and Citizenship in Sesquicentennial Perspective," Oregon Historical Quarterly 110, no. 3 (2009): 342.

34 Jensen, 344.

35 Jensen, 349.

36 Oregon Legislative Assembly Senate, Journal of the Proceedings of the Senate, of the Legislative Assembly of Oregon, 1899.
} 
Chapter three focuses on the fourteen-years between 1936 and $1950 .{ }^{37}$ Of the seven women convicted of homicide after 1936, two were convicted of first-degree murder - the first two women in Oregon history [Table 3]. The initial first-degree murder charge in 1937 followed the previous years' twelve manslaughter convictions and signaled a new period in the treatment of women charged with homicide. Additionally, after 1936, newspapers indicate that women jurors began to serve on felony trials.

It is important to note that the amount of attention dedicated to a particular defendant in this thesis is related to the available primary source documentation. For example, newspaper reports gave more attention to particularly gruesome murders or acts attached to sensational backstories. These observations contributed to the larger analysis of variances found in the legislative and judicial realms. In many cases, however, there is little information describing the defendants' lives prior to their crimes, or what happened to them after they were released from prison. ${ }^{38}$

Though there was some periodical evidence that women defendants were acquitted of homicide between 1854 and 1950, these cases rest outside the scope of this project. Including them would require an exhaustive search through county circuit court records. Doing so would yield some material about the cases, but not nearly as much information that is provided in case files and media coverage. As such, this thesis focuses on the women who were convicted of homicide.

\footnotetext{
37 The primary reason this study ends at 1950 is because inmate records are redacted and more difficult to acquire due to privacy rules and regulations.

38 Additional information about defendants before their crime and after their release from prison may be tracked through census records or genealogical study.
} 
An examination of these homicidal women offers a long overdue view of the darker side of Oregon women's history and fill a gap in scholarship. Doubtless, there is room for significantly more research on this subject. Some topics that could stem from this research include a consideration of the acquittal process, an extended look at women who committed homicide after 1950, and a larger examination of women in the legal history in Oregon. Additionally, a comparative analysis of men who committed homicide in Oregon and their fate within the criminal justice system would expand our knowledge.

This thesis contributes to a larger discussion about the nature of the criminal justice system and criminal justice reform movements. Furthermore, it provides a new avenue for examining gender in Oregon, as well as the United States history. The defendants in each chapter reveal how changing perceptions of women murderers were reflected in court decisions. Overall, the stories of these twenty-five women act as a lens to understand both gender politics and the greater narrative of Oregon and United States penal and judicial history. 
The fate of every female prisoner confined in the penitentiary for any length of time has been a transfer to the asylum for the insane either in account of real derangement of the mental faculties, or official pity which assumes that they are insane, and transfers them to where there are surroundings which make fresh air and exercise possible to them. ${ }^{1}$ - East Oregonian, November 13, 1900

Between 1854 and 1900, the era of the "True Woman," Americans perceived women as inherently morally superior and less violent than men. The true woman was modest, delicate, and submitted to male authority. ${ }^{2}$ Carried from the East and Midwest, this nineteenth-century ideal initiated forms of what, at first glance, might appear like chivalry within the male-dominated justice process. ${ }^{3}$ In Oregon and nationwide, male jurors and court officials were unsure how to best handle women whose actions did not align with prevailing ideas of how a woman should behave.

It took several decades for women charged with felonies in Oregon to endure long stays in the penitentiary. This was likely not due to a lack of female crime; instead it was because the penal system was not outfitted to maintain them. During the territorial and early-statehood decades, Oregon was ill equipped to maintain prisoners, especially female inmates. Oregon's women prisoners in the nineteenth century were incarcerated alongside men. This was true for nearly every state, especially in the West. Prison officials were confronted with problems regarding how to properly manage an evergrowing population of women criminals within penitentiary walls. Criminal justice and penal systems usually dealt with young male criminals and structured their institutions

\footnotetext{
${ }^{1}$ East Oregonian Tuesday, November 13, 1900

2 Welter, "The Cult of True Womanhood."

3 Clarice Feinman, Women in the Criminal Justice System (ABC-CLIO, 1994), 11-13.; Jones, Women Who Kill, 95-100.; Sergio Herzog and Shaul Oreg, "Chivalry and the Moderating Effect of Ambivalent Sexism: Individual Differences in Crime Seriousness Judgments," Law \& Society Review 42, no. 1 (2008): 45-74.
} 
with this population in mind. As such, in 1845 a prison inspector at the Alton Penitentiary in Illinois remarked that "one female prisoner is of more trouble than twenty males." 4 Prison officials claimed women were more difficult to manage and the root cause of other problems relating to the management of male inmates. ${ }^{5}$ They argued that women required additional supervision and had individual needs, so they could not be disciplined as a collective unit.

In line with these social conventions, some of Oregon's prison superintendents, governors, and reform groups were convinced that removing female criminals to asylums was preferable to prison sentences. ${ }^{6}$ They were not mistaken in their assumption that jail was a dangerous place for a woman. However, homicide was not a crime that could be ignored. Patriarchal conceptions of women's nature mitigated convictions. Only when the crime was conducted in front of witnesses, or the evidence was too clear to ignore, were women convicted. Accordingly, between 1854 and 1900 the six women convicted of homicide in Oregon were either sent to the asylum or had their sentences commuted by the governor. Of the four women who received life sentences, only two fulfilled these sentences — in the asylum, not the penitentiary. ${ }^{7}$ Eight years was the longest period any of the other women defendants served in prison [Table 1].

\footnotetext{
4 L. Mara Dodge, “'One Female Prisoner Is of More Trouble than Twenty Males': Women Convicts in Illinois Prisons, 1835-1896," Journal of Social History 32, no. 4 (1999): 912.; The purposeful removal of women inmates was not explicitly expressed in any primary sources that refer to nineteenth-century prison populations in Oregon.

5 Dodge, 912.

6 Senate, Journal of the Proceedings of the Senate, of the Legislative Assembly of Oregon.

7 Charity Lamb was sent to the Oregon Hospital for the Insane (1862-1882) in Portland. Emma Hannah was sent to Oregon State Insane Asylum (1883-1913), later called the Oregon State Hospital (1913Present).
} 


\begin{tabular}{|c|c|c|c|c|c|c|}
\hline Name & Conviction & Date & Sentence & Arrival & Release & Years \\
\hline Charity Lamb & Murder 2 & $5 / 13 / 1854$ & Life & $9 / 18 / 1854$ & Died OHI & Life \\
\hline Caroline Briggs & Manslaughter & $6 / 30 / 1874$ & 15 years & $12 / 4 / 1875$ & $1 / 31 / 1877$ & 2.17 \\
\hline Mary McCormick & Manslaughter & $8 / 5 / 1876$ & Life & $8 / 22 / 1876$ & $11 / 16 / 1878$ & 2.25 \\
\hline Carrie Bradley & Manslaughter & $10 / 28 / 1881$ & 15 years & $1 / 8 / 1883$ & $6 / 21 / 1886$ & 3.5 \\
\hline Emma Hannah & Murder 2 & $9 / 26 / 1895$ & Life & $12 / 1 / 1895$ & Died OSIA & Life \\
\hline Minnie Crockett & Murder 2 & $10 / 2 / 1900$ & Life & $11 / 10 / 00$ & $10 / 14 / 1908$ & 7.92 \\
\hline
\end{tabular}

Table 1. Defendants 1854-1900

Prior to 1900 in Oregon, records and statistics of female prisoners went largely unreported. The names of women prisoners in the State Penitentiary's "Great Register" are generally the only reference to their existence. Inmate case files for female prisoners between 1854 and 1900 provided little information. Record keepers may have thought it best to conceal the presence of females to avoid scandal or attention from prison reformers. Instead they focused on operational procedures and the progress of male inmates. ${ }^{8}$

The case of Oregon's first convicted female murderer exemplifies nineteenthcentury conceptions of female criminals. Charity Lamb killed her abusive husband with an axe at the dinner table on May 13, 1854. At her September trial, Lamb's two appointed defense attorneys claimed that she was not guilty as she was fearful for her life and the safety of her children. Defense attorney James K. Kelly took the position that Lamb was a deranged monomaniac, or partially insane. ${ }^{9}$ Her second attorney, Milton Elliot, claimed that the attack was an act of self-defense, not premeditated. According to

\footnotetext{
${ }^{8}$ Anne M. Butler, Gendered Justice in the American West: Women Prisoners in Men's Penitentiaries (Urbana: University of Illinois Press, 1997), 18.; "Oregon State Penitentiary Biennial Reports" (Salem, Oregon: Oregon State Penitentiary, n.d.), Oregon State Archives, Salem, Oregon.

9 "Trial of Charity Lamb, for the Murder of Her Husband, Nathaniel J. Lamb," Oregonian, September 30, 1854.
} 
Elliot she had suffered years of "domestic tyranny" at the hands of her husband and habitually feared for her life. ${ }^{10}$ Lamb's attorneys' larger assertion was that her husband, Nathaniel, had driven her mad.

By the mid-nineteenth century, domestic violence had declined in most of the country due to increasing bourgeois principles of masculine self-restraint. ${ }^{11}$ Men faced questions about violence against wives, women became resistant to domestic violence, and the larger society began the process of intervention. ${ }^{12}$ However, Oregon was both physically and socially isolated from these developments. ${ }^{13}$ This separation had a direct affect on the levels of domestic violence in Oregon. Abusive husbands in early Oregon maintained their power through enforced isolation and intimidation. This contributed to wives' doubts that they could leave their husbands and shame should they seek a divorce. Moreover, women often felt it was impossible to survive without the financial support of a husband, though it was usually husbands who threatened to desert their wives, and they regularly did. ${ }^{14}$ Not until the 1890s, through the efforts of Abigail Scott Duniway, did wife beating become an issue in court and acceptable grounds for wives to initiate divorce. Women were entitled to seek a divorce if they did not return the violence..$^{15}$ By the close of the nineteenth century, abused women increasingly sought help from their

\footnotetext{
10 "Trial of Charity Lamb, for the Murder of Her Husband, Nathaniel J. Lamb."

11 David Peterson del Mar, What Trouble I Have Seen: A History of Violence Against Wives (Cambridge: Harvard University Press, 1996), 10.; Bakken and Farrington, Women Who Kill Men California Courts, Gender, and the Press, 191.

12 Peterson del Mar, What Trouble I Have Seen: A History of Violence Against Wives, 9.

13 Peterson del Mar, 9.

14 Susan H. Armitage and Elizabeth Jameson, The Women's West, 1st ed. (Norman: University of Oklahoma Press, 1987), 117.

15 Peterson del Mar, What Trouble I Have Seen: A History of Violence Against Wives, 64.
} 
families, law-enforcement, churches, and community groups. ${ }^{16}$ The reasons women were hesitant to do so before ranged from fear of persecution, punishment, and shame.

Between 1854 and 1900, the self-defense plea was utilized in about half of the cases where a woman was convicted of homicide in the state.

Lamb's trial began on September 11, 1854, and lasted six days. ${ }^{17}$ The prosecution and defense questioned and chose twelve male jurors based on their ability to be unbiased toward a female prisoner. Unfortunately for Lamb, the abuse she suffered at the hands of her husband was not a sufficient excuse to warrant her actions. After a few hours of deliberation, the jurors asked presiding judge, Cyrus Olney, to provide clarification in regard to self-defense and justifiable homicide. Olney explained, "If the prisoner believed the deceased was then about to kill her, and that she could not flee without equal danger of being killed, the danger, to her mind, was imminent."18 Instead of remaining a helpless victim, Lamb chose to defend herself against her husband's violence. This choice, attorney Cynthia Gillespie argued, would make a woman "either a criminal or crazy" in court. ${ }^{19}$

Judge Olney followed English Common Law doctrine that provided little clarity for judges and lawyers who struggled with evidence and procedural complications that arose from the insanity defense. ${ }^{20}$ A physician was not consulted and it was up to the judge and jury to determine her sanity at the time of the murder. When Lamb's jury

\footnotetext{
16 Peterson del Mar, 69.

17 This was an exceeding long trial for the period.

18 “The Lamb Murder Trial," Oregon Weekly Times, September 30, 1854. Emphasis added.

${ }^{19}$ Cynthia K. Gillespie, Justifiable Homicide: Battered Women, Self-Defense and the Law (Ohio State University Press, 1989), 13.

20 Tighe, "Francis Wharton and the Nineteenth-Century Insanity Defense," 228.
} 
returned they found her guilty of second-degree murder and sentenced her to a lifetime of hard labor. ${ }^{21}$

If this murder had occurred a year or even months earlier, Lamb may have been acquitted. Just prior to her trial, Oregon newspapers criticized the leniency shown in three criminal trials and speculated that Lamb would receive the same clemency. ${ }^{22}$ The Spectator chided, "Think of it ladies! And if any of you feel disposed to walk up behind your husbands or fathers and chop their heads open, why, just "pitch in!"- You are safe in doing so!"'23

However, the evidence and witness testimonies were too strong to ignore. As there was no other institutional option in 1854, Lamb was the first and only woman imprisoned between 1854 and 1862. In 1854 the Portland Penitentiary was under construction on Front and Harrison streets, so Lamb was delivered to the nearby "Sloan's Hotel," an out-of-business whiskey shop where six male inmates were temporarily held. The prisoners were likely kept in irons, as the hotel did not have secured cells. ${ }^{24}$ The Penitentiary was completed later that year and, as the first female convict in Oregon, Lamb remained in solitary confinement for her entire eight-year sentence. In addition to

\footnotetext{
21 "Trial of Charity Lamb, for the Murder of Her Husband, Nathaniel J. Lamb."

22 Lansing, "The Tragedy of Charity Lamb: Oregon's First Convicted Murderess," 43.; Just prior to Charity Lamb's trial, Mary Ann Lamb was acquitted for the murder of her father, Owen Finn was given the minimum sentence for burning down his neighbor's barn, and Chevalier Richardson killed his neighbor's ox but his case was dismissed for reasons of insanity.

23 "When Will the next Farce Be Played? In September?," Oregon Spectator, July 14, 1854.

24 Ronald B. Lansing, "The Tragedy of Charity Lamb, Oregon's First Convicted Murderess," Oregon Historical Quarterly 101, no. 1 (2000): 68.
} 
being the sole female prisoner, Lamb was the only woman in the whole institution, as the first matron was not hired to work in the prison until $1900 .^{25}$

Quaker missionaries Robert and Sarah Lindsey visited the prison in December 1859 and commented, "the only female prisoner in the place [Charity Lamb]... remarked that she had not done anything wrong." The Lindseys were "inclined to believe that she [was] not sound of mind."26 It is unclear whether Lamb was insane prior to her imprisonment, lapsed into madness after eight years of solitary confinement, or was removed from the jail for bureaucratic reasons. ${ }^{27}$ Her inmate case file simply states that she was sent to the newly constructed Oregon Hospital for the Insane in southeast Portland on December 2, 1862, where she remained until her death in September $1879 .{ }^{28}$ Lamb was among Dr. James C. Hawthorne's first patients at the hospital. Hawthorne moved to Portland from Sacramento in 1857 and began his career treating the impoverished sick. He became interested in opening a hospital to care for the state's poor and mentally ill after he recognized the dire need in the region. His business partner, Dr. Abraham M. Loryea, arrived in Portland from San Francisco in 1859 and shared Hawthorne's intent to open an institution. ${ }^{29}$ In 1861 they constructed a temporary

\footnotetext{
25 Senate, Journal of the Proceedings of the Senate, of the Legislative Assembly of Oregon.

${ }^{26}$ H. S. Nedry, "Willamette Valley in 1859: The Diary of a Tour," Oregon Historical Quarterly 46, no. 3 (1945): 252-253.; Italics added.

27 There were several instances of female prisoners who suffered mental breakdowns and relocated to insane asylums in the West. Nineteenth-century U.S. prison systems were not initially organized to accommodate female inmates, and the lack of accommodations affected the mental stability of the women kept within the walls. Some issues that caused the onset of insanity included sexual abuse by male inmates and prison guards, as well as the implementation of solitary confinement since designated women's wards were rare; Butler, Gendered Justice in the American West, 1997, 157-58.

${ }^{28}$ Charity Lamb was likely buried in the Lone Fir Cemetery across the street from the site of the Oregon Hospital for the Insane.

29 Olof Larsell, The Doctor in Oregon: A Medical History, First Edition (Binfords \& Mort, 1947), 551.
} 
building to care for patients on Southwest Taylor Street between First and Second

Avenues. Dr. Loryea emphasized that once the state decided to build its own hospital, he and Dr. Hawthorne would turn the patients over to that facility, but in the meantime, they claimed it was the state's moral and financial duty to support the doctors' endeavor [Fig. $1] .30$

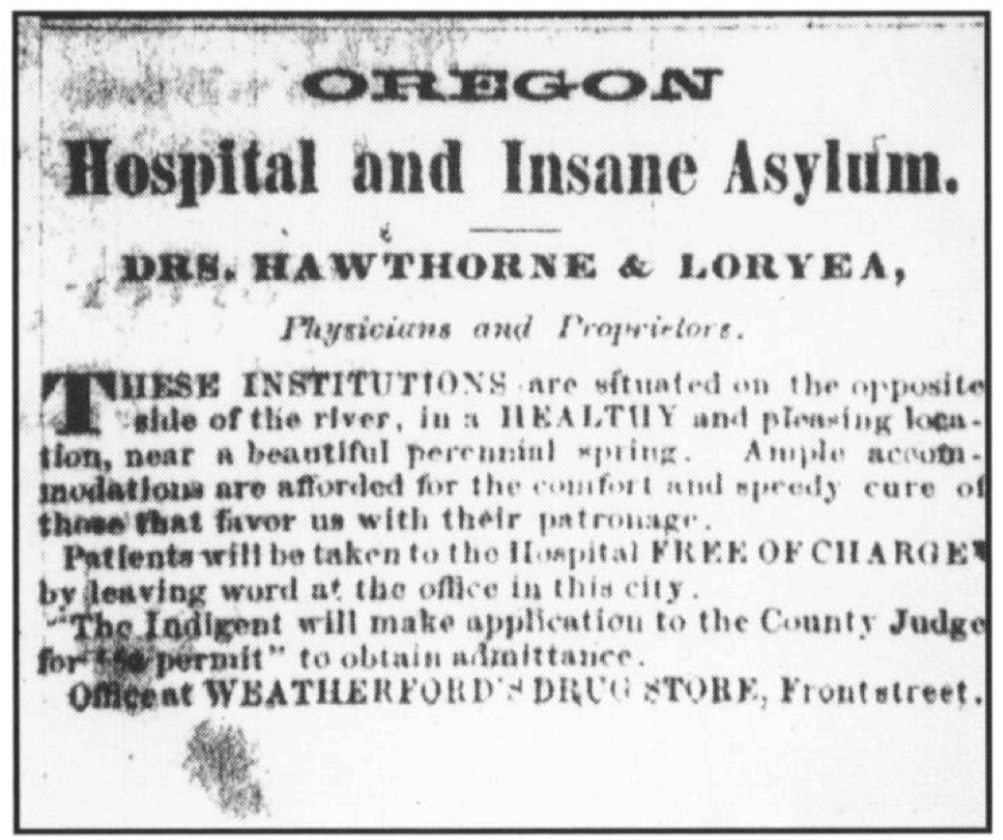

Figure 1. Advertisement for Oregon Hospital and Insane Asylum. The Oregonian, July 23, 1862

In the mid-nineteenth century psychiatry emerged as a medical specialty in the United States. Doctors became more proficient in the study, diagnosis, and treatment of the mind as well as the body. Though their ideas were rudimentary, early psychiatrists, or alienists, had a better grasp of the relationship between social environment and mental illness. They held that if a person was removed from the cause of their insanity, they had

\footnotetext{
30 J.C. Hawthorne, "Report of the Physicians of the Oregon Hospital of the Insane for the Years 1863-64" (W.A. McPherson State Printer, n.d.).
} 
a better chance at recovery. ${ }^{31}$ As such, leading medical professionals circulated the theory that insanity was a potentially curable disease if the afflicted individual underwent treatment in a specialized asylum. ${ }^{32}$

Drawing on the environmentalism of mid-century psychiatry, two schools of thought emerged during this period - the physicalists, who understood the cause of insanity to be physical, and the moralists who determined the cause as moral. Physicalists argued that insanity was a disease of the brain that was initiated by an irritated nervous system or liver, head trauma, or another distinct physical process. Women were thought to be more prone to insanity because of perceived defects in the uterine or ovarian systems that emitted symptoms of hysteria. ${ }^{33}$ Narcotics, opiates, and tonics were the usual prescriptions to combat these ailments. More aggressive treatments included bloodletting, ice baths, and purging. Patients were regularly restrained in leather muffs, straitjackets, and sometimes chains. ${ }^{34}$

Hawthorne built the Oregon Hospital for the Insane with elements of institutional reform in mind. Moralists like Hawthorne focused on repairing the confidence of the patient. During her time at the Oregon Hospital for the Insane, Charity Lamb may have engaged in games, conversation, and forms of mild productive labor like sewing and gardening. Moralists argued that regular schedules promoted self-control, and these

\footnotetext{
${ }^{31}$ Ruth B. Caplan, Psychiatry and the Community in Nineteenth-Century America; The Recurring Concern with the Environment in the Prevention and Treatment of Mental Illness, First Edition (Basic Books, 1969), 29.

32 Andrew Scull, Madhouses, Mad-Doctors, and Madmen: The Social History of Psychiatry in the Victorian Era (Philadelphia, Pa: University of Pennsylvania Press, 1981), 123.

33 Jeffrey L. Geller and Maxine Harris, Women of the Asylum: Voices From Behind the Walls, 1840-1945 (New York: Anchor Books, 1994), 24.; Bakken and Farrington, Women Who Kill Men California Courts, Gender, and the Press, 19.

${ }^{34}$ Geller and Harris, Women of the Asylum: Voices From Behind the Walls, 1840-1945, 25.
} 
doctors insisted on kind and gentle treatment of the inmates. ${ }^{35}$ Doctors tried to emulate the environment of a home, but often kept family members from visiting patients as it might upset the "indulgences and concessions" of the sick patients. ${ }^{36}$

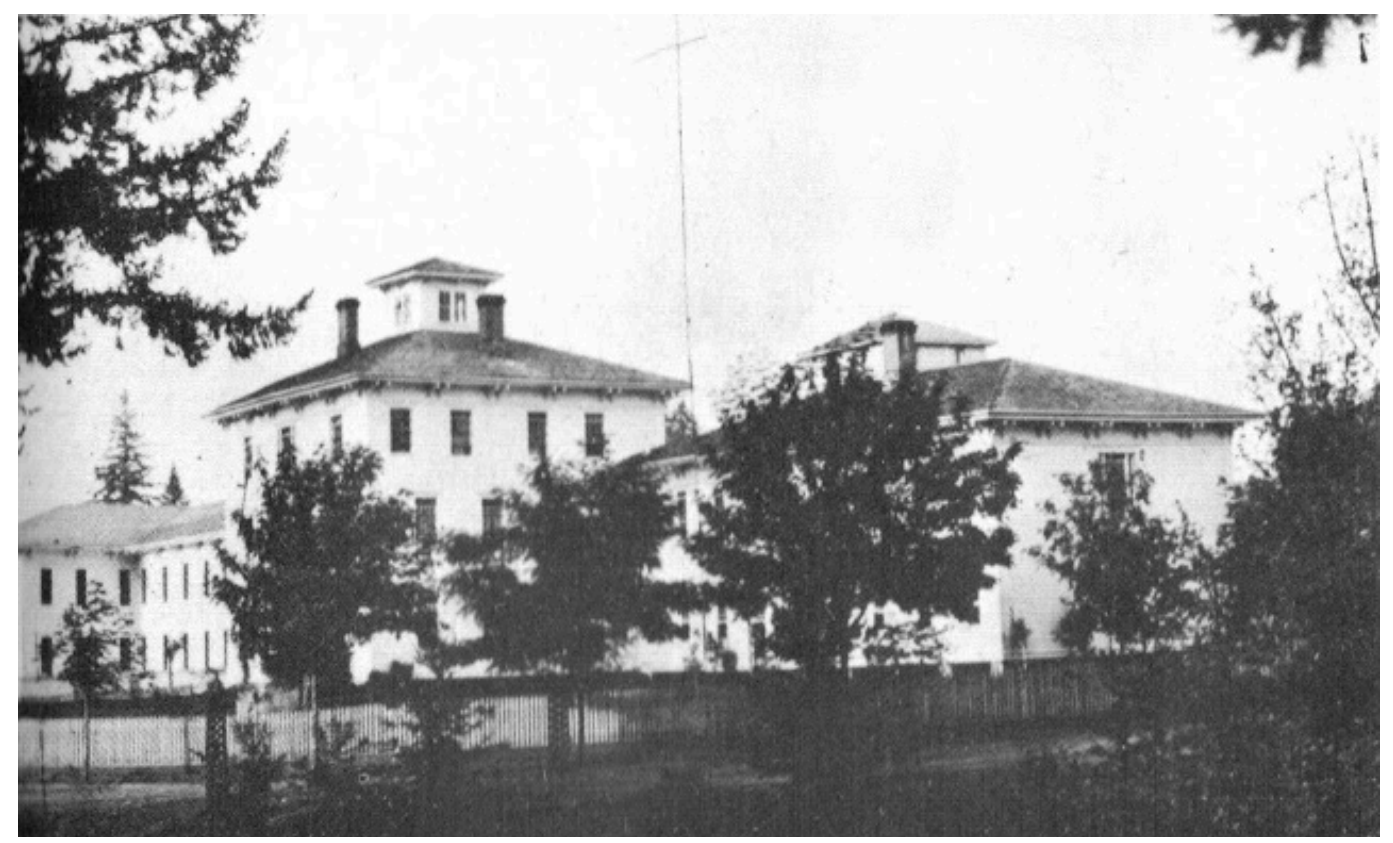

Figure 2. Oregon Hospital for the Insane on SE Hawthorne Avenue, c. 1872. OrHi 26037, Oregon Historical Society

Hawthorne and Loryea's specialized hospital was completed in the summer of 1862 on what is now southeast Hawthorne Avenue between Tenth and Twelfth Avenues [Fig. 2]. On September 29, 1862, the state legislature contracted with the doctors to furnish the facility with the supplies and equipment needed to care for "all indigent, insane, and idiotic persons sent to them by the county court of any county in this state until discharged."37

The emergence of the psychiatric profession, as well as prison and asylum reform, affected the treatment of female criminals. As the field of psychiatry developed in the

\footnotetext{
35 Geller and Harris, 26.

36 Geller and Harris, 26.

37 Hawthorne, "Report of the Physicians of the Oregon Hospital of the Insane for the Years 1863-64."
} 
mid-nineteenth century, the asylum became the accepted facility for the mentally ill, indigent, and others considered deviant. ${ }^{38}$ Various institutional reform movements drove the notion of rehabilitation over punishment and strove to shed light on humanitarian issues. It is uncertain whether the women sent to asylums were indeed insane, or if these institutions functioned more as a custodial facility for unwanted populations labeled as criminal.

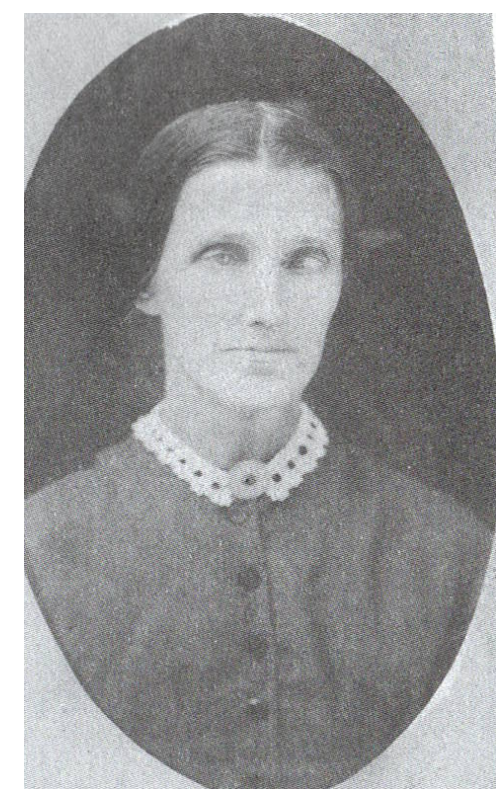

Figure 3. Caroline Briggs, c. 1870.

Dennis E. Strayer Collection, Kerbyville Museum

Twenty years later, in 1874, the circumstances of the second murder committed by an Oregon woman were entirely different from Lamb's case. Caroline Briggs, a fiftyseven-year-old woman afflicted with a severely "crooked eyeball," lived with her family in Kerbyville, Oregon [Fig. 3]. ${ }^{39}$ In June 1874, one of Briggs' daughters died in childbirth. Three days later her seventeen-year-old daughter, Carrie, revealed that her

\footnotetext{
38 Caplan, Psychiatry and the Community in Nineteenth-Century America, 88-96.

39 "Oregon State Penitentiary Case File \#649, Caroline Briggs," n.d., Oregon State Archives, Salem, Oregon.
} 
schoolteacher, John Dalmater had seduced her. Carrie Briggs claimed that she was pregnant with Dalmater's child and that he refused to follow through with his promise of marriage. These two concurrent tragedies sent Briggs into a tormented state. ${ }^{40}$ On June 30, she announced that she was going to make Dalmater pay for his actions and headed toward the schoolhouse. ${ }^{41}$ Briggs' eldest son, David Briggs, followed his mother with a rifle. Briggs confronted Dalmater in front of his students and hit him over the head with her cane. Once outside of the Sucker Creek schoolhouse, Dalmater tried to take the rifle from David Briggs while Briggs continued to whip him with her cane. David Briggs fired several shots and one hit Dalmater as he ran from the scene. Dalmater died a few hours later after he signed a statement that he did not seduce Carrie Briggs. ${ }^{42}$

Briggs and her son were taken to the Kerbyville jail and denied bail. No bail meant that she and her son spent the summer months in the swelteringly hot two-story lumber structure with poor ventilation. ${ }^{43}$ On October 28,1874 , the county grand jury met and indicted Briggs and David Briggs for first-degree murder after eighteen witnesses testified. The defense lawyers asked Judge Prim to postpone the trial until the next court term in April 1875, possibly to give them time to strengthen their argument. ${ }^{44}$

\footnotetext{
40 Democratic Times, July 2, 1875.

41 “State of Oregon v. Caroline Briggs, No. 878, File No. 0777, Journal Entry: Vol. 5, P. 524,” July 5, 1875, Oregon State Archives, Salem, Oregon.; "Oregon Supreme Court Appeals File, Affidavit of Carrie Briggs, Age 17," October 29, 1874, Oregon State Archives, Salem, Oregon.

42 "State of Oregon v. David Briggs, Jackson County Circuit Court State 1 File 32," October 28, 1874, Oregon State Archives, Salem, Oregon.; Deathbed statement from John Dalmater dated October 30, 1874 and witnessed by A.B. McIhvern, Justice of the Peace.

43 Diane L. Goeres-Gardner, Murder, Morality, and Madness: Women Criminals in Early Oregon (Idaho: Caxton Press, 2009), 52.

44 Democratic Times, November 6, 1874.
} 
On October 29, 1874, Briggs submitted an affidavit stating she suffered from mental imbalance and that two doctors were treating her during the time of the attack. Her husband wrote an accompanying affidavit stating that, "I verily believe a further continuance of her imprisonment will seriously endanger her health and life." 45 Judge Prim maintained his decision and again refused bail.

At the next court term in April 1875, Josephine County Sheriff Daniel Green argued for a change of venue for Briggs's trial on the grounds that public opinion in Kerbyville was too biased. ${ }^{46}$ Her trial was moved to Jackson County, where on June 26, 1875 , the jury convicted her of manslaughter, and sentenced her to five years in prison and a fine of twenty-five dollars. Briggs's lawyers immediately wrote an appeal asking that she be released on bail. Judge Prim set her post-conviction bail at eight thousand dollars and friends of the family paid the sum.

In the nineteenth century, killing a "libertine," someone devoid of moral restraint, regularly prompted use of the unwritten law, or "the unwritten code of common humanity," as a defense in U.S. courts. ${ }^{47}$ Men who killed the seducers of their wives or female relatives typically utilized this defense, and they were often acquitted or received a reduced sentence because the act was perceived as ridding the world of evil. Another term for this crime was justified homicide.

\footnotetext{
45 "State of Oregon v. David and Caroline Briggs, Affidavit by George E. Briggs," October 28, 1874, Oregon State Archives, Salem, Oregon.

46 "State of Oregon v. Caroline Briggs, Oregon Supreme Court Appeals File. Affidavit of Daniel Green, Sheriff," April 26, 1875, Oregon State Archives, Salem, Oregon.

47 Oregonian, June 25, 1889.; Robert M. Ireland, "Insanity and the Unwritten Law," The American Journal of Legal History 32, no. 2 (1988): 157-72, https://doi.org/10.2307/845701.; Lawrence Friedman, Crime And Punishment In American History (New York, NY: Basic Books, 1994), 221-22.
} 
On July 9, 1875, the Democratic Times of Jacksonville published a copy of the Petition of Pardon for Briggs that had circulated around southern Oregon. It requested that Governor Stephen Chadwick release this "old lady" with a "nervous nature" who had a hand in killing a libertine. ${ }^{48}$ David Briggs was not included in the petition. Those who signed the petition likely thought that Briggs's poor health affected her decision-making, or that she was justified in her retribution:

That the condition of her health, combined with a shameful misfortune of her youngest daughter, and the death of another daughter, so wrought upon her nervous nature that in an hour of frenzy and without contemplating the result, she committed the act for which she was convicted and sentenced according to the unbending rules law. ${ }^{49}$

The Oregon Supreme Court heard Briggs' appeal on August 2, 1875, but denied her request for a new trial. On November 9, Briggs surrendered herself back to the Jackson County Sheriff and prepared to testify at her son's trial. On November 19, David Briggs was convicted of manslaughter and the judge sentenced him to five years. ${ }^{50}$

On December 4, 1875, Caroline Briggs and her son were sent to the Oregon State Penitentiary in Salem. Briggs endured solitary confinement for the first year and a half of her imprisonment until August 1876, when another convicted murderer joined her. ${ }^{51}$ After Briggs served just over two years of her sentence, Governor Chadwick pardoned her on January 31,1877 . She died twenty years later at the age of seventy-eight. Governor Chadwick also pardoned David Briggs in May 1877. He went on to marry and

\footnotetext{
48 Democratic Times, July 9, 1875.

49 Democratic Times, July 9, 1875.

50 July 2, 1875.

51 Mary McCormick joined Caroline Briggs at OSP in August 1876.
} 
lead a full life. ${ }^{52}$ There is no evidence that Carrie Briggs ever bore a child by John Dalmater. ${ }^{53}$

Caroline Briggs' cellmate, Mary McCormick, could not blame her crime on a nervous disorder or convincingly explain why she killed her victim. In January 1876, fifty-two-year-old McCormick moved to Astoria from Oregon City. McCormick was known for her alcohol addiction and public intoxication, a habit she sustained by working as a laundress. ${ }^{54}$ Her thirty-six year old husband, Mike "Mac" McCormick, followed her to the coast a few years after he was released from prison for killing a "half-breed" in Clackamas County. ${ }^{55}$ Mac McCormick had been convicted of second-degree murder on August 22, 1872, and though Judge Upton sentenced him to life in prison, he was pardoned four months later by Governor L.G. Grover and released on December 18, 1872.

Mac McCormick's job required him to leave town frequently. ${ }^{56}$ When he returned to Astoria from a work trip on August 5, 1876, he was drunk. He ranted that he would not leave his wife alone again — meaning that he had quit his job. Then Mac McCormick left the house and headed straight for Coe's Saloon while McCormick went to the butcher for some meat. The couple later met at the Columbia Ben Saloon, drank some brandy, and went their separate ways. When McCormick returned home after midnight she found her husband already asleep. The next day around noon McCormick yelled for help from a

\footnotetext{
52 Goeres-Gardner, Murder, Morality and Madness: Women Criminals in Early Oregon, 57.

53 Goeres-Gardner, Murder, Morality, and Madness: Women Criminals in Early Oregon, 57-58.

54 Weekly Astorian, August 12, 1876.

55 “Oregon State Penitentiary Case File \#444, Mike McCormick,” n.d., Oregon State Archives, Salem, Oregon.

56 Weekly Astorian, August 12, 1876.; Mac McCormick’s occupation was not stated.
} 
passerby because she thought her husband was dying. The passerby found him in bed with a butcher knife through his heart. ${ }^{57}$

Clatsop County Sheriff William H. Twilight arrested McCormick, and she was arraigned before a grand jury. District Attorney Raleigh Stott called McCormick and five witnesses to testify. Though McCormick pled not guilty and in a written statement accused a man named Hank, the jury voted to indict her with first-degree murder. Court appointed attorneys Robert Fulton and Frank J. Taylor defended McCormick at her trial on August 7, 1876. However, her attorneys were unable to convince the jury of her innocence and they voted to convict her of second-degree murder. ${ }^{58}$ On August 18, Judge E.D. Shattuck asked McCormick if she had anything to say before she received her sentence. McCormick confessed to killing her husband after a drunken brawl but claimed not to remember the fight and insisted the stabbing occurred in self-defense - she did not intend to kill her husband, but he was very cruel and violent.

Though women rarely kill for reasons other than self-defense, historically the law of self-defense has been discriminatory against women. Society generally excluded domestic violence as a motive to kill a husband or partner. ${ }^{59}$ Though Mac McCormick may have been drunk and threatening, McCormick was sentenced to life in prison. However, she served just over two years at the Oregon State Penitentiary during which time she was quite ill. After Caroline Briggs release, McCormick was left alone in her cell for nearly a year and a half. On November 17, 1878, Governor W.W. Thayer

\footnotetext{
57 "State of Oregon v. Mary McCormick, Clatsop County Circuit Court Files, Book 4, Page 489," August $7,1876$.

58 "State of Oregon v. Mary McCormick, Clatsop County Circuit Court Files, Book 4, Page 489."

${ }^{59}$ Gillespie, Justifiable Homicide, 7-11.
} 
commuted her sentence under the condition that she leave the state. ${ }^{60}$ Where McCormick went after her release is unknown.

The only woman who had an existing criminal record before her murder trial was Carrie Bradley, an attractive madam who ran a house of prostitution in Portland. ${ }^{61}$ Between 1877 and 1881 her various run-ins with the law included accusations of lewd cohabitation and larceny, most of which were dismissed in the county circuit court. ${ }^{62}$ Multnomah County District Attorney John F. Caples was irritated with Bradley's ability to skirt the law and was on the lookout for an opportunity to bring down her business and send her to prison. This time came in October 1881 when James Nelson Brown, a fiftythree year old farmer from Washington, filed a police complaint against Dolly Adams, a prostitute employed by Bradley. Brown claimed that Adams robbed him after he had paid for her services. The grand jury indicted Bradley for operating a house of prostitution and Adams for larceny. ${ }^{63}$ Caples agreed to look past Brown's transgressions if Brown promised to testify against both Bradley and Adams. Caples paid a twenty-five dollar bond to ensure that Brown would attend the hearing on October 29, 1881. On the day of the hearing, Brown was nowhere to be found and the case was dismissed.

A few weeks later, on November 18, a corpse was found floating in the Willamette River, which was later identified as Brown. Bradley must have known Caples suspected her involvement in Brown's disappearance because she fled Portland before

\footnotetext{
60 "Executive Clemency. Number Of State Prisoners That Have Been Pardoned, Or Had Their Sentences Commuted," Oregonian, April 8, 1879.

61 Carrie Bradley also went by the alias Emogine Forst.

62 "State of Oregon vs. M.P. Forst and Carrie Bradley," Pub. L. No. 6478 (1878).; "State of Oregon vs. Carrie Bradley,” Pub. L. No. 6681 (1879).“State of Oregon vs. Carrie Bradley,” Pub. L. No. 8194 (1881).

63 “State of Oregon vs. Carrie Bradley,” Pub. L. No. 8194 (1881).
} 
the body was discovered. Adams was arrested for prostitution and brought in for questioning. She admitted she was present the night Brown died and listed the people involved in his murder. She named Bradley and three male accomplices: Pete Sullivan, John Mahone and Charles Hamilton. Bradley was soon arrested in San Francisco and extradited. At her arraignment on May 25, 1882, she was indicted for first-degree murder.

At Bradley's trial, Adams confessed that she went with Sullivan to talk Brown out of testifying and persuaded him to come back to the brothel. Bradley offered Brown free drinks and added morphine to his brandy. Once he had passed out she sent someone to get chloroform, placed a soaked handkerchief over his face, and put him to bed. ${ }^{64}$ The next morning Adams found Brown dead. Bradley, Sullivan, Mahone, and Hamilton then conspired to get rid of the body and dumped it in the Willamette River. ${ }^{65}$

On June 15, 1882, the jury convicted Bradley of manslaughter and the judge sentenced her to serve twelve out of the maximum fifteen years. ${ }^{66}$ She began her sentence at the Oregon State Penitentiary on January 8, 1883. On June 21, 1886, Governor Zenas F. Moody commuted her sentence. ${ }^{67}$ Bradley was released after spending three and a half years isolated in a cell as no other women were imprisoned during that period. What happened to her after her release is unknown.

\footnotetext{
64 "Brown's Body Identified. The Prosecution in the Case of Carrie Bradley Make Several Strong Points," Oregonian, May 27, 1882.

65 “An Accessory’s Statement. Pete Sullivan's Story Of The Murder Of J. N. Brown.” Oregonian, March 9, 1882.

66 "The Trial Ended. Carrie Bradley Convicted of ManSlaughter Two of Her Lawyers Arrested in Open," Oregonian, June 2, 1882.

67 “Oregon State Penitentiary Inmate Register,” n.d., Vol. 3, 1877-1887, Inmate \#1243, Oregon State Archives, Salem, Oregon.
} 


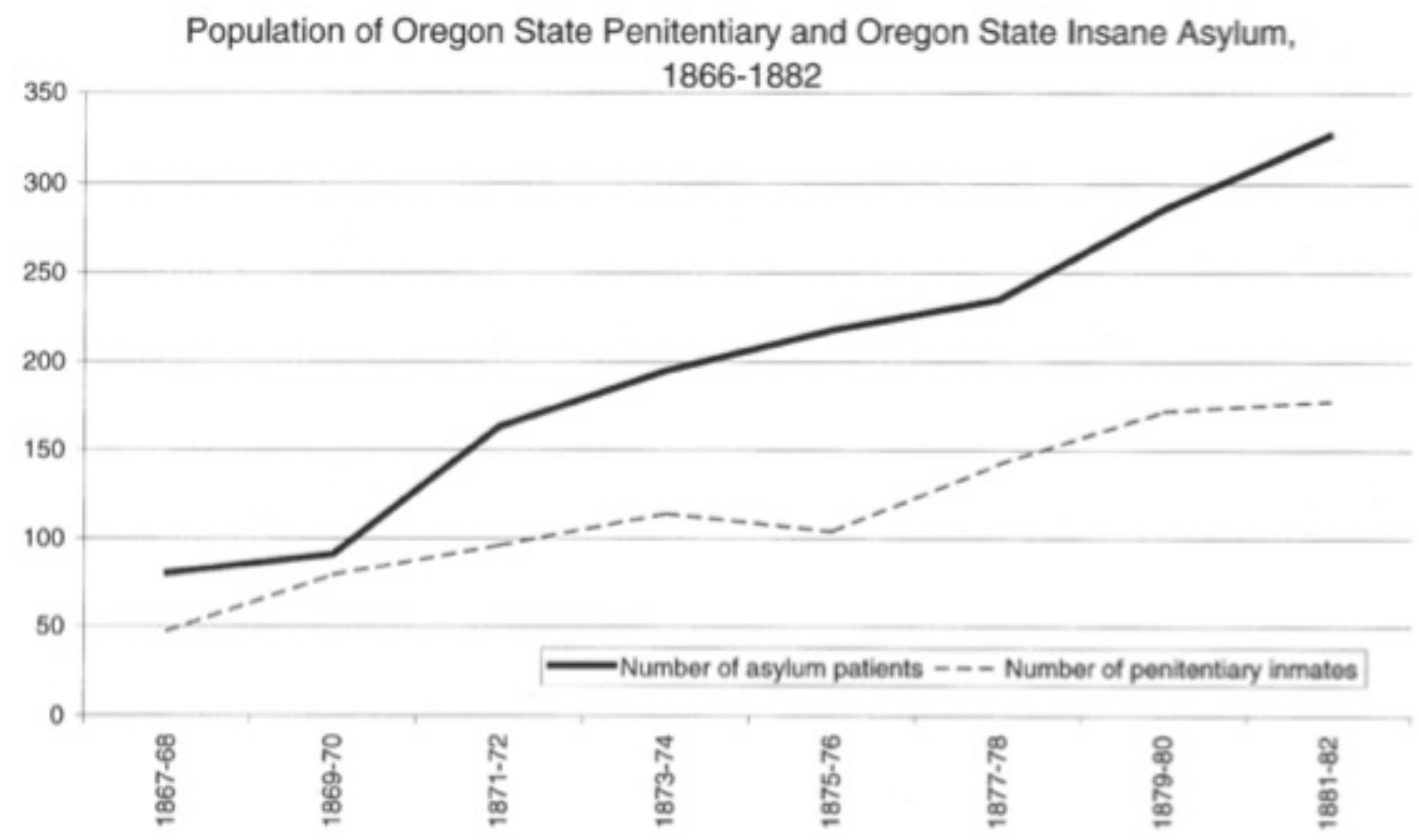

Figure 4. Population of Oregon State Penitentiary and Oregon State Insane Asylum, 1866-1882. R. Rudy Higgens-Evenson, "The Political Asylum: State Making and the Medical Profession in Oregon, 1862-1900," The Pacific Northwest Quarterly 89, no. 3 (1998): 141.

The same year that Carrie Bradley was sent to prison the Oregon State Insane Asylum opened in Salem to replace the Oregon Hospital for the Insane in Portland. ${ }^{68} 268$ male and 102 female patients were relocated to the asylum in October $1883 .{ }^{69}$ By this time, the number of patients in the state asylum was nearly double the number of inmates at the OSP [Fig. 4]. ${ }^{70}$ The asylum population and structure continued to expand, as hundreds of the state's undesirables were unloaded into what became Oregon's infamous psychiatric hospital.

\footnotetext{
68 The Oregon State Insane Asylum in Salem began construction after Dr. Hawthorne's death in 1881.

${ }^{69}$ Larsell, "History of Care of Insane in the State of Oregon," 311.

70 Higgens-Evenson, "The Political Asylum," 141.
} 


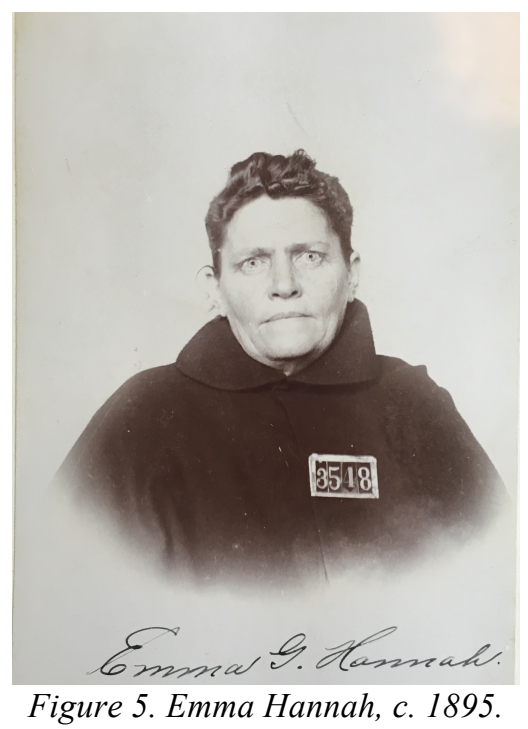

Oregon State Penitentiary (OSP) Inmate Case Files, Oregon State Archives (OSA).

The second woman sent to the insane asylum after committing a murder was Emma Hannah [Fig. 5]. ${ }^{71}$ Hannah's case is distinct as she was the first woman charged with killing another woman. In 1895, Hannah, her husband John Hannah, and their four children farmed hops in Jordan, Oregon. Living on the neighboring farm was twicedivorced woman Charlotte J. "Lottie” (Holman) Hiatt, her elderly mother, Elizabeth Holman, and three-year-old son, Lofa Hiatt. Hannah was convinced that her husband and Hiatt, an attractive redhead, were having an affair. ${ }^{72}$

On September 26, 1895, Hannah disguised herself as an elderly male bookseller and visited the home of Hiatt and Holman. When Hiatt answered the door Hannah pulled out a revolver and fired twice. She missed once and the other shot nicked Hiatt's neck. Holman hit Hannah in the face with a board, which knocked off her hat and false mustache. Hannah pistol-whipped Holman and then pursued Hiatt and shot her on the

\footnotetext{
71 Charity Lamb and Emma Hannah were both sent to the penitentiary prior to the asylum. Doctors assessed others but they remained at OSP.

72 Albany Herald Disseminator, October 4, 1895.
} 
right side of the head, a wound that did not immediately kill the supposed adulteress. ${ }^{73}$ Once Hannah left, Holman picked up her grandson and ran to the closest store for help. Doctors tried to save Hiatt but the bullet was imbedded too deeply into her brain to remove. When questioned about the attack, Lofa Hiatt told Sheriff James McFeron that the shooter had hair long enough to coil on top of his head, which indicated the murderer was a woman. ${ }^{74}$

Sheriff McFeron followed a set of footprints the three hundred yard distance between Hiatt's house and the Hannah farm and questioned each member of the household. Hannah told him that Hiatt's whole family was liars and that they all deserved to be shot. McFeron asked Hannah if Hiatt recognized her when she answered the door. She replied with a laugh, "Oh, I wasn't there: that was a Dutchman with a book to sell. If I'd been Lottie, I would have bought the book; it might have been better for her." She added, "Don't you think it's a nice day for a funeral? I'd like to sing the doxology."75 Hannah's incriminating responses caused her to be swiftly arraigned for attempted murder and placed in the Linn County Jail. Sheriff McFeron had his deputies hang blankets around her cell since the jail was not equipped for a female prisoner. ${ }^{76}$

Hiatt died nine days after the shooting on October 4, 1895. Hannah maintained her innocence and claimed that she spent that whole evening nursing her mouth after the

\footnotetext{
73 Albany Herald Disseminator, November 28, 1895.

74 October 4, 1895.

75 Albany Herald Disseminator, November 28, 1895.; Goeres-Gardner, Murder, Morality and Madness: Women Criminals in Early Oregon, 161.

76 Goeres-Gardner, Murder, Morality and Madness: Women Criminals in Early Oregon, 161.
} 
recent removal of eight teeth and applying a remedy to ease her female complaint. ${ }^{77}$ At the time, Hannah was treating some reproductive ailment, possibly syphilis, a prolapsed bladder, or menopause, which made sexual relations with her husband difficult or painful and contributed to her jealously. Several people came forward to testify that Hannah had expressed concern that Hiatt's presence tempted John Hannah.

On November 8, the Linn County Grand Jury indicted her for malicious and premeditated first-degree murder. On November 26, 1895, the jury convicted her of second-degree murder, and the judge sentenced her to life in prison. Hannah spent two years at the Oregon State Penitentiary before Governor William Lord transferred her on March 20, 1897, to the Oregon State Hospital for paranoid delusions. ${ }^{78}$ The Oregonian may have predicted this would happen a year earlier: "She [Hannah] has grown very nervous, but still stoutly refuses to make a statement as to her guilt or innocence." ${ }^{79}$ After two years in the hospital Hannah returned to the penitentiary on January 11, 1899, allegedly cured of "chronic mania." 80 Her stint at the penitentiary did not last long. Six months later she was sent back to the asylum. A doctor's note from June 1900 stated that she "has delusions of persecution, imagining that the medical students and doctors of

\footnotetext{
77 November 28, 1895.;Goeres-Gardner, Murder, Morality and Madness: Women Criminals in Early Oregon, 163.

78 "Personal and Medical History of Emma G. Hannah" November 11, 1898, Oregon State Archives, Salem, Oregon.

79 “Mrs. Emma Hannah’s Imprisonment Telling Upon Her,” Oregonian, March 17, 1896, 3.

80 “Personal and Medical History of Emma G. Hannah,” November 11, 1898.
} 
Salem are using electricity on her for experimental purposes." 81 She remained at OSIA for the next thirty-three years until her death in 1933 from a cerebral hemorrhage. ${ }^{82}$

At the turn of the century the Catholic Ladies' Social and Relief Society of Salem reported on the deficiencies in the women's ward at the Oregon State Penitentiary. At the same time, it became clear that the assumption that women would never reach a significant portion of the state prison population was incorrect. On February 16, 1899, E.W. Haines, chairman of the committee on penal institutions for the Oregon Senate, submitted the conditions report by the Catholic Ladies' Social and Relief Society to the State Senate. The report concluded "upon careful examination we find that there is no suitable place at the penitentiary for these people [women] except at a very large expense." 83 Haines's committee therefore recommended that female prisoners "might be removed from the penitentiary, either to apartments at the asylum or reform school. Where they might be properly cared for and be furnished with some employment and still be permitted to breathe the open air." 84 Furthermore, the committee recommended that the governor have the authority and power to decide where female convicts should be housed. This aligned with the current protocol of governors sending women to the asylum and commuting their sentences. Though the senate voted fifteen to twelve against the joint resolution, by 1900 Oregon government officials and prison wardens had concluded that female criminals required a designated space within the prison and matrons to attend

\footnotetext{
81 "Personal and Medical History of Emma G. Hannah" June 23, 1900, Oregon State Archives, Salem, Oregon.

82 “Oregon State Hospital Death Book, 1912-1936," Vol. 2G, Oregon State Archives, Salem, Oregon.

83 Senate, Journal of the Proceedings of the Senate, of the Legislative Assembly of Oregon, 775.

84 Senate, 775.
} 
to them. However, it took an additional thirty years for a separate woman's ward to be built at the penitentiary.

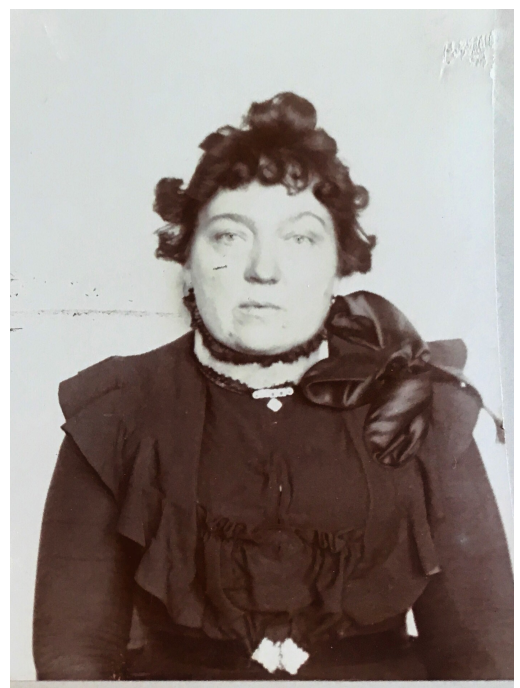

Figure 6. Minnie Crockett, c. 1900. OSP Inmate Case Files, OSA.

In 1900, Minnie Crockett of Milton, Oregon was the first female murderer to be guarded by a matron at OSP [Fig. 6]. Her husband James Crockett returned home from his job as an animal herder for the last time on September 25 of that year. That week James Crockett asked his wife to withdraw their life savings, which included money that she had earned herself. Crockett protested but went into town and withdrew three hundred dollars from the bank, did some shopping, and purchased a pistol. ${ }^{85}$ When she returned home she gave the pistol to her husband. Crockett told authorities that the evening of October 2, James Crockett asked her opinion on suicide and suggested she consider dying with him. She told him she did not want to hear anything else on the topic. ${ }^{86}$

85 East Oregonian, October 5, 1900; East Oregonian, October 9, 1900.

86 October 9, 1900; October 12, 1900; October 13, 1900. 
Later that night while the family slept a single gunshot woke them. James

Crockett's family found him in bed with a fatal bullet wound on the left side of his head. This was curious, as he was right-handed. Crockett denied knowing where the pistol came from until a store clerk testified that she had purchased it from him the day prior. ${ }^{87}$ Crockett admitted she was embarrassed for people to find out she purchased the gun that her husband used to kill himself. Additionally, there was a new oilcloth placed on the bed, which seemed like a premeditative action to prevent blood from ruining the bedding. Finally, their son Earl Crockett testified that he found his father's body in a different position than the investigators found when they arrived. ${ }^{88}$

Though Crockett fiercely maintained her innocence, she was convicted of seconddegree murder at her trial on October 18, 1900. The Oregonian claimed that she received the verdict "with apparent indifference, not exhibiting much interest." 89 The paper went on to say,

The evidence, so far as outlined is purely circumstantial, and there is no probability that the woman will be hanged. Right or wrong, public sentiment is tenacious upon this point, and it would be an atrocious and clearly proven murder that would in most communities send a woman to the gallows. Indeed, the criminal records of the state show that even under such conditions a life sentence in the penitentiary is considered a sufficiently heavy penalty for the law to inflict on a woman. ${ }^{90}$

At her sentencing on November 2, Crockett was asked by Judge Ellis if she had anything to say before sentencing. She replied, "I wish to say that I am innocent of this charge: that

\footnotetext{
87 October 9, 1900.

88 October 19, 1900; October 20, 1900.

89 "Principles in the Milton Murder," Oregonian, October 21, 1900, 4.

90 "Mrs. Crockett; Eastern Oregon," Oregonian, October 21, 1900, 6.; Italics added.
} 
I am in your hands, a helpless woman."91 Crockett was then sentenced to life and committed to the Oregon State Penitentiary. Though other female inmates convicted of lesser crimes periodically joined her, Crockett's time in penitentiary was largely spent in solitary confinement. After eight years in prison, Governor G.E. Chamberlin commuted her life sentence and she was released on October $17,1908 .{ }^{92}$ It is unknown if she returned home to her family after her release.

\section{Conclusion}

Historian Anne Butler wrote "Nothing in the western epic that fascinated the nation after the Civil War allowed for the incarcerated female." 93 Western penitentiaries, including Oregon prisons, were anxious to rid themselves of female inmates. For example, in 1865 Missouri prison warden C.A. Swift told Missouri governor, Charles Fletcher, "anything you can do to reduce the population of the female department of this prison will be a blessing... and a benefit to the institution."94 The contemporary assumption was that women would never reach a significant number in prison populations. In some places this notion carried into twentieth century. Case in point was the Idaho state legislature's allocation of $\$ 1500$ to extend the women's ward of the state penitentiary in $1915 .{ }^{95}$ Governor Moses Alexander vetoed the funding, which aligned with attitudes prominent in the West that viewed female prisoners as an anomaly.

\footnotetext{
91 "Life Term in Penitentiary," Oregonian, November 3, 1900, 4.

92 Oregon State Penitentiary, “Great Register” 1946 1854, Oregon State Archives, Salem, Oregon.

93 Butler, Gendered Justice in the American West, 1997, 32.

94 Butler, Gendered Justice in the American West, 1997, 33.

95 Butler, 33.
} 
Alexander maintained that Idaho would gain no additional female prisoners, though the number had already increased from three to five in one year. ${ }^{96}$

During these years in Oregon it was similarly difficult for male judges and jurors to detach from their understanding of "true woman" ideals in the courtroom. Claims of insanity and other justifications were constantly used in defense of women who acted outside the accepted standards of femininity. Governors commuted the sentences of all convicted women who were not declared insane and committed to the asylums. Most men involved in these cases seemed hesitant to accept that women were capable of violent acts and deflected attention from these perceived glitches by doing everything in their power to keep women out of the prison system.

Society's definition of true womanhood formed penal responses to women who broke the law. In the nineteenth century, female criminals were almost viewed as subhuman when they negated the feminine ideal. Historians have argued this was because nineteenth-century women were held to a higher standard of behavior. When they committed a crime they fell so far from their natural state there was no possibility for reform. ${ }^{97}$ This is seen in the Oregon penitentiary's refusal to provide suitable housing or prison matrons to attend to them until the turn of the century. Once nineteenth-century Oregon women were behind bars their presence was largely ignored. All six of the women studied in this chapter endured long periods of solitary confinement. Aside from

\footnotetext{
96 Butler, 33. All of these female prisoners were kept in one room together.

97 Dodge, "One Female Prisoner Is of More Trouble than Twenty Males"; Lucia Zedner, "Women, Crime, and Penal Responses: A Historical Account," Crime and Justice 14 (1991): 307-62.
} 
sentencing someone to death, solitary confinement is arguably the most brutal form of punishment. 
Chapter 2: 1901-1935

At the turn of the twentieth century the social order and legal system became more complex. Oregon had grown since statehood in 1859 and developed institutions and procedures that more closely aligned with those found elsewhere in the United States. For example, changes that were initiated in the penitentiary during the Progressive Era were meant to provide a philanthropic or enlightened alternative to the cruel practices of corporal and capital punishment. ${ }^{1}$ Another theory is that the actual motivation behind prison reform was to enact order, discipline, and social control on populations deemed dangerous or disorderly. ${ }^{2}$

At the turn of the century there were two distinctive approaches to how the state penitentiary should be managed. Historian Ward M. McAfee argued that these approaches directly related to who held the office of state governor. ${ }^{3}$ Republicans were more interested in heavy security and corporal discipline, and emphasized capital punishment as a deterrent to crime. ${ }^{4}$ In an undated manuscript highlighting Oregon's early prison system Governor Oswald West stated that:

From the middle of the Eighteen Eighties [sic] until the administration of Governor Chamberlin, the State Penitentiary was a hell's hole. Prisoners were flogged, hosed and strung up by their thumbs for the slightest infraction of rules. And when confined to solitary - a dark cell, without bed or bedding, nothing to sit on, and but a bread and water diet. Weeks of such treatment turned prisoners into savage beasts, and when released from solitary they were usually made to wear the Oregon boot. ${ }^{5}$

\footnotetext{
1 Dodge, “One Female Prisoner Is of More Trouble than Twenty Males," 907.

2 Dodge, 908. The theorists Dodge cites in this regard include Michael Ignatieff and Michel Foucault.

3 McAfee, "The Formation of Prison-Management Philosophy in Oregon, 1843-1915," 1990, $267-68$.

4 Governor William P. Lord (1895-1899) and Governor Theodore T. Geer (1899-1903).

5 Oswald West, "Our Prison System in the Days of Old" undated, 7, Box 2, Folder 31, Oregon Historical Society.; Governor George Earle Chamberlain's term in office was 1903-1909.
} 
Democrats, on the other hands, preferred rehabilitation and reform, arguing that humane treatment of prisoners would provide better results once inmates were released. ${ }^{6}$ Reform methods initiated during the Progressive Era, such as indeterminate sentencing, probation and parole, were designed to increase the prisoner's self-respect and autonomy. ${ }^{7}$

Prompted by the ever-changing legal definitions of crime and methods of prison management in the nineteenth century, Italian criminologist Cesare Lombroso sought to find firm scientific categories of women criminals. He argued that "there was an intimate co-relation between bodily and mental conditions and processes," and that may be identified "with an examination of the physical characteristics and peculiarities" of the offender. ${ }^{8}$ In some early cases during this period, Lombroso's theories were utilized on OSP inmates' intake cards [Fig. 7].

Lombroso spent a large part of his career trying to determine the physical differences between good and bad women, or as he called them, the "normal woman" and the "born female criminal." He concluded that "female criminals approximate more to males." This aligned with the notion that women who committed crimes were inherently different than those who conformed to societal standards of behavior. ${ }^{10}$ As such, there

\footnotetext{
${ }^{6}$ Ward M. McAfee, “The Formation of Prison-Management Philosophy in Oregon, 1843-1915," Oregon Historical Quarterly 91, no. 3 (1990): 262.; Governor George E. Chamberlain (1903-1909) and Governor Oswald West (1911-1915)

${ }^{7}$ McAfee, 273; In 1917, state sterilization passed and select prisoners were only eligible for parole once they submitted to the procedure. These methods were initiated during the administrations of Governors Chamberlain and West.

${ }^{8}$ Lombroso, The Female Offender, xv.

${ }^{9}$ Lombroso, 28.

${ }^{10}$ Caesar Lombroso's theories found there way into the Oregon prison system around the turn of the twentieth-century.
} 
was some confusion as to how these women should be handled in the criminal justice system.

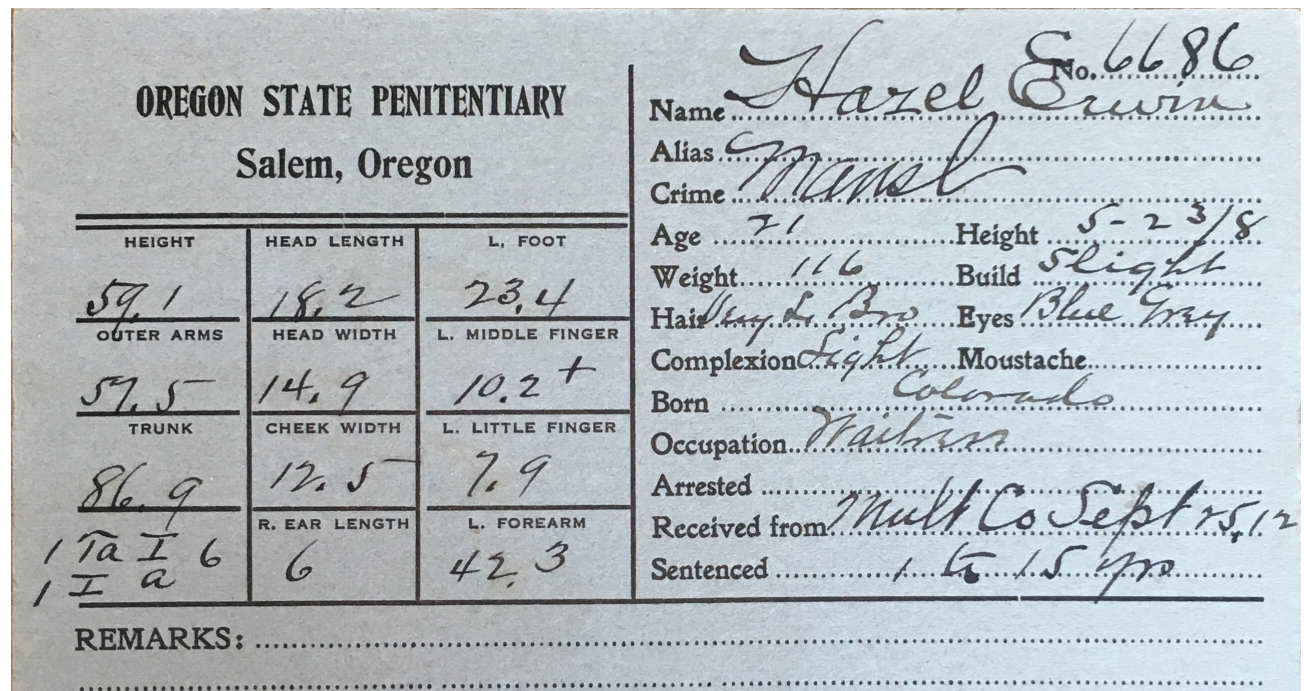

Figure 7. OSP Intake Card for Hazel Erwin, 1912.

OSP Inmate Case Files, OSA.

In addition to changes in prison management, there were important shifts in

legislation and societal norms regarding women's rights. Women's participation in various nineteenth-century institutional and temperance reform movements transitioned into the suffrage movement. After five failed attempts on the ballot, Oregon women gained the right to vote in November 1912. The next month in Portland, Municipal Judge George Tazwell subpoenaed women to form an "experimental" all-women jury to test "the psychology of woman jurors" in a case against a female brothel owner. ${ }^{11}$ Though some women served on civil and misdemeanor cases in the following years, they were

\footnotetext{
11 "Suffrage Leader on Jury," Oregon Journal, December 1, 1912, 4.; Kimberly Jensen, "Kimberly Jensen's Blog: Portland's 'Experimental' Woman Jury, Part II, Oregon Journal December 1 and 2, 1912," Kimberly Jensen's Blog (blog), May 13, 2011, http://kimberlyjensenblog.blogspot.com/2011/05/portlandsexperimental-woman-jury-part_13.html.
} 
able to opt out of jury service until legislation prohibited their preclusion in $1943 .{ }^{12}$ As women started to fill positions that were traditionally held only by men, they became permanent fixtures in the public sphere.

\begin{tabular}{|c|c|c|c|c|c|c|}
\hline Name & Conviction & Date & Sentence & Arrival & Release & Years \\
\hline Carrie Kersh & Manslaughter & $6 / 19 / 10$ & 15 years & $4 / 25 / 11$ & $12 / 14 / 18$ & 7.67 \\
\hline Hazel Erwin & Manslaughter & $6 / 19 / 12$ & Indeterminate & $9 / 25 / 12$ & $6 / 1 / 30$ & 17.75 \\
\hline Susie Owens & Manslaughter & $7 / 12 / 12$ & 15 years & $10 / 17 / 12$ & $3 / 18 / 14$ & 1.42 \\
\hline Nunnie Williams & Manslaughter & $12 / 3 / 15$ & Indeterminate & $1 / 25 / 16$ & $1 / 25 / 18$ & 2 \\
\hline Anna Booth & Manslaughter & $10 / 8 / 16$ & Indeterminate & $3 / 10 / 17$ & $1 / 31 / 20$ & 2.75 \\
\hline M.C. Paton & Manslaughter & $4 / 21 / 25$ & Indeterminate & $5 / 4 / 25$ & $5 / 4 / 35$ & 10 \\
\hline Grace Violette & Manslaughter & $3 / 3 / 26$ & 5 years & $5 / 31 / 26$ & $9 / 30 / 29$ & 4.33 \\
\hline Yvonne Littell & Manslaughter & $1 / 22 / 27$ & 3 years & $5 / 20 / 27$ & $5 / 20 / 29$ & 2 \\
\hline Doreene de Selva & Manslaughter & $11 / 8 / 28$ & 5 years & $12 / 27 / 28$ & $4 / 25 / 32$ & 4.33 \\
\hline Ruth Warnock & Manslaughter & $10 / 12 / 30$ & 7 years & $1 / 21 / 31$ & $9 / 21 / 35$ & 4.75 \\
\hline Laura Potts & Manslaughter & $10 / 4 / 31$ & Indeterminate & $1 / 11 / 32$ & $2 / 6 / 40$ & 8 \\
\hline Margaret Hart & Manslaughter & $7 / 7 / 35$ & 1 year & $1 / 6 / 36$ & $1 / 6 / 37$ & 2 \\
\hline
\end{tabular}

Table 2. Defendants 1901-1935

These shifts influenced how women murderers were handled in the courtroom.

Between 1901 and 1935 all twelve of the women charged with homicide in Oregon were convicted of manslaughter [Table 2]. This pattern was unique to the era and the primary reason for defining this date range. Though the details of the homicides differed, the courts convicted each woman of the same crime. The succession of manslaughter convictions is due in part to all-male jurors' inability to determine the right course of action. It was no longer feasible to assume that a woman was simply insane or unaware of her violent actions. Though judges and juries previously made these decisions on their

\footnotetext{
12 Kimberly Jensen, “Kimberly Jensen's Blog: Oregon Attorney General's Decision December 10, 1912 : Women Can't Serve on Juries -- Historical Connections and a Few Loopholes," Kimberly Jensen's Blog (blog), August 16, 2011, http://kimberlyjensenblog.blogspot.com/2011/08/oregon-attorney-generalsdecision.html.
} 
own, the professionalization of psychiatry brought doctors into the courtroom to determine the mental health of a defendant when their sanity was in question.

Consequently, jurors were faced with two decisions - vote to acquit or send a woman to prison. But to condemn a woman with a more serious sentence than manslaughter possibly meant sending her to her death or a life behind bars.

Capital punishment was made explicitly legal in Oregon by a statute in 1864. Up until 1914 the sentence for first-degree murder was death by hanging [Table 3]. The Oregon legislature repealed capital punishment between 1914 and 1920, but in 1920, it was reinstated for first-degree murder with a provision that the jury could request leniency, in which case the sentence would be life [Table 4]. ${ }^{13}$ The same legislation stipulated that a second-degree murder conviction carried a mandatory life sentence. ${ }^{14}$

\begin{tabular}{|c|c|}
\hline \multicolumn{2}{|c|}{ Methods of Capital Punishment in Oregon 1864-Present } \\
\hline $\begin{array}{c}1864-1914 ; \\
1920-1938\end{array}$ & Death by hanging \\
\hline $1939-1963$ & Death by lethal gas \\
\hline $1978-$ Present & Death by lethal injection \\
\hline
\end{tabular}

Table 3: Methods of Capital Punishment in Oregon, 1864-Present.

\begin{tabular}{|c|c|}
\hline \multicolumn{2}{|c|}{ Status of Capital Punishment in Oregon, 1864-Present } \\
\hline $1864-1903$ & Public execution in local community \\
\hline $1904-1914$ & Private execution at State Penitentiary \\
\hline $1914-1920$ & Capital Punishment repealed \\
\hline $1920-1963$ & Capital Punishment reinstated unless jury recommended otherwise \\
\hline $1964-1977$ & Capital Punishment repealed \\
\hline $1978-P r e s e n t$ & Capital Punishment reinstated only with jury's recommendation \\
\hline
\end{tabular}

Table 4: Status of Capital Punishment in Oregon, 1864-Present.

13 Robert H. Dann, "Capital Punishment in Oregon," The Annals of the American Academy of Political and Social Science 284 (1952): 110-12.; Bill was initiated by Governor Oswald West.

14 The use of parole in Oregon was established in 1905. 
This sequence of manslaughter charges suggests that early twentieth-century male jurors were not ready to shoulder the weight of condemning a woman to life in prison, much less death. Manslaughter convictions thus became a neutral middle ground. Traditional perceptions about the nature of women influenced several states' laws that governed the sentencing and rehabilitation of female offenders. Many states required that women receive an indeterminate sentence while men were given a determinate sentence for similar crimes. ${ }^{15}$ Indeterminate sentencing was frequently mandated for women under the assumption that they were more responsive to rehabilitation, and that the length of their sentence would be a direct reflection of how well they behaved behind bars. ${ }^{16}$ Several female murderers in Oregon between 1901 and 1935 received indeterminate sentences that ranged between one and fifteen years. ${ }^{17}$

Indeterminate sentencing and the parole system reached Oregon by 1905 when state felony-sentencing standards gave the governor full authority to parole prisoners. In 1911 the legislature established the State Parole Board. The board reviewed all cases where inmates were sentenced to indeterminate periods and reported their findings and recommendations to the governor. Any person who was given an indeterminate sentence was eligible for parole by the governor or the Parole Board after they had served the minimum term of one year. Legislation in 1917 required district attorneys and courts to complete Parole Board forms for each parolee with their criminal history and issue these

\footnotetext{
15 Clarice Feinman, Women in the Criminal Justice System (ABC-CLIO, 1994), 8.

16 Feinman, 9.

17 Toward the end of the nineteenth century New York penologist Zebulon Brockway led the reform that initiated indeterminate sentencing and the parole system. See Friedman, Crime And Punishment In American History, 160.
} 
forms to the state parole officer. ${ }^{18}$ The parole board was charged with maintaining communication with all individuals on parole. The law gave penitentiary officials the authority to determine when or if an inmate demonstrated the necessary "moral, mental, and physical transformations" to merit release. ${ }^{19}$ Though this system was intended to encourage prisoners to focus on self-improvement, in actuality they had little power over their own release since several parties including the judge, parole board, and prison officials were usually involved in the decision. These assessments were generally subjective. ${ }^{20}$ Consequently, women were regularly held for longer terms than men before becoming eligible for parole. ${ }^{21}$

When women committed homicide in the nineteenth century lawyers often cited insanity as the driving motive. But in the early twentieth-century medical and legal advances in psychiatry changed perceptions of insanity and its causes. Lawyers shifted their emphasis on female hysteria to actual medical diagnoses. Additionally, defense attorneys started to paint more detailed narratives describing the female defendant, her relationship with the victim, and what prompted her actions. Likewise, newspapers transitioned from focusing on hard facts and trial proceedings to commentaries aimed at evoking an emotional response. Early twentieth-century Oregon journalists researched the background history of defendants and their victims to make determinations about their character.

\footnotetext{
18 "Board of Parole and Post-Prison Supervision Administrative Overview December 2006," 2, accessed May 3, 2017, http://sos.oregon.gov/archives/Documents/recordsmgmt/sched/overview-parole-post-prisonsupervision.pdf.

19 Butler, Gendered Justice in the American West, 1997, 9.

20 Butler, 9.

${ }^{21}$ Feinman, Women in the Criminal Justice System, 1994, 8.; Jones, Women Who Kill, 34-35.
} 


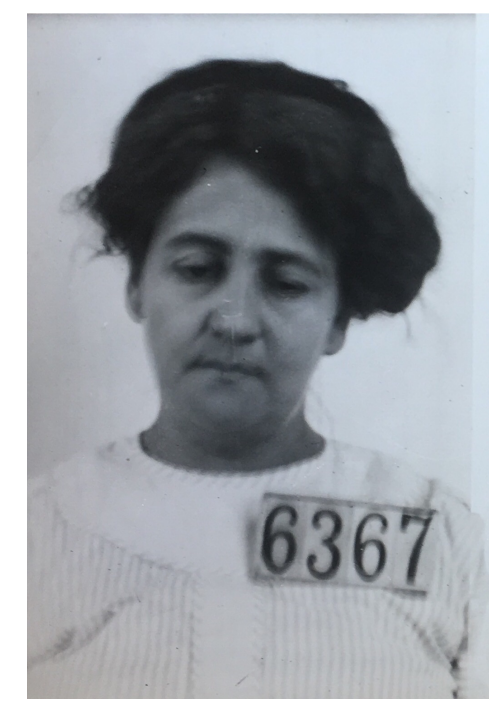

Figure 8. Carrie Kersh, c. 1910. OSP Inmate Case Files, OSA.

In 1910, after a decade without any women convicted of homicide, jurors found Carrie Kersh guilty of manslaughter [Fig. 8]. On June 20 of that year, the body of William A. Johnson was found in a steamer trunk at Portland's train station. At the nearby New Grand Central Hotel police detectives discovered a blood-soaked mattress in Room 119 and corroborating evidence in Room 109.22 The evening prior, William Johnson, "Mrs. Johnson," and a seven-year-old boy had checked into Room 119 of the hotel. Shortly after, a man registered as "C.A. Powers," and the front desk assigned him to Room 109 across the hall from Room 119.23 When questioned by detectives, the hotel clerk stated that on the night of June 19, Mrs. Johnson (Carrie Kersh) left the hotel and

\footnotetext{
22 The New Grand Central Hotel was located on NW Third and Flanders Streets in Portland.

${ }^{23}$ Duane Hennessy, "Grand Central Murder... A Trunk Mystery," Oregonian, September 15, 1935.; "Mrs. Kersh Tells Tangled Stories Woman in Webb Murder Case Said to Have Been Married to Johnson," Oregonian, October 20, 1910.
} 
did not return. The man who registered as "Powers" brought down a trunk with the boy, came back alone and stated that William Johnson had left for Seattle. ${ }^{24}$

Detectives found a boy that matched the hotel clerk's description at a nearby lodging house and waited there for Powers (Jesse P. Webb) to return. Once Webb and the alleged "Mrs. Johnson" arrived at the lodging house, police informed Kersh that Johnson was dead. Webb immediately denied any involvement, but the police found \$1900 on Kersh's person. ${ }^{25}$ She admitted that she was not Johnson's wife, gave her true identity, and informed police that the little boy was her son by Bert M. Kersh, whom she had deserted in Seattle a few days before to be with Webb. ${ }^{26}$

Webb spun a curious tale. He stated that he and Kersh eloped in November 1909 and lived together in Spokane. Webb went on to say that a few days before the murder Kersh told him that she was leaving him for Johnson. Webb begged her not to do so, and decided to follow her. ${ }^{27} \mathrm{He}$ boarded the same train travelling from Spokane to Portland with Kersh and Johnson, met Johnson on the train, and they shared some drinks together. At this point Johnson was unaware of Webb's relationship with Kersh and insisted that Webb stay at the same hotel as them in Portland. Later that evening, Webb, Kersh, and Johnson consumed excessive amounts of alcohol in Room 119. Johnson accused Webb of trying to steal Kersh. When Kersh left the room the men got into a violent brawl. Webb

\footnotetext{
24 "Evidence Against Woman Stronger. Both Jesse Webb and Mrs. Kersh Indicted for First Degree Murder," Oregonian, June 25, 1910.

$25 \$ 1900$ in 1910 equates to $\$ 47,500$ in 2018.

26 Hennessy, "Grand Central Murder... A Trunk Mystery."

27 Hennessy. 
hit Johnson several times over the head and then strangled him until he died. Webb told Kersh what he had done and sent her to go buy a trunk, which she did. ${ }^{28}$

Kersh and Webb were indicted for first-degree murder. Both pled not guilty to "Premeditated striking, beating, outing and wounding him [Johnson]...in and upon the head and body with a club and blackjack and other instruments and weapons... and then...choking, strangling and suffocating him." ${ }^{29}$ On October 21, 1910, the jury found Webb guilty of first-degree murder and the judge sentenced him to hang by the neck until dead. Instead, twelve years later Governor Oswald West commuted Webb's sentence to life imprisonment and he received a full pardon on December 15, 1922.30

Kersh required a second trial because the first jury could not agree. On December 17, 1910, Judge Robert Morrow provided the second jury with a seventeen page "Charge of the Court" that went over all the rules, burden of proof, indictments, definition of murder and of the terms therein, and possible verdicts. ${ }^{31}$ It took the jurors three days to convict Kersh of manslaughter because one juror remained convinced of her innocence. On December 20, 1910, Kersh was found guilty of manslaughter for abetting the murder of Johnson. The jury argued that the motive for the murder was Johnson's $\$ 1900$, though Kersh testified that Johnson "gave her the money in Spokane, Washington, to invest in a

\footnotetext{
28 "Evidence Against Woman Stronger. Both Jesse Webb and Mrs. Kersh Indicted for First Degree Murder."

${ }^{29}$ Duane Hennessy, "Grand Central Murder... A Trunk Mystery," Oregonian, September 15, 1935.

30 George Alexander, "Inquiry Concerning Carrie Kersh," March 13, 1940, OSP Inmate Case Files Box 17 Folder 6362-6381, Oregon State Archives, Salem, Oregon.

31 Robert Morrow, “'Charge of Court,' State of Oregon v. Carrie Kirsh"” (Multnomah County Circuit Court, December 17, 1900), Multnomah County Circuit Court Archives.
} 
lodging house in order that they might receive an income from it."32 Kersh's testimony fell of deaf ears, and on January 5, 1911, Judge Morrow sentenced Kersh to fifteen years in prison. She served seven and a half of her fifteen-year sentence in the Oregon State Penitentiary before she was released on parole on December 14, 1918. Kersh then moved to Idaho to live with family and friends. ${ }^{33}$

Kersh's experience was not unusual. When women planned a murder for gain they frequently elicited help from a man. This is evident in each of the three date ranges in this study. Reasons for the murder could be to improve their legal or financial situation or change their marital condition. In court, the female culprits were largely perceived as accomplices instead of the primary perpetrator, though the murder would likely not have occurred without their bidding. The next two cases feature similar female murderers.

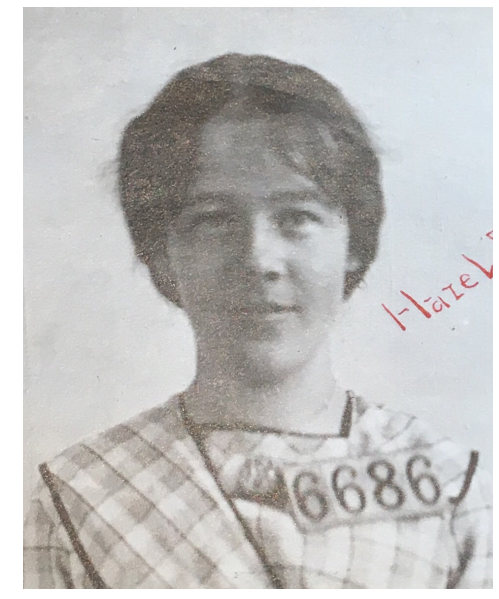

Figure 9. Hazel Erwin, c. 1912. OSP Inmate Case Files, OSA.

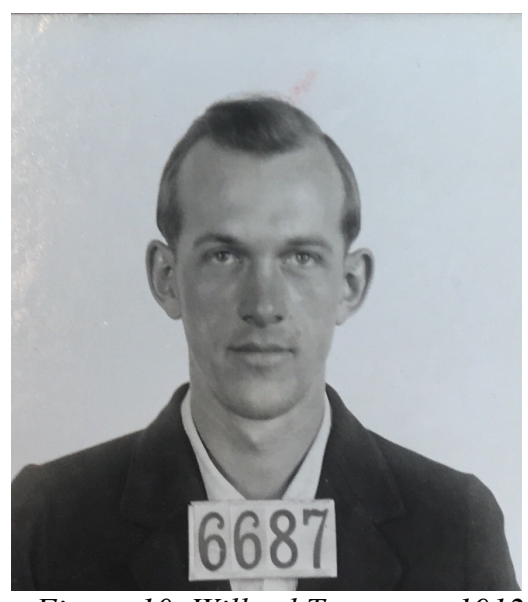

Figure 10. Willard Tanner, c. 1912 OSP Inmate Case Files, OSA.

\footnotetext{
32 George Stenger, “Affidavit, Exhibit 'A”" (1910).; Kersh's attorneys filed a request for a new trial because they claimed they discovered material evidence that the $\$ 1900$ was given to Kersh by Johnson "freely and voluntarily" in Spokane prior to the train ride to Portland. Charles McDonald, who knew Johnson and Kersh in Spokane, stated that the two were very much in love and that Johnson repeatedly stated, "that everything he had in the world belonged to his wife [Kersh], and that she could have it." $\mathrm{He}$ further testified that sometime around June 19,1910, Johnson showed him a roll of greenbacks that he was "going over immediately to give it to his wife" because "she could take care of his money better than he could." The court dismissed the appeal on July 11, 1911, and Kersh was ordered to continue her sentence. 33 Alexander, "Inquiry Concerning Carrie Kersh."
} 
Hazel Erwin and her lover, Willard Tanner, posed as husband and wife when they moved to Portland in the summer of 1912 [Fig. 9 and Fig. 10]. They both had difficulty finding jobs and money was scarce. Against Tanner's wishes Erwin decided that she was going to earn her own money, alluding to prostitution. ${ }^{34}$ Tanner beat her when he found out that she had disobeyed him and was also jealous that she continued to entertain the same man, Ray Wallace. Around 1:00 A.M. on June 19, 1912, Erwin invited Wallace to meet her at a lodging room. Tanner came up from behind and struck Wallace over the head with an iron bar with the intent to steal the keys to the restaurant where Wallace worked. ${ }^{35}$

Erwin left the building and wandered the streets until Tanner found her with their suitcases. Tanner did not think that he had killed Wallace but they later discovered from newspapers that Wallace was dead. ${ }^{36}$ Tanner left Erwin without any money or indication where he was going. She met a young man on the street and asked him to take her to the police station, where she turned herself in. At her trial on June 17, 1912, Erwin was described as "pretty, soft-spoken, and accurate in her grammar and accent, choice in her selection of terms, and with a glint of humor." 37 The court seemed surprised that this woman was involved in a murder. Regardless, she and Tanner were both convicted of manslaughter and given indeterminate sentences of one to fifteen years.

\footnotetext{
34 "Ex-Chorus Girl Is Hazel Erwin. Eye Witness to Wallace Murder Once Frolicked on Barbary Coast," Oregonian, June 28, 1912.

35 "Police Doubt Girl. Officers Think Hazel Erwin Is Shielding Murderer," Oregonian, June 30, 1912.

36 "Ex-Chorus Girl Is Hazel Erwin. Eye Witness to Wallace Murder Once Frolicked on Barbary Coast."

37 "Ex-Chorus Girl Is Hazel Erwin. Eye Witness to Wallace Murder Once Frolicked on Barbary Coast," 15 .
} 
In October 1916, Tanner and Erwin attempted to escape from the Oregon State Penitentiary. Another female inmate imprisoned for manslaughter, Nunnie Williams [p. 54], caught the duo and turned them into the prison matron. Erwin served eighteen years at OSP before her release on June 16, 1930 - three years longer than her indeterminate sentence allowed, likely for her insubordinate behavior. This was the longest imprisonment of any female criminal in Oregon to date. Tanner was paroled ten years before his female accomplice on July $5,1920 .^{38}$

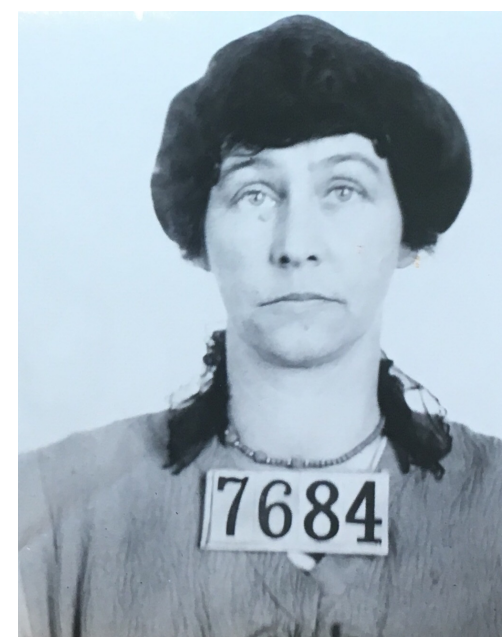

Figure 11. Anna Booth, c. 1916. OSP Inmate Case Files, OSA.

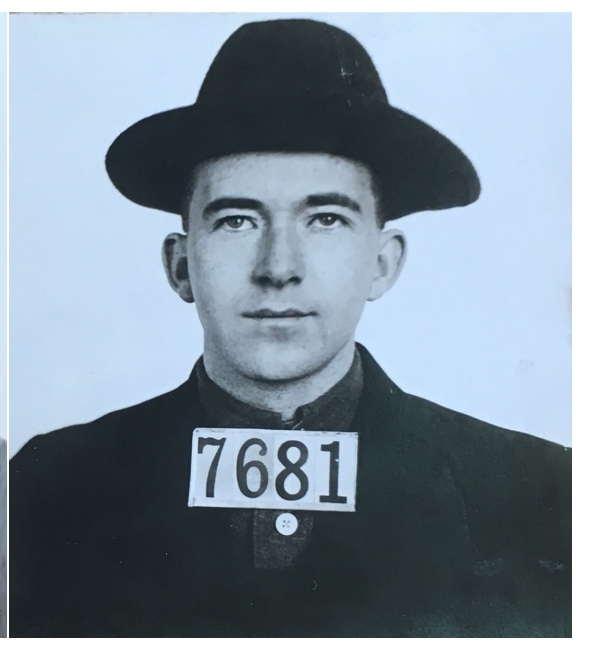

Figure 12. William Branson, c. 1916. OSP Inmate Case Files, OSA.

The third instance in this period in which a woman elicited the help of a man to kill occurred on December 6, 1916. Anna Booth, thirty-two, and William Branson, twenty-three, were convicted of murdering Booth's husband, William Booth. On October 8, 1916, William Booth's corpse was found with bullet wounds from a rifle along the road leading from the town of Willamina to the home of Booth's parents two miles away [Fig. 11 and Fig. 12]. Witnesses stated they saw both Booth and Branson pass along the

\footnotetext{
38 “The Great Register" (Oregon State Penitentiary Records, 1854-1946.), Oregon State Archives, Salem, Oregon.
} 
road where the body was found before and after a shot was heard. Before his death,

William Booth suspected his wife and Branson of having an affair. ${ }^{39}$

Initially, Booth and Branson were tried as co-defendants. Booth's attorney, State

Senator W.T. Vinton, asked the jury to take Branson's young age into consideration. He argued that the state had failed to successfully prove the motive of the crime.

They would have you believe that this man and this woman went into this brush for the purpose of adultery. I suppose - this woman, nearly 33, mother of two little children... all this in full view... and they would have you think that Mr. Booth found them there and they shot him. They would have you believe that 10 or 15 minutes later, after committing these two crimes, Mrs. Booth was going up the road, showing no evidences of emotion. ${ }^{40}$

Senator Vinton was convinced that this respectable wife and mother was incapable of such an act. After twenty-eight hours, the final jury ballots revealed that eight of the jurymen voted for a manslaughter conviction while four held out for an acquittal. They stated that there "was no hope for an agreement" and the judge dismissed the charge. ${ }^{41}$ At her second trial on March 13, 1916, the jury convicted Booth of murder in the second degree. When she heard the verdict she "broke down and cried bitterly."42 The Oregonian stated, "This decision was a complete surprise to all who followed the progress of the trial." 43 Branson was also convicted of second-degree murder and

\footnotetext{
39 “Jury Disagrees in Booth Murder Case. Four Men Hold out 28 Hours for Acquittal," Oregonian, December 8, 1915.

40 "Booth Case Ends; Jury Is Closeted. Circuit Judge Belt Tells Men They Have Nine Forms of Verdict Open," Oregonian, December 7, 1915, 5.

41 “Jury Disagrees in Booth Murder Case. Four Men Hold out 28 Hours for Acquittal," 1.

42 "Convicted Woman Cries Sentence Will Be Pronounced Today upon Mrs. Anna Booth M'Minnville, Or., March 12,” Oregonian, March 13, 1916, 1.

43 “Convicted Woman Cries Sentence Will Be Pronounced Today upon Mrs. Anna Booth M'Minnville, Or., March 12," 1.; Women who were convinced of Booth's innocence pieced patchwork squares together to form a quilt while watching her trial. They charged community members $\$ 0.15$ to have their name embroidered on the quilt. They raffled off the finished product and proceeds went to Booth's defense fund.
} 
sentenced to life in prison. Booth's attorneys appealed the court's decision and a year later on March 9, 1917, Booth pled guilty to the crime of manslaughter instead of standing trial for a third time. She was given an indeterminate sentence of one to fifteen years. Governor Ben Olcott pardoned Branson four years later on September 11, 1920. Booth was also released on parole earlier that year on January 31, 1920, and was "granted full restoration to citizenship" in February $1921 .{ }^{44}$ It is unknown whether the pair reunited after their incarceration.

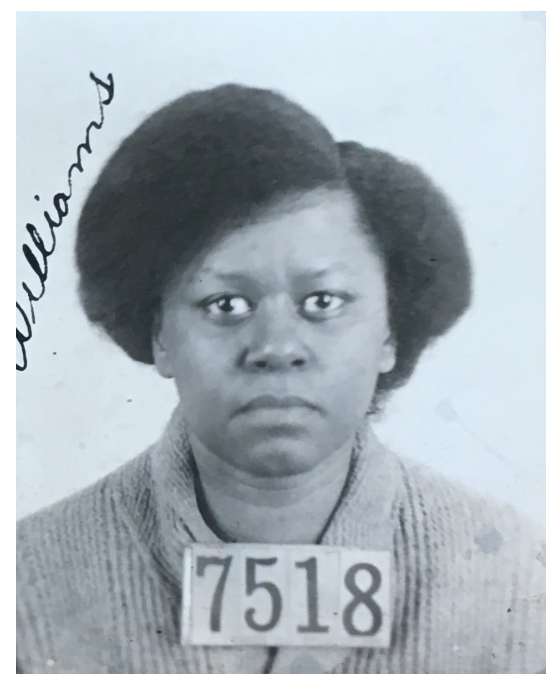

Figure 13. Nunnie Williams, c. 1915. OSP Inmate Case Files, OSA.

Many seemed stunned that Anna Booth was fingered for the murder. Yet the opposite would be true for Nunnie Williams, who was convicted of homicide in January 1916 [Fig. 13]. Because Williams was black and her victim was another black woman, newspapers used the opportunity to poke fun at the case. Newspaper reporters did not seem surprised or offended by Williams's behavior. On December 3, 1915, she was

See Elizabeth Lee Hoffman, "The Murder Quilt: A Methodological Study Exploring Selected Research Methods, Techniques, and Procedures Used to Study Material Culture." (University of Oregon, 1991). 44 J.W. Lewis, "Letter from J.W. Lewis, OSP Warden, to Oregonian Reporter, Duane Hennessy," November 26, 1935, Inmate Case Files Box 25 Folder 7670-7688, Oregon State Archives, Salem, Oregon.; Booth's connection to the state senator may have influenced the governor's decision. 
indicted for the murder of Mildred Hudgins, alias Nitsy Smith. Williams was the second woman in the state to be charged with committing a fatal attack on another woman. ${ }^{45}$ The motive for the dispute was unknown, but Williams claimed it was self-defense because Smith attempted to kill her. However, Williams stabbed Smith with a knife in the back near an open doorway through which she could have escaped.

Melvina Brooks was present at the time of the crime and detained as a material witness in the county jail for forty-six days before Williams's trial. The newspaper chose to print her statements phonetically. When asked where she lived, Brooks said, "Foah Ah came heah Ah lived at 651 Overton street. Now Ah'm with the county," joking that she now lived in the jail. ${ }^{46}$ She said she did not see which woman had the weapon or who had been stabbed but "Theah was blood all ovah de house." 47 She testified that she honestly did not care which one of them had been hurt. Apparently, she was not on agreeable terms with either. After both women ran away from the house screaming, Brooks said she put her hat on and walked home. This is the only case where the Oregonian added elements of "humorous relief" in their coverage of a murder, a testament to perceptions of race during this period. ${ }^{48}$

Williams' self-defense plea did not convince the jury, which convicted her of manslaughter on January 19, 1916. However, the jury requested that she be dealt with mercifully. ${ }^{49}$ The judge sentenced Williams to serve an indeterminate period from one to

\footnotetext{
45 Emma Hannah was the first woman convicted of murdering another woman.

46 "Negress Story Mixed Slayer's Self Defense Plea Suffers on Stand," Oregonian, January 18, 1916, 16.

47 "Negress Story Mixed Slayer's Self Defense Plea Suffers on Stand," 16.

48 "Negress Story Mixed Slayer's Self Defense Plea Suffers on Stand."

49 Adam Diller, "Verdict, State of Oregon v. Nunnie Williams," Pub. L. No. C-5015 (1916).
} 
fifteen years and fined her twenty dollars. ${ }^{50}$ She served exactly two years before she was released on parole on January 25, 1918.

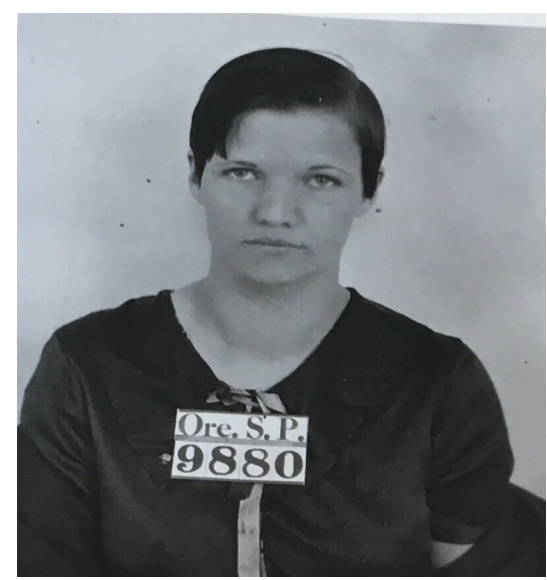

Figure 14. Yvonne Littell, c. 1927.

OSP Inmate Case Files, OSA.

Yvonne Littell's self-defense argument was more convincing [See Fig. 14]. On January 22, 1927, Littell, twenty-one, shot and killed her manager, A. Carl Joslin, at the Portland furniture store where they both worked. She was initially indicted for firstdegree murder without bail. ${ }^{51}$ Littell changed her initial plea from not guilty of firstdegree murder to guilty of manslaughter. She claimed that she shot Joslin in self-defense after he locked the door to the store and sexually assaulted her. During the scuffle he broke three of her ribs and hit her with a stove poker. ${ }^{52}$ It was pointed out in court out that Littell had previously been prosecuted for assault and battery and that she had been addicted to narcotics.

The men of the court seemed more concerned with Littell's prior record and ignored her claim of sexual assault. Littell's court-appointed defense attorney, John

\footnotetext{
50 Diller.

51 “Indictment, State of Oregon vs. Yvonne Littell,” Pub. L. No. C12644 (1927).

52 “Girl Gets Three Years,” Oregonian, May 19, 1927.
} 
Collier, made a motion to have the court appoint a doctor to determine Littell's sanity and mental condition. ${ }^{53}$ The court asked Doctors W.B. Lunsford, S.E. Josephi, and H.W. Williamson of the Mountain View Sanitarium Co. to examine the defendant. ${ }^{54}$ After a "careful and painstaking examination," the doctors concluded that she was "sane and mentally competent to make proper defense in the action in which she is defendant." 55 On May 18, 1927, Littell was sentenced to serve three years in the penitentiary and fined one dollar. ${ }^{56}$ Governor Paul L. Patterson pardoned her two years later on May 19, 1929.

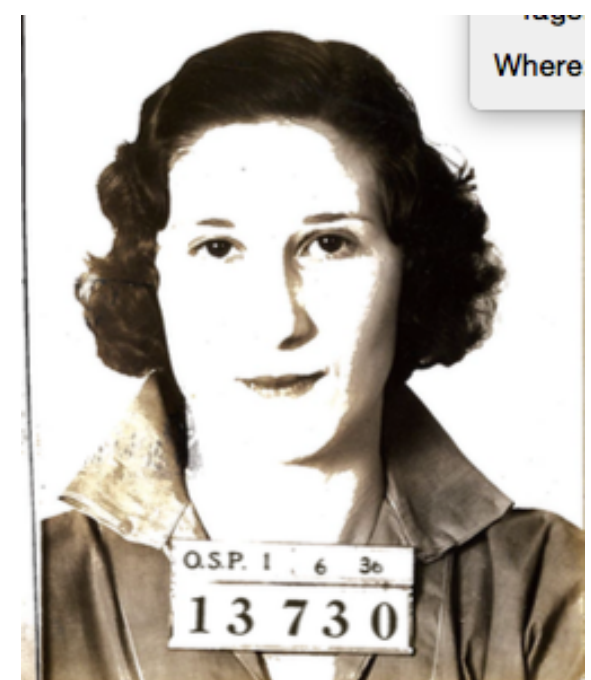

Figure 15. Margaret Hart, January 6, 1930

Oregon Department of Corrections (ODOC) Inmate Case Files, ODOC.

Some cases received more news coverage than others. All that is known of Margaret Hart, twenty-six, was that she killed her husband, Sam Hart, thirty-four, with a paring knife during a drunken dispute on July 7, 1935 [Fig. 15]. Sam Hart had allegedly

\footnotetext{
${ }^{53}$ Louis Hewitt, "Motion, State of Oregon vs. Yvonne Littell," Pub. L. No. C-12644 (1927).

54 Hewitt.

55 W.B. Lunsford, S.E. Josephi, and H.W. Williamson, "Letter to Judge Louis Hewitt from Doctors at Mountain View Sanitarium Co.," May 14, 1927, Multnomah County Circuit Court Archives.

56 “Judgment, State of Oregon vs. Yvonne Littell,” Pub. L. No. C-12644, Judgment No. 13284A (1927).
} 
refused to remain at their Seaside home while Hart was entertaining weekend guests. ${ }^{57}$ Their eight-year-old son, Jackie Hart, was the only person who witnessed the fight. She was indicted for first-degree murder, but the jury must have determined there was enough evidence to merit her actions as self-defense. ${ }^{58}$ At her trial, Hart was charged with manslaughter and released from prison after she completed a one-year sentence. ${ }^{59}$

In the nineteenth century, killing a libertine regularly prompted use of the unwritten law as a defense in court. This argument often, but not always, excused homicide when betrayal served as a motive. But, across the country in the late nineteenth century women's rights activists fiercely argued that the unwritten law defense instigated not-guilty verdicts or reduced sentences and demonstrated the corruption of male-only juries. ${ }^{60}$ Nevertheless, a version of the unwritten law, or a new unwritten law still showed up in court when women were jilted or seduced by men. ${ }^{61}$ A woman who killed a man who wronged her was more justified in exhibiting violent rage.

Prior to 1900, Emma Hannah's case was only instance of a woman committing murder out of jealously, although the victim was the supposed recipient of her husband's affection instead of the husband himself. After 1900 there was a rise in women killing their husbands and boyfriends out of jealously. Those who were jilted or seduced were paroled sooner than others whose crimes stemmed from other motives.

\footnotetext{
57 "Woman to Face Murder Charge," Oregonian, July 9, 1935.; "Woman Charged with Slaying Bound Over," Oregonian, August 2, 1935.; "Woman's Arraignment Due Later This Week," Oregonian, July 11, 1935.

58 Oregonian, September 26, 1935.

59 “Questionnaire of No. 13730,” January 6, 1936, Oregon Department of Corrections.

60 Bakken and Farrington, Women Who Kill Men California Courts, Gender, and the Press, 18.

61 Jeffrey S. Adler, “I Loved Joe, but I Had to Shoot Him': Homicide by Women in Turn-of-the-Century Chicago," The Journal of Criminal Law and Criminology (1973-) 92, no. 3/4 (2002): 877, https://doi.org/10.2307/1144248.
} 


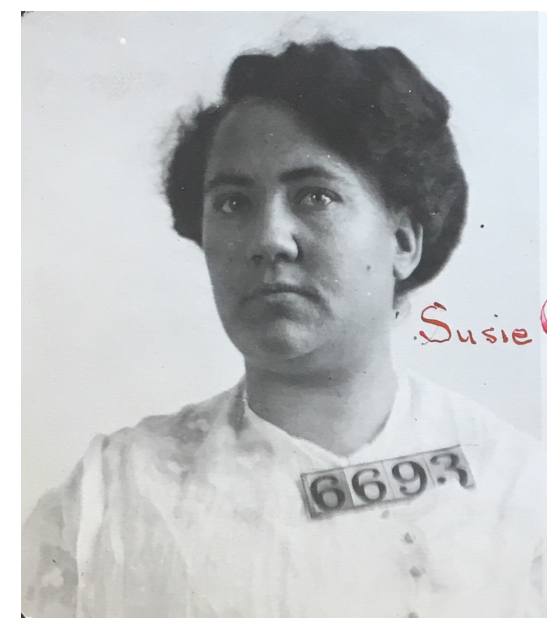

Figure 16. Susie Owens, c. 1912. OSP Inmate Case Files, OSA.

In October 1912, Susie Owens went on trial for the murder of her love interest Charles Celestino [Fig. 16]. On July 12, 1912, Owens claimed that she went to the Celestino family home to meet Celestino for their marriage ceremony. Instead Celestino, his brother, Joseph Celestino, and his father, Pietro Celestino, met her with hostility. ${ }^{62}$ The group argued for a while, and Celestino told Owens that he would not marry her under any circumstances. Owens claimed she blindly fired her gun because Celestino's father and brother were choking and beating her. The bullet hit Celestino in the stomach and killed him. Pietro Celestino testified that he only treated Owens roughly after she had shot his son. ${ }^{63}$

Celestino allegedly enticed Owens into securing a divorce from her husband, $\mathrm{H}$. E. Snyder, and repeatedly promised to marry her. Snyder testified that Celestino ruined his marriage and that Celestino consistently dissuaded Owens from returning home. ${ }^{64}$

\footnotetext{
62 “Jilted Woman Shoots. Italian Is Wounded by Divorcee He Refused to Marry,” Oregonian, July 13, 1912.

63 "Jilted Woman Shoots. Italian Is Wounded by Divorcee He Refused to Marry."

64 "Shot Is Fired Blindly. Susie Owens Says She Did Not Know for Whom," Oregonian, October 10, 1912.
} 
Her diary indicated strong feelings for Celestino as well as her dismay over his refusal to set a wedding date. Additionally, letters between the couple expressed feelings of love as well as threats. ${ }^{65}$

After the shooting, Owens surrendered herself to the county jail. She was indicted and pled not guilty to first-degree murder on July $23,1912 .{ }^{66}$ On October 16, the jury convicted her of manslaughter. She received an indeterminate sentence of one to fifteen years and was ordered to pay a fine of one thousand dollars. ${ }^{67}$ Owens was paroled on March 18, 1914, and sent to a hospital, as she was believed to be dying from a wound she received from her fight with the Celestinos two years prior. ${ }^{68}$ The lack of records after 1914 indicate that she did not return to the penitentiary.

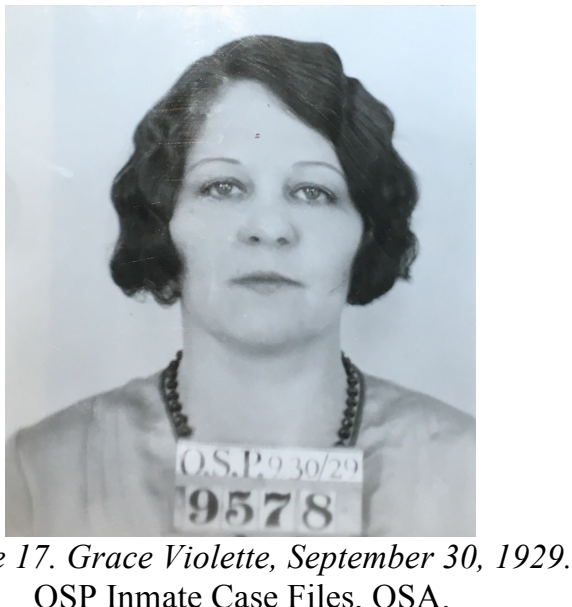

On March 3, 1926, Grace Violette found her boyfriend, Henry Isaacson, with another woman in their shared home [Fig. 17]. Violette stated that, later in the evening, when she questioned Isaacson about his fidelity, he threatened to kill her. Violette argued

65 "Shot Is Fired Blindly. Susie Owens Says She Did Not Know for Whom."

66 "Indictment, State of Oregon vs. Susie Owens," Pub. L. No. C-2658 (1912).

67 “Judgment, State of Oregon vs. Susie Owens,” Pub. L. No. C-2658, Judgment No. 50050 (1912).

68 "Susie Owens Is Paroled. Woman Who Killed Fiance Said to Be Dying from Old Wounds," Oregonian, March 23, 1914. 
that she then shot four or five rounds into Isaacson's body in self-defense. She was initially indicted for first-degree murder but instead pled guilty to manslaughter. Her indictment stated that she used both "a pistol and revolver" to shoot Isaacson. ${ }^{69}$ To most, the fact that Violette used two separate weapons would indicate that the murder was not in self-defense. However, Deputy District Attorney Hammersley told the court that there were "some mitigating circumstances in the woman's favor" and thus he accepted her guilty plea to the lesser charge. ${ }^{70}$ At her trial on May 19, 1926, the court sentenced her to five years in the penitentiary and ordered her to pay a fifty-dollar fine. ${ }^{71}$ She was released after serving three years of her sentence on September 30, 1929, and likely went to live with a friend in Salem. ${ }^{72}$

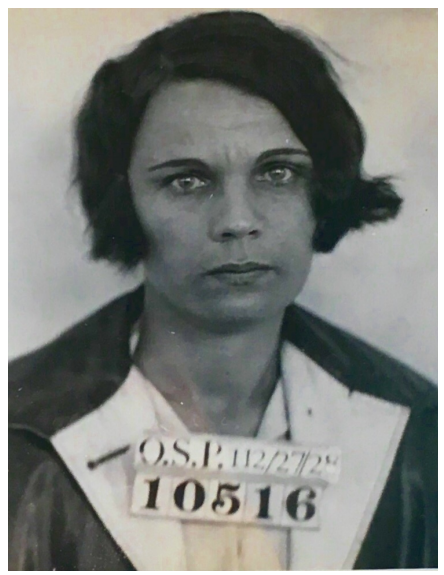

Figure 18. Doreene de Selva, December 27, 1928. OSP Inmate Case Files, OSA.

On November 8, 1928, Doreene de Selva shot and killed her estranged lover Gilbert J. Pinto with a revolver on board the steamship where he worked [Fig. 18].

\footnotetext{
69 "Indictment, State of Oregon vs. Grace Violette," Pub. L. No. C-12036 (1926).

70 "Woman Slayer Guilty," Oregonian, May 25, 1926.

71 “Judgment, State of Oregon vs. Grace Violette," Pub. L. No. C-12036, Judgment No. 7310A (1926).

72 Christine Latourell, "Letter from Christine Latourell to OSP Superintendent, H.W. Meyers," August 23, 1927, Inmate Case Files Box 39 Folder 9559-9579, Oregon State Archives, Salem, Oregon.
} 
Thirty-two-year-old de Selva was destitute and desperate when she went to confront Pinto about their strained relationship. Police indicated that the murder seemed planned, but she maintained that she intended to commit suicide in front of him. When Pinto turned away from her laughing at her threat of suicide, she shot him instead. ${ }^{73}$

A week later de Selva was indicted for murder in the first degree for killing Pinto "unlawfully and feloniously, purposely and of deliberate and premeditated malice." 74 At her trial on November 27, 1928, de Selva was emotionally distraught and overcome with incessant crying. She fainted after she was informed Pinto had died from his wound, and she was placed in the hospital to rest. These stereotypical feminine behaviors of crying and fainting later influenced the jurors' decision to request leniency for de Selva. The next day she pled not guilty of first-degree murder.

The Oregonian contended that the courtroom was full of female spectators wondering whether de Selva would be the first woman in Oregon to face the death penalty. ${ }^{75}$ After 1900, Oregon women became a larger presence at trials, especially trials that involved female defendants, and newspapers regularly commented on their numbers. ${ }^{76}$ Even so, during this period women were still segregated to one side of the bar. Generally in the United States, courts resisted women serving on juries, on the grounds that they had a superior obligation to serve their husbands. Others argued that women jurors could help eliminate corrupt verdicts, especially in cases with female defendants. Though Oregon women received the right to vote in 1912, the process to

\footnotetext{
73 "Charge of Murder Faced by Woman," Oregonian, November 10, 1928.

${ }^{74}$ Stanley Meyers, "Indictment, The State of Oregon vs. Doreene de Selva," Pub. L. No. C14214 (1928).

75 "Charge of Murder Faced by Woman."

76 "Woman Slayer in Court," Oregonian, November 21, 1928.
} 
gain full citizenship, which included serving as jurors, can best be understood as "a second suffrage campaign," that was still being contested during de Selva's trial in $1928 .{ }^{77}$

The attention that the trial received likely saved de Selva from a more serious conviction. Instead of receiving the death penalty, the jury found her guilty of manslaughter. On the official, typed verdict the jury foreman wrote, "with recommendation for leniency." 78 De Selva was sentenced to a maximum of five years in the penitentiary and fined five-dollars. ${ }^{79}$ She was sent to OSP where women's accommodations were still more or less temporary. ${ }^{80}$ Prior to 1930 , female inmates at the penitentiary were maintained in one large room in the second story of the chapel. During her imprisonment de Selva shared this room with five other women charged with manslaughter and several others convicted of lesser crimes. ${ }^{81}$

In some of cases during the 1901-1935 period, it was evident that the jurors' decision to convict defendants of manslaughter was a more lenient choice compared to the opinions of the Parole Board. After less than a year in prison the Parole Board reviewed de Selva's sentence. Reports submitted to the State Parole Board by Judge R. Morrow, the judge in her case, stated that "the jury were clearly influenced by her [de

${ }^{77}$ Linda K. Kerber, No Constitutional Right to Be Ladies (New York: Hill and Wang, 1998), 143.

78 Dell Webb, "Verdict, The State of Oregon vs. Doreene de Selva," Pub. L. No. C-14214 (1928).

79 Robert Morrow, "Trial Order, The State of Oregon vs. Doreene de Selva," Pub. L. No. C-14214 (1928).

80 Many western states did not have gender separate penitentiaries until the 1960s. Oregon's first all female prison was built in 1965; Jessica Rondema, "Oregon State Penitentiary," accessed March 19, 2018, https://oregonencyclopedia.org/articles/oregon_state_penitentiary/\#.Wq8TfZPwZsM.

81 During the day inmates had natural light and heat, and at night they were transported into solitary compartments divided by wooden partitions; See Diane L. Goeres-Gardner and John Ritter, Oregon State Penitentiary (Charleston, South Carolina: Arcadia Publishing, 2014). Though this is not a peer-reviewed source, the book was co-authored by John Ritter who worked various positions at OSP for thirty years. I utilized this source for its short section that described the OSP women's ward prior to and after 1930. 
Selva's] appearance," despite the judge's opinion that she had committed a premeditated murder. Judge Morrow also commented that "she [de Selva] was reeking of syphilis" and that the court took precautions to keep her from handling anything. ${ }^{82}$ He concluded:

Personally, I think the young woman has been in the habit of giving way to her feelings and behaving like a spoiled child throughout her life and never has had any idea of responsibility for her conduct, or that there existed such a thing in the world as not having her own way. ${ }^{83}$

Judge Morrow did not recommend parole. The district attorney agreed with the judge, stating that de Selva was guilty of second-degree murder and her actions did not merit parole. ${ }^{84}$ After spending three and a half years in prison, she was paroled on April 25, 1932. One source stated that De Selva committed suicide by jumping off the St. Johns Bridge in Portland on May 3, $1933 .{ }^{85}$

While de Selva was in prison, the state expanded the women's ward. In 1930, OSP constructed a new four-story reinforced concrete administrative building with the second and third stories housing female prisoners. De Selva was the first female murderer to serve time in the newly appointed women's ward. Up until this point Oregon was nearly half a century behind the rest of the nation in terms of the evolution of female correctional institutions. The 1930 renovation demonstrates that the state had finally

\footnotetext{
82 Robert Morrow, "Report to Parole Board, State of Oregon, Statement of Judge," August 5, 1929, Inmate Case Files Box 49 Folder 10516-10519, Oregon State Archives, Salem, Oregon.; This comment alluded to the possibility that de Selva was involved in prostitution. More likely this was a racist remark.

83 Morrow.

84 The fact that the district attorney and judge made this comment in the parole review indicates that they did not agree with jury's decision to charge de Selva with manslaughter.

85 Goeres-Gardner, Murder, Morality and Madness: Women Criminals in Early Oregon, xv.
} 
come to terms with the fact that the number of female criminals continued to rise each year and that inmates required more appropriate accommodations. ${ }^{86}$

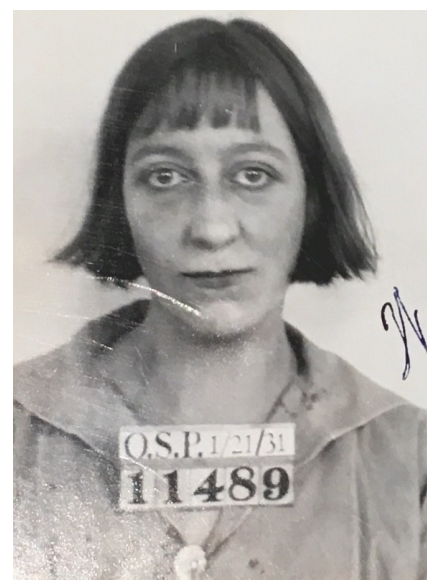

Figure 19. Ruth Warnock, January 21, 1931. OSP Inmate Case Files, OSA.

Similar to the murder committed by de Selva, Ruth Warnock fatally shot John Schwer in a Marshfield hotel in October 1930 [Fig. 19]. Warnock and Schwer were involved in a romantic relationship for several months, and she was irate when he left her. ${ }^{87}$ The state held that the motive for killing Schwer was jealously. ${ }^{88}$ On January 15 , 1931, the jury convicted Warnock of manslaughter, and the judge sentenced her to serve seven years in the penitentiary. Although she was described in her penitentiary case file as "emotionally unstable" and "high strung," Judge J.T. Brand recommended that she

\footnotetext{
86 The matron lived on the second floor with her warden husband. This floor also contained the kitchen, laundry, dining room, and women's work area. The third floor consisted of the assistant matron's rooms, the sleeping quarters that accommodated forty inmates, bathrooms and a surgery; See Goeres-Gardner and Ritter, Oregon State Penitentiary.

87 "Woman Gets 7 Years," Oregonian, January 20, 1931.

88 "Woman Who Slew Ex-Friend Convicted," Oregonian, January 16, 1931.
} 
receive a chance at parole. Warnock was released on parole after four and a half years on September 21, 1935. ${ }^{89}$

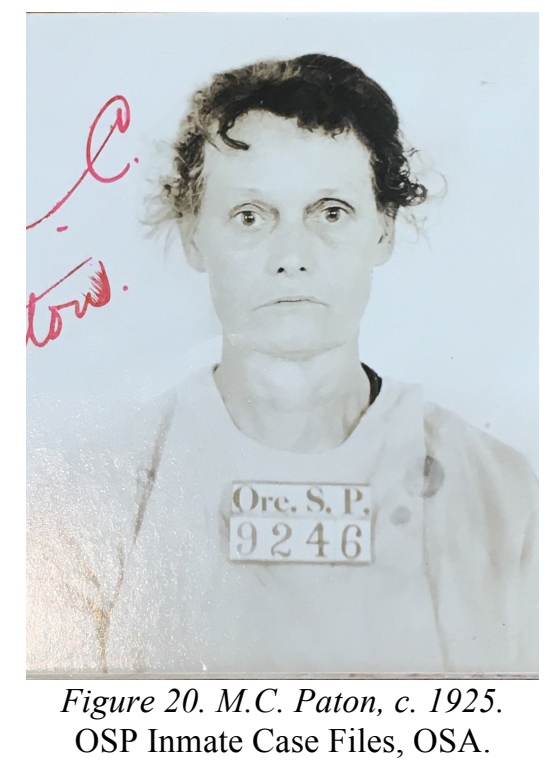

Some cases in this period align with today's understanding of manslaughter, but the next two cases of filicide fall outside that realm of understanding. Filicide is the murder of a one's child or young relative, distinguished from infanticide, the murder of a child less than one year old. In cases of filicide, perpetrators often argued that they killed the child to protect them against the larger threat of a painful or dismal future. ${ }^{90}$ At other times it was simply because the child was disobedient.

On April 21, 1925, fifty-nine-year-old M.C. Paton whipped her four-year-old granddaughter, Silva Deschamps, to death with a heavy harness strap [Fig. 20]. Deschamps lived with her mother and three siblings on Paton's small ranch in Tillamook County. Neighbors had previously called the police out to the ranch several times

\footnotetext{
89 “Oregon State Penitentiary Inmate Case File \#11489, Ruth Warnock," Box 59 Folder 11482-11489. Oregon State Archives, Salem, Oregon..

90 Adler, "I Loved Joe, but I Had to Shoot Him," 873.
} 
alleging child cruelty, but the police stated that there was little physical evidence to prove abuse. Moreover, Paton had threatened the same neighbors with a gun on numerous occasions. ${ }^{91}$ When the police were called again on April 21, they found Dechamps, "black and blue all over" with "no spot as large as one's hand upon the body which had not marks and abrasions [sic]."92 The autopsy revealed over a hundred, "Livid welts marred the face of the golden-haired child... and [her] chubby arms were but a mass of purple flesh."93 The cause of death was a severely lacerated kidney. Additionally, Deschamps had been "strung up by cords suspended from the rafters in a bedroom, the cords being attached to the thumbs of the child with her feet barely resting on the floor."94 Paton tried to excuse the use of force stating that Deschamps was disobedient and physically aggressive toward her. She claimed that she was only protecting herself against Deschamps" "meanness" and did not intend to hurt the child. ${ }^{95}$ During her trial Paton's mental condition and age were taken into consideration. She was permitted to plead guilty to manslaughter instead of receiving a first- or second-degree murder conviction and was sent to OSP on May 4, 1925.

In the Parole Board's July 3, 1928 report, District Attorney C.W. Barrick stated that Paton should remain in prison for the rest of her life, but that he would settle on her

\footnotetext{
91 "Threat to Kill Heard at Inquest," Oregonian, April 24, 1925.

92 C.W. Barrick, "Statement of the Crime as Part of the Report to Parole Board," July 3, 1928, Inmate Case Files Box 37 Folder 9231-9246, Oregon State Archives, Salem, Oregon.

93 “Threat to Kill Heard at Inquest."; "Killer of Child Indicted by Jury," Oregonian, April 26, 1925.

94 Barrick, "Statement of the Crime as Part of the Report to Parole Board."

95 "Threat to Kill Heard at Inquest."
} 
serving the maximum fifteen years. ${ }^{96}$ Paton served ten years of her indeterminate sentence before she was released in May 1935 on good behavior and sent to live with one of her daughters in Coos County. A letter dated August 17, 1935, from District Attorney A.E. Hagglund of Tillamook County to the OSP warden inquired about Paton's behavior and mental condition while she was imprisoned. Hagglund stated that Paton's daughter in Coos County planned to send her mother back to Tillamook County because she "does not want her and is afraid to leave her with her children."97 The warden responded:

It is quite probable that if you will have her examined as to her mental condition, that the examining physician would recommend that she be placed in some institution where she would be able to receive treatment suitable to her needs. ${ }^{98}$

One cannot blame Paton's daughter for the distrust she felt toward her mother. It is unknown if Paton's family followed up with the warden's recommendation to consult a physician and place her in an institution.

\footnotetext{
96 C.W. Barrick, "Report to Parole Board," July 3, 1928, Inmate Case Files Box 37 Folder 9231-9246, Oregon State Archives, Salem, Oregon.

97 A.E. Hagglund, "Letter from District Attorney, A.E. Hagglund, to OSP Warden, J.W. Lewis," August 17, 1935, Inmate Case Files Box 37 Folder 9231-9246, Oregon State Archives, Salem, Oregon.; It is uncertain why Paton was never moved to the state hospital if she was mentally ill. After the first period of study between 1854 and 1900, several women received mental health evaluations by medical professionals but were not sent to Oregon State Hospital.

98 J.W. Lewis, "Letter from OSP Warden, J.W. Lewis to District Attorney, A.E. Hagglund," August 21, 9135, Inmate Case Files Box 37 Folder 9231-9246, Oregon State Archives, Salem, Oregon.
} 


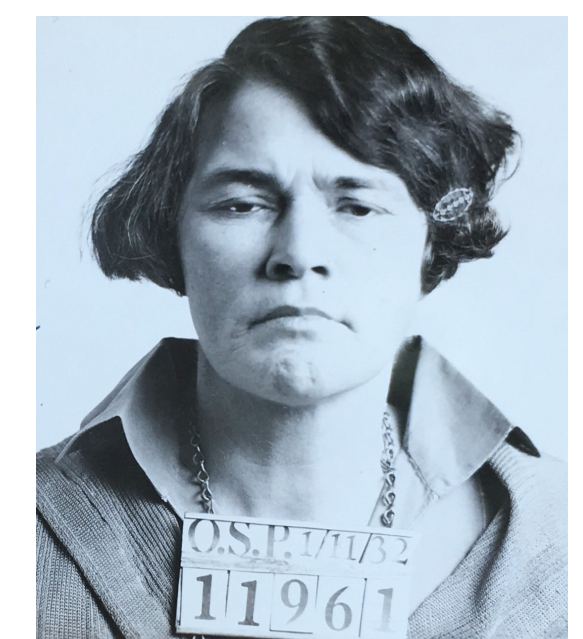

Figure 21. Laura Potts, January 11, 1932.

OSP Inmate Case Files, OSA.

Laura Potts committed the second case of filicide by a female defendant [Fig. 21].

On October 4, 1931, Potts, forty-two, shot and killed her nine-year-old daughter, Isabel Potts, while they lay in bed together at their home in Gales Creek. She then turned the gun on herself but was unsuccessful in committing suicide. In the incident report Potts explained the reason she killed her daughter was that "there had been a great deal of immorality" between Isabel Potts, her brothers, and the neighbor children, and she feared that her daughter was "ruined." 99 These events combined with the family's dismal living conditions caused Potts great distress and depressed thoughts. Additionally, medical examiners at the Oregon State Hospital determined that she was a "high grade moron" who was probably insane at the time of the shooting. 100 On January 11,1932 , she received an indeterminate sentence of one to fifteen years for committing manslaughter.

\footnotetext{
99 Court Officials of Washington County, “Observations of Officials and Record of Discipline,” 1931, OSP Inmate Case Files Box 59 Folder 11482-11489, Oregon State Archives, Salem, Oregon.

100 Evans, "Mental Examination by Dr. Evans at Oregon State Hospital," January 13, 1937, OSP Inmate Case Files Box 64 Folder 11959-11969, Oregon State Archives, Salem, Oregon.
} 
After serving eight years she moved back in with her husband and other children on February 5, 1940.101

Potts' case is similar to that of M.C. Paton. Both women were found to suffer from some form of mental incapacity or imbalance. Potts spent just over eight years in prison and Paton served ten. Both women were released back into their families' care where they had renewed contact with children. They differ in that Potts seemed to want to end both her daughter's and her own life. She was worried for her child's future. Paton, in contrast, violently beat her granddaughter to death and then argued it was selfdefense. Though both cases involved filicide, the intent behind them was very different. Even so, jurors convicted both women of manslaughter and judges sentenced them to no more than fifteen years behind bars.

\section{Conclusion}

Indeterminate sentencing and the parole system as a means to rehabilitation was part of Progressive Era reform in Oregon. Like other aspects of the progressive drive for efficiency, indeterminate sentencing was promoted to eradicate vice and crime. ${ }^{102}$ After the turn of the twentieth century the notion that criminals should be rehabilitated instead of punished gained adherence from state officials and prison administrators. ${ }^{103}$ As such, women murderers were sometimes given a more lenient sentence than the crime deserved, but the leniency associated with indeterminate sentences in principle was in practice inconsistent and sometimes punitive. Compared with women murderers in the

\footnotetext{
101 Paul Kelly, "State Board of Parole and Probation Release Document," January 25, 1940, OSP Inmate Case Files Box 59 Folder 11482-11489, Oregon State Archives, Salem, Oregon.

102 Joseph E. Laythe, Crime and Punishment in Oregon, 1875-1915: A Study of Four Communities (The Edwin Mellen Press, 2008), 16.

103 Laythe, 42.; The Oregon Boot fell out of use by 1939.
} 
nineteenth century, women convicted of manslaughter between 1901 and 1935 spent a longer time in prison, an average of four years more than the previous period [Table 2]. Several of the terms these women served seem arbitrary relative to their crimes, indicating that indeterminate sentencing did not necessarily lead either to a just punishment or rehabilitation.

Social and legislative changes affected how female murderers were treated in the courtroom and prison. Between 1901 and 1935 every women accused of homicide was convicted of manslaughter, even when the circumstances of the case suggested otherwise. Court records and case files make it clear that, in cases where the judge or district attorney were convinced that the defendant was guilty of first- or second-degree murder, jurors voted for the lesser manslaughter conviction. Though these male jurors likely understood that some of these defendants committed premeditated murder, they never agreed to issue a more severe conviction than manslaughter.

Oregon women's role in progressive reform, especially but not only the suffrage movement, challenged both patriarchy and gender-defined spheres. These challenges perpetuated debates about the sameness and difference between men and women. Indecisiveness regarding women's voting rights and jury duty was also reflected in jurors' decisions to charge female defendants with manslaughter. It was a safe choice in a time when the nature of women and their roles were not clearly defined. These juries' decisions demonstrate that women were still understood as inherently different from men. 
Chapter 3: 1936-1950

The years between 1936 and 1950 marked a significant transformation in the perception of female criminals, not least women who kill. Of the seven women found guilty of murder during these years, two were the first women in Oregon history convicted of first-degree murder, another two of second-degree murder and only three of manslaughter [Table 5]. This differs significantly from the previous period in which every woman was convicted of manslaughter.

\begin{tabular}{|c|c|c|c|c|c|c|}
\hline Name & Conviction & Date & Sentence & Arrival & Release & Years \\
\hline Agnes Ledford & Murder 1 & $9 / 4 / 37$ & Life & $6 / 6 / 38$ & $8 / 17 / 56$ & 18.17 \\
\hline Julia Carlson & Murder 2 & $12 / 19 / 40$ & Life & $4 / 21 / 41$ & $8 / 6 / 1948$ & 7.25 \\
\hline Martha Vernon & Manslaughter & $5 / 31 / 46$ & $\begin{array}{c}2 \text { years } \\
\text { parole }\end{array}$ & N/A & N/A & N/A \\
\hline Luella Henagin & Murder 2 & $10 / 29 / 46$ & Life & $12 / 11 / 46$ & $12 / 11 / 53$ & 7 \\
\hline Gladys Broadhurst & Murder 1 & $10 / 14 / 46$ & Life & $3 / 27 / 47$ & $7 / 27 / 56$ & 9.33 \\
\hline Helen Rookard & Manslaughter & $8 / 17 / 47$ & 10 years & $11 / 5 / 1947$ & $9 / 22 / 1951$ & 3.75 \\
\hline Atlee Chaboude & Manslaughter & $8 / 26 / 50$ & 10 years & $11 / 20 / 1950$ & $3 / 24 / 54$ & 3.33 \\
\hline
\end{tabular}

Table 5. Defendants 1936-1950

The first homicide committed by a woman in this period occurred in 1937, when Agnes Ledford was convicted of first-degree murder. The years surrounding World War II further contributed to how women perceived themselves and their abilities. Men also observed this shift, as women became a force in the public sphere. For example, though Oregon women received the right to serve on juries in 1921, court records and newspapers do not reference their involvement in felony trials until the mid-1930s. In this chapter I argue that women jurors were a key factor behind the first convictions of women for first-degree murder. It is important to note that this claim is based on a small data set and may be strengthened with further examination into acquitted murder cases, or 
other felony trials in which women served as jurors for female defendants. Since this period includes all three classifications of homicide - manslaughter, second-degree, and first-degree murder - the chapter is organized accordingly.

Manslaughter Convictions, 1936-1950

The three women charged with manslaughter between 1936 and 1950 shot and killed a significant other or employer during heated arguments and claimed self-defense against a man's abuse. The plea of self-defense was designed to benefit the reasonable man or woman who acted out of necessity to protect themselves from immediate danger. During this period in Oregon, sentences for manslaughter varied between one and fifteen years, a continuation of indeterminate sentencing initiated during the Progressive Era.

The first of the three manslaughter convictions occurred in 1946. On May 31 of that year, Martha Jane Vernon, twenty-four, claimed she mistakenly shot Augustus Gerald Garrett, thirty-eight, during a scuffle in his pickup truck. ${ }^{1}$ The "Modern Probation Act" passed in 1931 granted courts the authority to parole any defendant convicted of a crime before they went to the penitentiary. ${ }^{2}$ This diverged from the previous probation act, which required a person convicted of manslaughter to serve a minimum of one year in the penitentiary before being released on probation. Vernon's case is the only one that aligns with the new act. In lieu of prison time she received two years of parole. ${ }^{3}$

\footnotetext{
1 "Woman Indicted in Man's Death," Oregonian, June 22, 1946, 9.; Vernon was the second black woman in Oregon to be convicted for homicide.

2 "Board of Parole and Post-Prison Supervision Administrative Overview December 2006," 2.

3 This is the reason why Martha Jane Vernon does not have mug shot on file.
} 


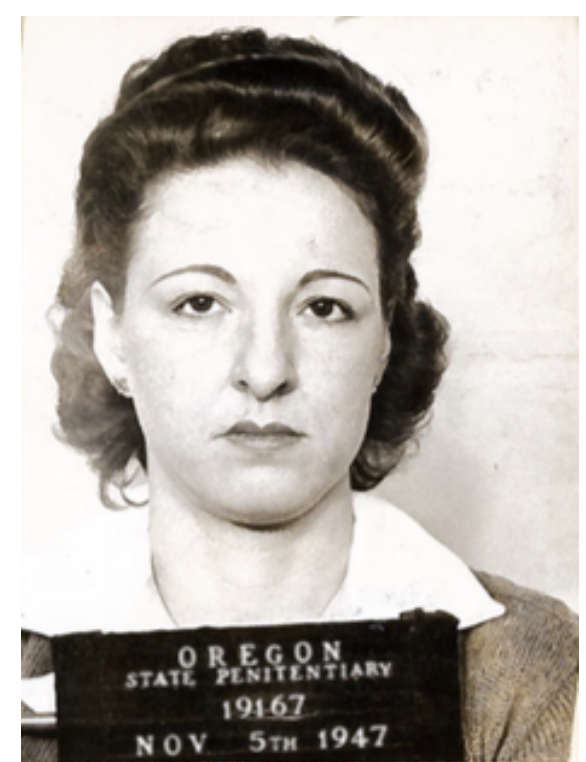

Figure 22. Helen Rookard, November 5, 1947.

ODOC Inmate Case Files, ODOC.

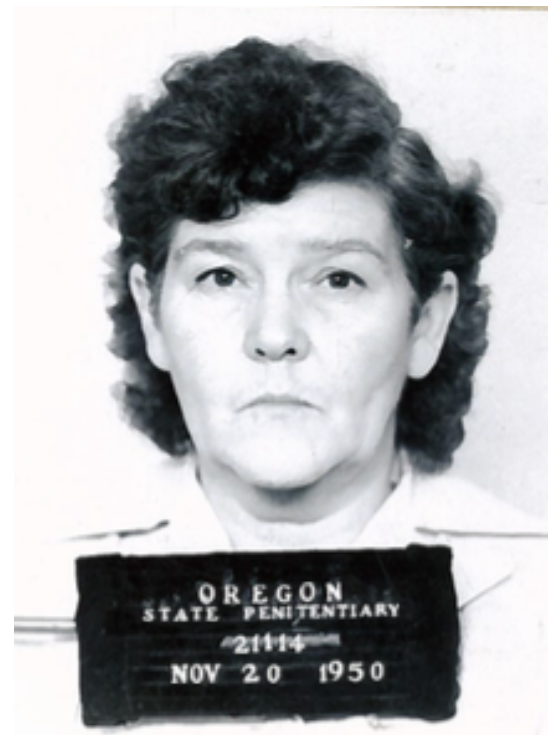

Figure 23. Atlee Marie Chaboude, November 20, 1950. ODOC Inmate Case Files, ODOC.

The next two women convicted of manslaughter also shot their abusers in selfdefense. On August 14, 1947, Helen Rookard, twenty-nine, killed her abusive logger husband, Walter Rookard, after he discovered she was in a sexual relationship with a neighbor [Fig. 22]. Rookard was sentenced to a ten-year term in prison and fined five hundred dollars. ${ }^{4}$ She was released on parole after four years. Lastly, on August 26, 1949, Atlee Marie Chaboude, fifty-three, shot her employer, Curtis Kandle, fifty-eight, on his farm where she worked as a housekeeper [Fig. 23]. Chabaude claimed that she used the gun in self-defense as Kandle regularly threatened to kill her. ${ }^{5}$ She was sentenced to serve no more than ten years and was released on parole after three and a half years.

\footnotetext{
4 “10-Year Term Given Woman," Oregonian, November 6, 1947, 10.

5 “Jury Decides Woman Guilty,” Oregonian, November 16, 1950, 14.
} 
These three manslaughter cases received very little coverage in newspapers and each woman served four years or less for her crime. Those who committed crimes that warranted a longer sentence were covered extensively in the news. Gender roles informed cautionary tales in the media. Periodicals reprinted the comparative character references that prosecuting attorneys used to describe defendants. Newspapers portrayed first-degree murderer Gladys Broadhurst as a greedy and scheming woman who took advantage of the livelihoods of at least two of her husbands and ordered the murder of a third [p. 84]. Reporters directed attention to her "marital adventures" and the fact that she was married and divorced several times. ${ }^{6}$ The district attorney in Agnes Ledford's first-degree murder case branded her "a modern day De Medici," alluding to the sixteenth-century Italian noble Catherine de Medici's desperate attempts to keep her sons on the throne through excessive persecutions and massacres [p. 81]. ${ }^{7}$ Others called her a "Borgia," referring to the noble Renaissance family known for its use of arsenic to poison enemies. ${ }^{8}$ Prosecuting attorney Blaine Hallock described Broadhurst as a contemporary "Lady Macbeth," a wife who ceaselessly encouraged her husband to murder. ${ }^{9}$ Prosecuting attorneys described second-degree murderer, Luella Henagin, as a "cool, phlegmatic, steely type of woman [p. 75]." 10 Nearly every article written about the case and trial emphasized that she showed little emotion and alleged that jealousy was the obvious motive for her attack.

\footnotetext{
6 Ron Moxness, “Suspect Wed Seven Times,” Oregonian, February 25, 1947, 36.

7 “Accused Poisoner Attends Hymnals," Oregonian, November 1, 1937, 9.

8 Herbert Lundy, "When Justice Triumphed: The Ledford Murder," Oregonian, September 11, $1938,89$.

9 Ron Moxness, "Prosecutor Tells Jury Lurid Story," Oregonian, February 28, 1947, 1.

10 “Prisoner Seen Cool Type," Oregonian, December 8, 1946, 21.
} 


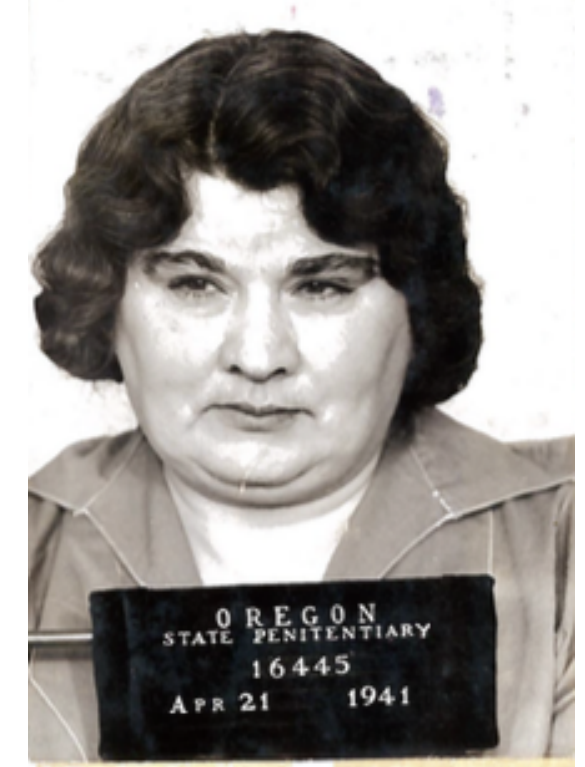

Figure 24. Julia Carlson, April 21, 1941. ODOC Inmate Case Files, ODOC.

The phrase, "Hell hath no fury like a woman scorned," immediately comes to mind when examining Julia Carlson's case [Fig. 24]. Paul Notzold, fifty-two, invited his estranged wife, Martha Notzold, to visit him in Portland in December 1940. She operated a ranch outside of Battle Ground, Washington, and only saw her husband periodically. A couple days later, on December 19, Portland police found Notzold's mutilated body in a blood soaked bed in the home of his girlfriend, Julia Carlson, age fifty. Carlson herself was incoherent and passed out drunk on her kitchen floor. She admitted under questioning that she was overwhelmed by jealous rage at the thought of Notzold and his wife reigniting their relationship. ${ }^{11}$ On the evening of December 17, 1940, hours after Martha Notzold left Portland to return home, Carlson persuaded Notzold to drink heavily

11 "Woman Held in Ax Death," Oregonian, December 20, 1940. 
and coerced him into bed. Early the next morning she hit him on the right side of his head with the blunt edge of a hand ax and slashed his throat and wrists with a straightedge razor. ${ }^{12}$ Both weapons were found near the murder scene. Carlson said she also intended to commit suicide but became too nervous to carry out her plan.

On December 20, 1940, Carlson was indicted by the Multnomah County grand jury on one count of first-degree murder. ${ }^{13}$ The night before her trial she told her attorneys, Pat Hannon and Lou Wagner, that she wished to change her plea from not guilty of first-degree murder to guilty of second-degree murder. Against their advice, she changed her plea. Circuit Judge Alfred P. Dobson sentenced her to mandatory life in prison. ${ }^{14}$

The Oregonian made sure to note that Carlson showed no emotion when her sentence was pronounced..$^{15}$ The physical nature of the murder ensured that there were no claims of femininity to hang onto. Unlike the rest of the women convicted of homicide between 1936 and 1950, reporters did not interview the jurors or provide information about witnesses or character reference testimonies. This case also differs in that Carlson pled guilty to the murder whereas others maintained their innocence. Though Carlson received a life sentence, she was released on August 6, 1948, seven and a half years after her conviction. Records in her case file stated that she was discharged from parole on October 28, 1957.16

\footnotetext{
12 "Woman Held in Ax Death," 6.

13 "Woman Indicted in Death Case," Oregonian, January 4, 1941, 8.

14 "Woman Enters Guilty Plea," Oregonian, April 22, 1941, 6.

15 "Woman Enters Guilty Plea," 6.

16 L.H. Mallet, “Discharge of Parole and Probation,” October 28, 1957, Oregon Department of Corrections.
} 


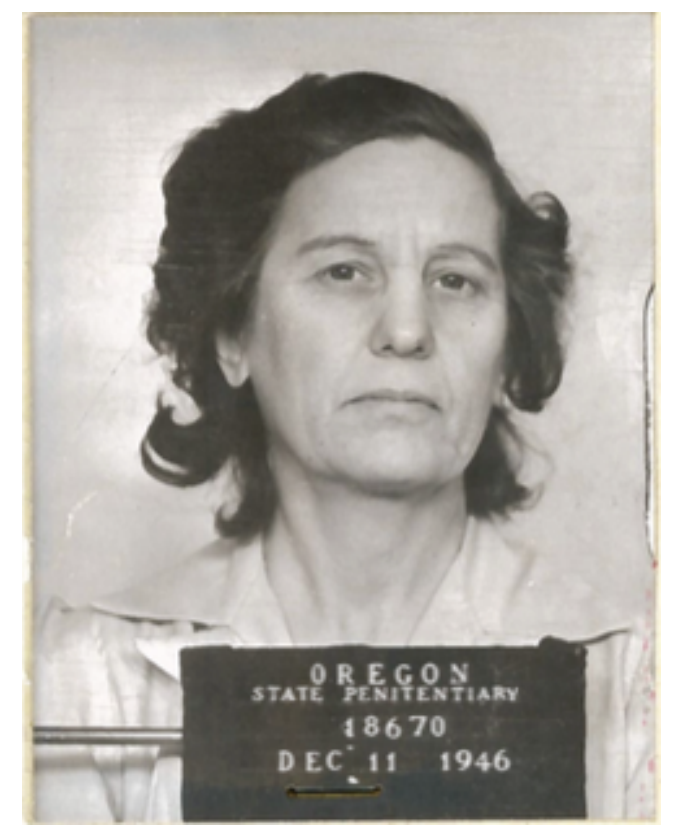

Figure 25. Luella Henagin, December 11, 1946.

ODOC Inmate Case Files, ODOC.

The other second-degree murder between 1936 and 1950 took place in West Linn six years after Carlson's trial. It involved another jealous woman, Luella Henagin, fortyfive, who shot her husband, Robert L. Henagin, forty-two, on the night of October 28, 1941 [Fig. 25]. ${ }^{17}$ Henagin maintained that the shooting occurred during a struggle inside the family car between herself and Robert Henagin over the possession of a .22-caliber pistol. The quarrel occurred after her husband, the West Linn School Superintendent, came home late from a PTA meeting. Just after midnight, he drove himself to a hospital and called Chief Deputy Sheriff Joe Shobe. "Joe, this is Bob Henagin. My wife just shot me twice in the back. I got the gun from her and threw it into the brush. Please go to my home right away. I am afraid she might harm the children."18

\footnotetext{
17 “State Completes Case in Principal's Slaying," Oregonian, December 6, 1946, 8.

18 "State Completes Case in Principal's Slaying," 8.
} 
When Chief Deputy Shobe arrived at the family's home Henagin asked him what was wrong and why there were so many officers with him. Shobe asked where her husband was and Henagin said she had not seen him since he left for the PTA meeting at 7:30 P.M. She then stated that she had only left the house for a few minutes that evening to visit a neighbor. Shobe told her that her husband had been shot and was in critical condition at the hospital. He told Henagin that she must come with him to the sheriff's office, but she argued that she could not leave the children. When he said he would arrange for their care, Henagin told him he would need to wait for her to take the curlers out of her hair and change her clothes. Shobe waited forty-five minutes for her to ready herself for the trip. ${ }^{19}$

The next morning, Henagin admitted to authorities that she saw her husband around 11:30 P.M. after the PTA meeting. ${ }^{20}$ She argued that she feared Robert Henagin was with another women that evening, Mrs. Hattie Mieritz - a family friend with whom Robert was known to spend time with alone. ${ }^{21}$ Henagin said that she and her husband had discussed divorce or separation many times, but that he would not come to a decision because she expected him to continue to support her and the children. ${ }^{22}$ Henagin claimed that she went for a walk that night and Robert Henagin pulled up next to her and told her to get in, that he wanted to take her for a ride. She said she did not want to go anywhere with him because she was not properly dressed and her hair was in curlers. He, she went on, said that her appearance did not matter because he planned to shoot her and throw her

\footnotetext{
19 "State Completes Case in Principal's Slaying," 8.

20 "State Completes Case in Principal's Slaying," 8.

21 “Her Life Threatened, Mrs. Henagin Testifies," Oregonian, December 7, 1946, 10.

22 “Her Life Threatened, Mrs. Henagin Testifies," 10.
} 
off of a cliff. At that point Robert Henagin reached for a gun that was partially hidden by a coat in the front seat. ${ }^{23}$ They struggled in the car, and when she grabbed the gun by its barrel it fired. She insisted that her husband told her he was not hurt, pushed her out of the passenger side of the car, and drove away. ${ }^{24}$

In his dying statement, Robert Henagin told District Attorney Stanley Mitchell that he was delayed coming home that night because pranksters emptied the air out of his tires. ${ }^{25}$ He also said that Henagin was never in the passenger seat, but sat in the back seat the whole time and that she shot him twice from behind without warning. After the shots were fired he then climbed into the back seat and put his leg on her neck to take the gun away from her. ${ }^{26}$

At the opening of her trial on December 3, 1946, Henagin pled not guilty to firstdegree murder before Circuit Judge Earl C. Latourette. The jury, composed of seven men and five women, was initially deadlocked eight to four and asked for a clarification in regard to the penalties that accompanied second-degree murder and manslaughter. ${ }^{27}$ Judge Latourette informed the jury that they should only concern themselves with the facts of the case and not the punishment. ${ }^{28}$ The defense attorney reminded the jury to not simply guess whether the circumstantial evidence proved Henagin was guilty. "Don't forget that here sits a poor unfortunate woman who has suffered mental torture for years,

\footnotetext{
23 "Her Life Threatened, Mrs. Henagin Testifies," Oregonian, December 7, 1946, 10.

24 "Her Life Threatened, Mrs. Henagin Testifies," 10.

25 “Guilt Denied By Woman," Oregonian, November 13, 1946, 7.

26 “West Linn Death Case Jury Locks," Oregonian, December 8, 1946, 1.

27 Though the nature of the division was not disclosed, two of the women jurors refused to sign the verdict and were convinced Henagin was guilty of manslaughter. This indicates that women jurors likely supported more severe charges in murders for gain or those that involved children, but were more possibly lenient when the motive involved an abusive or cheating partner.

28 "West Linn Death Case Jury Locks," 1.
} 
who has told a straightforward story to you, the same story she told in the sheriff's office after the shooting and to a grand jury," referring to her husband's years of infidelity. ${ }^{29}$

In the state's closing arguments, District Attorney Stanley Mitchell presented evidence procured by the state crime bureau that Robert Henagin was initially shot directly up against the cloth of his coat and that the second shot was just two inches away from his body, which made Henagin's claim of self-defense highly unlikely. ${ }^{30}$ Mitchell told the jury that anything less than a first-degree murder charge would be a "travesty on justice," as Robert Henagin had told Mitchell that he feared for a long while that "something like this would happen." 31

In the end the jury convicted Luella Henagin of second-degree murder but included a recommendation for clemency. However, a life sentence was required for a second-degree murder charge with the possibility of parole after seven and a half years. District Attorney Mitchell stated that the parole board would undoubtedly consider the jury's request for leniency when it reviewed Henagin for parole. The Oregonian reported that Henagin began her term as the twenty-eighth female prisoner at the penitentiary on December 12, 1946, and that she would likely be assigned to work in the sewing room. ${ }^{32}$ She was released on parole after she served the minimum seven and a half years. It is unknown what happened to her after her release.

\footnotetext{
29 "Prisoner Seen Cool Type," 21.

30 "West Linn Death Case Jury Locks," 1.

31 "West Linn Death Case Jury Locks," 1.

32 “Mrs. Henagin Begins Term," Oregonian, December 12, 1946, 1.
} 
First-Degree Murder Convictions, 1936-1950

The criminal components in the first-degree murders that occurred between 1936 and 1950 similarly align with some of the female defendants in earlier decades who received second-degree or manslaughter convictions. One primary difference found in this small data set was that most women murderers in this period faced female jurors at their trials. Although Oregon voters approved jury service for women in 1921, women did not serve on murder trials until the mid-1930s. ${ }^{33}$ This shift arguably undercut legal patriarchy in courtrooms.

Opponents of female jurors believed that women should be shielded from distressing crimes, evidence, and testimonies, that their rightful place was at home caring for their husband and children. ${ }^{34}$ These critics maintained that, if men and women were the same, then jury pools devoid of women would not create any disfavor, but if the sexes were actually different, women were collectively "less capable than men." 35 Supporters of women jurors, such as the League of Women Voters, argued that women were more sincere about their responsibilities than male jurors and that they were especially needed in trials that involved women and girls. ${ }^{36}$

Mid-twentieth century criminologists also observed the debate between sameness and difference between the sexes. In 1950, sociologist Otto Pollak interpreted females' behavior as relative to the social roles that they were supposed to play. Pollack argued

\footnotetext{
33 Kimberly Jensen, "Significant Events in the History of Oregon Women and Citizenship," Oregon Historical Quarterly 113, no. 3 (2012): 502, https://doi.org/10.5403/oregonhistq.113.3.0500.

${ }^{34}$ Kerber, No Constitutional Right to Be Ladies, 146.

35 Kerber, 144.

${ }^{36}$ Kerber, 144. 
that since men and women were taught that females should adhere to certain roles, any deviation from said roles was a betrayal of their womanhood. ${ }^{37}$ By engaging in violent crime, a behavior most perceived as masculine, female offenders thereby denied their own womanhood. Pollack, however, maintained that the perception of females as less criminal than men was an outdated myth that required revision. He argued that, in fact, women were inherently more deceitful than men. As such, Pollak held that deviant women often went undiscovered and unpunished for their crimes.

Pollak also argued that women's offenses did not always find their way into criminal statistics because, even when apprehended, authorities dealt with female defendants more leniently and did not charge them appropriately. He argued that men chose to ignore women's criminality to keep them in an inferior position. ${ }^{38}$ During the nineteenth century this display of power was evident by the extent of governor commutations and asylum commitments. It was more discernable in the first part of the twentieth century with the succession of manslaughter convictions. As this chapter demonstrates, compassionate opinions towards women defendants occurred between 1936 and 1950 as well. For example, Luella Henagin's jury, concerned that its verdict would lead to too harsh a sentence, required clarification from the judge before they could reach an agreement. The juries in both the Agnes Ledford [p. 84] and Gladys Broadhurst [p. 88] cases asked for leniency in sentencing. In these latter cases, both women were sentenced to life and released less than twenty years later on parole rather than receiving the death penalty.

\footnotetext{
37 Pollak, The Criminality of Women, 8-11.; Feinman, Women in the Criminal Justice System, 1994, 10. ${ }^{38}$ Feinman, Women in the Criminal Justice System, 1994, 10.
} 
The element of deceit that Pollak referenced in his work also surfaced in several newspaper articles that covered first- and second-degree murderers between 1936 and 1950. According to today's standards, most of Pollak's arguments are erroneous. However, several of his ideas were reflected in contemporary courts and periodicals and are thus pertinent to understand the actions of judges and juries. In each case there was a repeated discussion in newspaper coverage about women's ability to remain detached, dry-eyed, or to "successfully shield any qualms or emotions" in court. ${ }^{39}$ Where women were regarded as the more emotional sex, observations such as these insinuated that women's hidden emotions concealed a darker, violent person. Some women's ability to remain emotionless further perpetuated the idea that their rejection of feminine roles had led to murder.

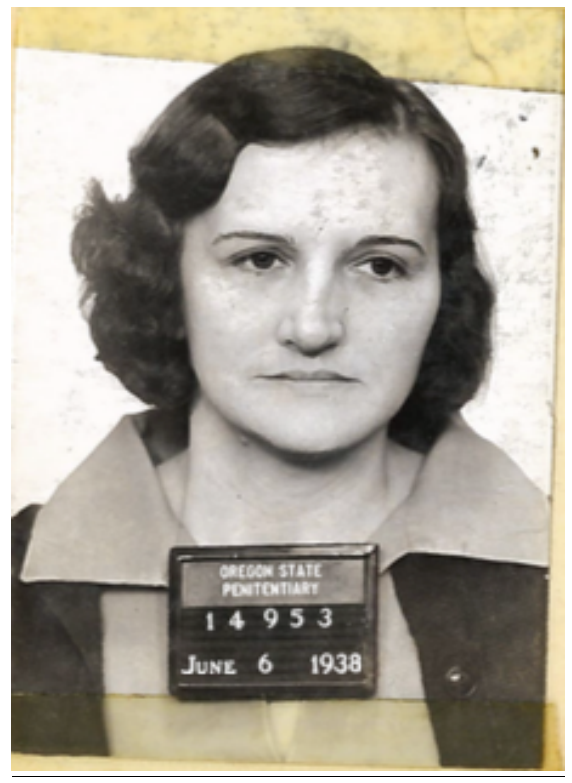

Figure 26. Agnes Ledford, June 61938. ODOC Inmate Case Files, ODOC.

39 “Accused Poisoner Attends Hymnals," 9. 
Although several of Pollack's theories about women's inherent capacity for deceit missed the mark, "deceitful" is a word that appropriately describes Agnes Ledford [Fig. 26]. In September 1932, Ledford's first husband, John Matson, was struck ill with severe stomach pains. He died several days later at their home in Albany, Oregon. Ledford, who played the part of the devoted wife, refused to leave his side during his suffering. Although his physician and the coroner were unable to determine the cause of death, authorities decided against ordering an expensive toxicology report and Matson was buried. In early 1935, Ledford met George William Ledford at an evangelical revival in Grants Pass. The pair married on March 6 of that year. George Ledford was recently divorced, and his first wife, Pearl Dayton Ledford, retained custody of their five children. ${ }^{40}$ The newlyweds moved to a farm near St. Helens that Agnes inherited from her late husband, and she soon gave birth to two sons. George Ledford, a grocery clerk, struggled to make his monthly fifty-dollar child support payments to his ex-wife and suggested that she send two of their daughters to live with him and his new wife. Ledford frequently expressed her concern about the expense of caring for two daughters that could not yet work to help support themselves. ${ }^{41}$

On August 28, 1937, the elder daughter, Dorothy Ledford, fifteen, grew ill, suffering stomach pains and vomiting. Dr. L.G. Ross attributed it to an intestinal ailment that was rampant in the district. Three nights later Dorothy Ledford and her sister Ruth Ledford, thirteen, were both sick and confined to bed. Dr. Ross instructed that well water be boiled before consumed. The girls seemed to improve with the doctor's prescribed

\footnotetext{
40 Lundy, "When Justice Triumphed: The Ledford Murder."

${ }^{41}$ Lundy. 
treatments. On September 4, 1937, Ledford left the girls with a nurse and drove into St. Helens to do some shopping. She bought a half-pound of pure arsenic at a drug store and told the druggist it was to exterminate earwigs. When she arrived home she prepared a beverage for the girls. They became severely ill, much worse than before. Dr. Ross was called, and he ordered an ambulance immediately. The girls both died within forty-eight hours. Shortly afterward the girls' uncle, Lloyd Dayton, contacted Sheriff M.L. Calhoun of Columbia County and told him he suspected foul play. ${ }^{42}$

When Sheriff Calhoun talked to Ledford about the girls' mysterious deaths, she agreed that something was strange and insisted on autopsies. The medical examiners ruled the cause of deaths as acute arsenic poisoning with traces of both lead arsenate and arsenic trioxide. ${ }^{43}$ When questioned, Ledford blamed a neighboring potato farmer who recently sprayed his crops with a lead arsenate compound. She argued that the spray had blown over to blackberry bushes that the girls frequently picked, but after testing no poison was found in the berries. Sheriff Calhoun asked to search the house and Ledford agreed. The police found the open container of white arsenic trioxide on the top shelf of a kitchen cabinet. Ledford told the sheriff that her mother, Maren Jensen, must have knocked the box off the shelf and that the girls came into contact with the spilled substance. ${ }^{44}$ The sheriff took the opened box to Portland criminologist, Stanley F. MacDonald, who determined that the box was opened with a case knife; it had not ripped

\footnotetext{
42 Fred Dickenson, “The Case of the Knife Behind the Drainboard," Oregonian, June 18, 1950, 100.

43 Dickenson, 100.

${ }^{44}$ Herbert Lundy, "Verdict Guilty in Ledford Case," Oregonian, March 31, 1938. 
open from a fall. The case knife was found behind the drain board in the kitchen, and traces of the glue were still on the blade. ${ }^{45}$

During the investigation the police learned of the mysterious death of Ledford's first husband. They exhumed Matson's body and found it full of arsenic. The police then arrested Ledford for the murder of the two girls. She was never charged with Matson's death as the prosecution feared a mistrial. ${ }^{46}$ Furthermore, six weeks before the girls died, George Ledford had purchased a one thousand dollar life insurance policy, possibly at the urging of his wife, naming Ledford the beneficiary. ${ }^{47}$ Ledford maintained her innocence throughout her trial, while District Attorney David O. Bennett insisted that she receive the death penalty. The jury, which included two women, deliberated for fifteen hours and concluded that money was Ledford's motive. They convicted her of first-degree murder, but recommended life imprisonment. Agnes Ledford was released on parole after eighteen years. ${ }^{48}$ It is unknown whether Ledford returned to live with her sons.

Killing children was a blatant rejection of the maternal role that women were supposed to play. Though this was not the first case of filicide that came before Oregon courts, it was the first that was tried before female jurors. It seems that women were more likely to find fault in other women when formerly the patriarchy refused to view them as capable of conscious criminal behavior, especially in murders that involved children. The fact that no woman had been charged with first-degree murder before Ledford's trial indicates that murder trials could not be considered equal between male

\footnotetext{
45 Dickenson, "The Case of the Knife Behind the Drainboard," 100.

${ }^{46}$ Lundy, "When Justice Triumphed: The Ledford Murder."

47 Lundy.

48 The News Review, July 30, 1956.
} 
and female defendants until after 1936. Including members of the defendant's own gender on a jury created a more credible jury of one's peers.

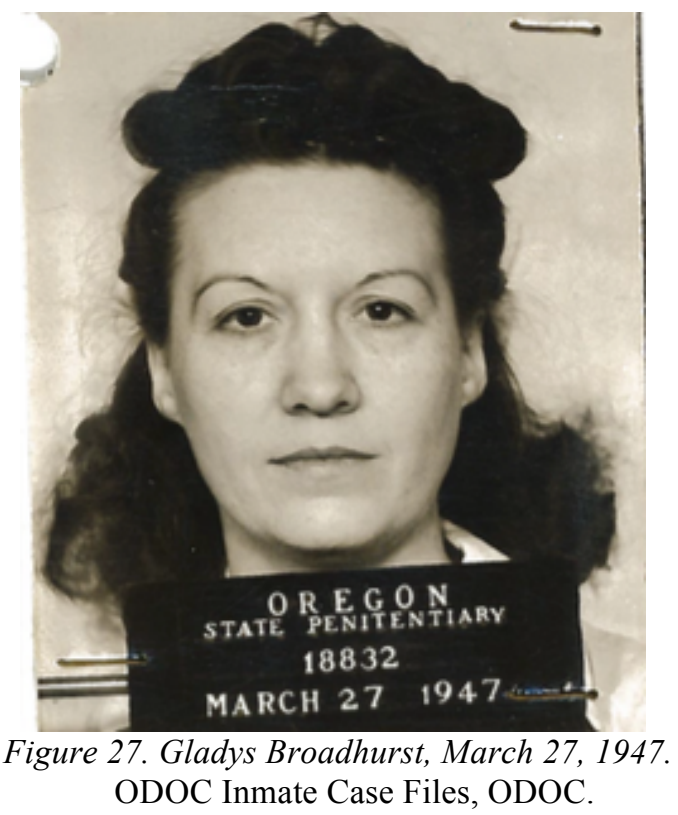

Arguably the most devious defendant in this period was Gladys Lincoln Broadhurst, the second of the two female defendants convicted of first-degree murder between 1936 and 1950 [See Fig. 27]. In the summer of 1945, Broadhurst was still technically married to her fifth husband, Lester Merle Lincoln, when she conceived a plan to marry Willis D. "Doc" Broadhurst. Doc Broadhurst was a former chiropractor turned wealthy stockman in Malheur County, Oregon, and Canyon County, Idaho. ${ }^{49}$ Forty-year-old Broadhurst used two outlandish stories to make herself an appealing marriage prospect. The first was that her aunt had recently died in Hawaii, leaving her a three million dollar inheritance. The second was that she was a widow viciously pursued by the identical twin brother of her late husband, Lester Merle Lincoln, who had been

\footnotetext{
49 “Two Charged with Murder,” Oregonian, October 19, 1946.
} 
killed overseas during WWII. ${ }^{50}$ Remarkably, though Doc Broadhurst was a friend of Gladys Broadhurst's family he apparently saw no reason that she would lie about her circumstances; they were married in Reno, Nevada on May 21, 1946.51

After returning home to Doc Broadhurst's ranch, Broadhurst gained the attention of a young cattle hand, Alvin Lee Williams, twenty-three, who periodically worked as her chauffer during haying season. ${ }^{52}$ The two were secretly married on September 17, 1946 — again in Reno. ${ }^{53}$ Broadhurst had her eyes set on Doc Broadhurst's two hundred thousand dollar estate and planned to get Williams to kill him and fix it to look like a random act of violence. On October 14, 1946, Williams followed Doc Broadhurst down a country road en route to his ranch over the Idaho border. He hit Doc Broadhurst over the head with a wrench, shot him with a shotgun, and dragged his body into the brush that lined the road. Williams then returned to Broadhurst after the calculated murder was complete.

A neighbor quickly notified Broadhurst when Doc Broadhurst's horse was found wandering without a rider. A search party formed, but she declined to join two hunts to look for her husband. ${ }^{4}$ When Broadhurst learned that a nearby rancher found Doc Broadhurst's body, she quickly responded by writing a fictitious note and shoving it under the front door of her house. The note, purportedly from her previous husband's twin brother, was an attempt to cover up that fact that Williams had committed the

\footnotetext{
50 Moxness, "Prosecutor Tells Jury Lurid Story," 1.

51 Ron Moxness, “Life, Wealth, Broadhurst Trial Stake,” Oregonian, February 25, 1947, 27.

52 “Two Charged with Murder," 10.

53 Moxness, "Suspect Wed Seven Times," 36.

54 Ron Moxness, “Note Written to 'Dear Al' Figures in Murder Trial," Oregonian, March 1, $1947,12$.
} 
murder. It stated: "Your cowboy strong-arm didn't do it, but don't start anything. I'll get you as I got Doc. I warn you, I need cash. -Sweetpea." 55 A handwriting specialist later identified that the handwriting belonged to Broadhurst, as well as a forged note from her "aunt" regarding her inheritance of three million dollars. ${ }^{56}$ In addition to all of this, the court learned that her previous husband, Lester Lincoln, was still alive and did not have any brothers.

Newspapers portrayed Gladys Broadhurst as a greedy and scheming woman who took advantage of at least two of her husbands and ordered the murder of a third. They directed attention to her "marital adventures" and the fact that she was married and divorced several times. ${ }^{57}$ Prosecuting attorney Blaine Hallock described Broadhurst as a contemporary "Lady Macbeth," a wife who ceaselessly encouraged her husband to murder. ${ }^{58}$

Broadhurst's jury was made up of nine men and three women. At her trial in February 1947, it was difficult to find jurors without a preconceived opinion about the case or feelings of hostility toward capital punishment. ${ }^{59}$ Williams eventually confessed to the murder and told the jury that Broadhurst planned the entire event. The prosecution called for the death penalty on the grounds that the murder would not have occurred without her bidding. District Attorney Charles W. Swan stated in his closing remarks to

\footnotetext{
55 Ron Moxness, "State Cites 3 Murder Plots," Oregonian, February 28, 1947, 26.

56 Ron Moxness, "Expert Connects Defendant to Note in Broadhurst Case," Oregonian, March 9, 1947, 23.

57 Moxness, "Suspect Wed Seven Times," 36.

58 Moxness, "Prosecutor Tells Jury Lurid Story," 1.

${ }^{59}$ Moxness, "Suspect Wed Seven Times," 36.
} 
the jury that "For two long weeks you have observed her charm and magnetism. I think it has made itself felt in every person she has met."60

Defense Attorney Patrick J. Gallagher asked the jury "not to judge the defendant too harshly." 61 Although her adultery was "indefensible," he argued the jury should "lay her transgressions off to one side and judge her criminality by itself."62 On March 13, 1947, the jury convicted Broadhurst of first-degree murder but asked Judge M.A. Biggs for leniency. Both Broadhurst and Williams were sentenced to life imprisonment. She was released on parole after serving nine years of her life sentence. What happened to her after her release is unknown.

Broadhurst's case was similar to others in prior decades when a female defendant elicited help from a family member or lover to commit murder. ${ }^{63}$ However, this was the first time the female conspirator was charged with first-degree murder. The jury's request for leniency worked in her favor, as did the parole system. Broadhurst represented everything society discouraged in a woman. She was a liar, an adulteress, and a murderer. Yet, she still received leniency.

\section{Conclusion}

Sentencing women to life in prison was only a latent possibility in Oregon until women jurors served on murder trials. ${ }^{64}$ Between 1936 and 1950 the punishments women

\footnotetext{
60 Ron Moxness, "Broadhurst Testimony Concluded," Oregonian, March 13, 1947, 1.

61 Ron Moxness, "Verdict in Broadhurst Case to Bring Plea for New Trial," Oregonian, March 14, 1947, 22.

62 Moxness, 22.

63 This was the first case in over thirty years where a woman elicited help from a man to help with a murder.

64 The last life sentence was given to Minnie Crockett for second-degree murder in 1900. Crockett served eight years before the governor commuted her sentence.
} 
received for murder began to better fit the crimes. The first woman to be charged with first-degree murder had two women on her jury and the second defendant had three. ${ }^{65}$ Though conceptions of women's nature persisted through time, in these two cases female jurors may have provided the catalyst to convince male jurors that women were indeed capable of violent crimes and deserving of more serious convictions. However, both of the women convicted with first-degree murder during this period only served a portion of their life sentences. Agnes Ledford served just over eighteen years while Gladys Broadhurst was released after nine. Though jurors and judges were prepared to convict and sentence women more harshly than in previous periods, it seems that during this period the parole board and prison officials remained eager to release them.

After 1936, excuses were still made for how a woman could be driven to commit a violent act. Since violence was not viewed as an inherent characteristic in women, it was necessary to instead focus on different traits that might explain violent actions. Reporters and prosecuting attorneys focused heavily on the element of deceit exhibited by several of the defendants in this period. These allegations aligned with Otto Pollack's interpretations of female criminality. ${ }^{66}$ Though homicidal women were treated more seriously in this period, their crimes were not considered contemptible enough to warrant the death penalty.

In cases where women were indicted for first-degree murder, jurors were only chosen if they had no aversion to capital punishment. Capital punishment had been reinstated on June 18,1920 , with the provision that the penalty for first-degree murder

\footnotetext{
65 Lundy, "Verdict Guilty in Ledford Case.;" Moxness, "Suspect Wed Seven Times."
}

66 Pollak, The Criminality of Women. 
was death by gas, unless the jury recommended life imprisonment [See Table $3 \& 4$ ]. But since the crimes of Ledford and Broadhurst qualified as domestic homicide, jurors recommended leniency. 


\section{Conclusion/Epilogue}

While some scholars suggest that there was a type of chivalry present in courtrooms that protected women from receiving the convictions or sentences that they deserved, others attribute these decisions to deep-seated societal anxieties regarding the devious or evil nature of women. Most discussions regarding women and crime combine these two modes of thought: "Women are presumed to commit heinous crimes because they are women and therefore potentially evil, but society hesitates to punish them because they are women and therefore deserving of protection."1 This contradiction is the “double-bind of womanhood."2

This thesis has explored this double-bound perception of female murderers within the male-dominated judicial and penal systems in Oregon. It examined how attitudes and responses toward these women transitioned according to advancements in psychiatry, criminology, legislative changes initiated by the Progressive Era, and women's campaigns for jury rights. This study adds to existing scholarship of feminist criminology by examining the individual cases of twenty-five Oregon women convicted of homicide over three periods: 1854-1900, 1901-1935, and 1936-1950. Additionally, it builds on the work of other scholars who have examined females in male penitentiary systems and mental institutions, women who kill, and women's rights.

Over the course of a century there were three distinct trends in the treatment of female murderers in Oregon. In the first period, between 1854 and 1900, women

\footnotetext{
${ }^{1}$ Renée Heberle, “Disciplining Gender; Or, Are Women Getting Away with Murder?," Signs 24, no. 4 (1999): 1107.

2 Heberle, 1107. 
murderers were considered an unnatural irregularity. The assumption that it was impossible for a woman to commit murder linked claims of insanity with criminality. ${ }^{3}$ As such, the women defendants during this period were either assumed insane and transferred to the asylum or quickly released from prison to avoid potential controversy or additional expense.

Between 1901 and 1935, Progressive movements affected how women who killed were handled in the courtroom. Sentimental juries felt more comfortable convicting women of manslaughter in lieu of first-degree murder and possible capital punishment, or second-degree murder, which warranted a mandatory life sentence. Many of those convicted of manslaughter instead received indeterminate sentences and several were released on parole. Indeterminate sentencing and the parole system aligned with the common perception that women were more capable of rehabilitation.

After gaining the right to vote and serve on juries, women began to be viewed more equally in the eyes of the law. Between 1936 and 1950 there was a more even distribution of manslaughter, second-degree murder, and first-degree murder convictions for women defendants. This is due in part to women's more constant presence in the public sphere. The idea that women were submissive creatures that required the authority and protection of men diminished. Excuses of momentary insanity or justified homicides no longer held up in court. ${ }^{4}$ In several cases these older explanations of female homicide were replaced with interpretations of the deceitful nature of women. However, even

\footnotetext{
3 Annulla Linders and Alana Van Gundy-Yoder, "Gall, Gallantry, and the Gallows: Capital Punishment and the Social Construction of Gender, 1840-1920," Gender and Society 22, no. 3 (2008): 334-35.

4 This is largely due to the use of expert witnesses.
} 
when women were charged with first-degree murder their punishments remained more lenient than men's - likely due to the domestic nature of their crimes.

This analysis of the twenty-five women convicted of murder between 1854 and 1950 makes it apparent that there are several avenues of research that need further study. For example, it would be beneficial to look more closely at developments in court proceedings and jury selection to understand the seemingly arbitrary charges, convictions and sentences that women received. Also, a study of the frequency and circumstances of acquitted female murder suspects, or those who committed other felonies would offer a more complete data set. A comparative analysis of men who committed homicide in Oregon and their punishments would provide a more comprehensive evaluation. Inquiry into how women of different ethnicities or immigrant identities were represented in newspapers and the courtroom. ${ }^{5}$ Additionally, further investigation into Oregon State Penitentiary's (OSP) biannual reports may offer some clues into the daily routines of female inmates and a more detailed picture of how women murderers were treated in prison.

It would similarly be useful to examine more recent trends in the trials and incarceration of female murderers in Oregon. Since 1950, Oregon has remained slow to recognize the need for women's correctional facilities. Women were incarcerated in the same prison as men for over a century before the Oregon Women's Correctional Center (OWCC) opened in 1965 adjacent facility to OSP. In 2001, the Coffee Creek Correctional Facility (CCCF), a 108-acre, 1,280-bed all-women prison in Wilsonville

\footnotetext{
${ }^{5}$ For example, Nunnie Williams, Martha Jane Vernon, and Doreene de Selva. 
replaced the 200-bed OWCC. The number of women incarcerated in the Oregon prison system tripled in the past twenty years. According to the Criminal Justice Commission, between 2007 and 2015 the population of female prisoners in Oregon increased by nearly 22 percent, while male prisoners increased by just 2.5 percent. ${ }^{6}$

Though Justice Reinvestment programs are in place to limit inmate population growth, CCCF is regularly maintained at capacity. As of January 2018 there were 1,304 women in prison versus 13,429 men. ${ }^{7}$ Over the past few years there has been a push from prison administrators to open an additional women's prison in Oregon. Lawmakers who are wary of the cost have shot down these attempts calling instead for steps to "contain the growth of the female prison populations." the rising population of women criminals is reminiscent of previous periods when prison and government officials refused to acknowledge the need.

This thesis provides a historical foundation for current discussions regarding the potential necessity for an additional women's penitentiary in Oregon. It offers important context into how lesser severity continues to be placed on domestic homicide and argues this is one reason why women murderers throughout Oregon history have given the noose the slip. Additionally, this thesis expounds on existing scholarship that examines how

\footnotetext{
${ }^{6}$ This is largely due to changes in sentencing structure and not an actual increase in crimes committed. In 2008 Measure 57 passed that increased sentences for certain property and drug crime offenses. These types of crimes are frequently committed by women.; Beth Slovic, "Oregon Was About to Open a Second Women's Prison Because of 25 Inmates," Willamette Week, September 16, 2016, http://www.wweek.com/news/2016/09/16/oregon-almost-opened-a-second-womens-prison-for-25prisoners/.

7 Oregon Department of Corrections, "Oregon Department of Corrections Quick Facts," Issue Brief, January 2018, http://www.oregon.gov/doc/OC/docs/pdf/IB-53-Quick\%20Facts.pdf.

8 “Lawmakers Reject Request for Funding for Women's Prison," Associate Press, December 13, 2016, https://www.statesmanjournal.com/story/news/politics/2016/12/13/lawmakers-reject-request-fundingwomens-prison/95381742/.
} 
gender has historically influenced the decisions and actions of court and prison officials. When women acted outside of their defined gender roles, men in the court and prison system reacted in accordance with the social, cultural, and legislative context of the period. Furthermore, this research demonstrates an alternate way to study gender in the social and legal landscape of the state.

\section{Epilogue}

Since 1950, two women have been sentenced to death in Oregon. In 1961, Jeannace Freeman and her lover, Gertrude Jackson, threw Jackson's two young children off of a bridge into Crooked River Canyon. Freeman was sentenced to death for firstdegree murder. She was opportunely saved by Oregon voters' decision in 1964 to repeal capital punishment and Governor Mark Hatfield commuted her death sentence. Freeman was released from the Oregon Women's Correctional Center (OWCC) in 1985, only to return to prison for a parole violation. The other woman sentenced to death for murder was Angela McAnulty. In 2009, McAnulty tortured and starved her fifteen-year-old daughter, which led to her horrific death in their Eugene home. McAnulty currently resides in the dedicated death row jail cell at Coffee Creek Correctional Facility (CCCF) and will likely remain there for the rest of her life as no one, man or woman, has been legally executed in Oregon since 1997.9

The death penalty is only applied to what society deems the most heinous of crimes. Historically, women do not commit the crimes perceived as eligible for capital punishment as often as men. Though the crimes of Freeman and McAnulty qualify as

\footnotetext{
${ }^{9}$ In November 2011, Governor John Kitzhaber placed a moratorium on executions in Oregon. Kitzhaber's successor, Governor Kate Brown has upheld the moratorium.
} 
domestic homicides, political scientist Renee Heberle has argued that when women commit violent acts within the private sphere and end up on death row it is because they "do not enact a properly feminine gender identity," or socially acceptable female behaviors..$^{10}$ Freeman was a lesbian who convinced her partner that the only way for them to be together was to rid themselves of children. Her sexual preference and opposition to motherhood blatantly disregarded socially mandated roles. McAnulty had previously been arrested for drug charges and Child Protective Services had removed her children from her care. ${ }^{11}$ Her previous criminal record, proven incompetence as a mother, and drawn out torture of her daughter likely contributed to the jury's decision to convict her of first-degree murder without a recommendation of leniency.

\footnotetext{
${ }^{10}$ Heberle, "Disciplining Gender; Or, Are Women Getting Away with Murder?," 1106.

${ }^{11}$ Charles Montaldo, "Angela McAnulty - The Worst Child Abuser in Oregon's History," ThoughtCo, January 4, 2018, https://www.thoughtco.com/crimes-of-child-killer-angela-mcanulty-973491.; McAnulty's two sons chose to stay with their foster families instead of living with her after she was released on parole.
} 
Bibliography

\section{Primary Sources:}

“10-Year Term Given Woman.” Oregonian, November 6, 1947.

"Accused Poisoner Attends Hymnals." Oregonian, November 1, 1937.

"Advertisement for Oregon Hospital and Insane Asylum," Oregonian, July 23, 1862

Albany Herald Disseminator. October 4, 1895.

Albany Herald Disseminator. November 28, 1895.

Alexander, George. "Inquiry Concerning Carrie Kersh," March 13, 1940. OSP Inmate

Case Files Box 17 Folder 6362-6381. Oregon State Archives, Salem, Oregon.

“An Accessory's Statement. Pete Sullivan's Story Of The Murder Of J. N. Brown." Oregonian, March 9, 1882.

Barrick, C.W. "Report to Parole Board," July 3, 1928. Inmate Case Files Box 37 Folder 9231-9246. Oregon State Archives, Salem, Oregon.

—. "Statement of the Crime as Part of the Report to Parole Board," July 3, 1928. Inmate Case Files Box 37 Folder 9231-9246. Oregon State Archives, Salem, Oregon.

"Board of Parole and Post-Prison Supervision Administrative Overview December 2006." Accessed May 3, 2017.

http://sos.oregon.gov/archives/Documents/recordsmgmt/sched/overview-parolepost-prison-supervision.pdf.

"Booth Case Ends; Jury Is Closeted. Circuit Judge Belt Tells Men They Have Nine Forms of Verdict Open." Oregonian, December 7, 1915.

"Brown's Body Identified. The Prosecution in the Case of Carrie Bradley Make Several Strong Points." Oregonian, May 27, 1882.

Cameron, George. Indictment, The State of Oregon vs. Carrie Kersh (1910).

"Caroline Briggs, c. 1870," Dennis E. Strayer Collection, Kerbyville Museum, Kerbyville, Oregon.

"Charge of Murder Faced by Woman." Oregonian, November 10, 1928.

"Convicted Woman Cries Sentence Will Be Pronounced Today upon Mrs. Anna Booth M’Minnville, Or., March 12." Oregonian, March 13, 1916.

Court Officials of Washington County. "Observations of Officials and Record of Discipline," 1931. OSP Inmate Case Files Box 64 Folder 11959-11969. Oregon State Archives, Salem, Oregon.

Democratic Times. November 6, 1874.

Democratic Times. July 2, 1875.

Democratic Times. July 9, 1875.

Democratic Times, July 9, 1875.

Dickenson, Fred. "The Case of the Knife Behind the Drainboard." Oregonian, June 18, 1950.

Diller, Adam. Verdict, State of Oregon v. Nunnie Williams, Pub. L. No. C-5015 (1916).

East Oregonian. October 5, 1900.

East Oregonian. October 9, 1900.

East Oregonian. October 12, 1900. 
East Oregonian. October 13, 1900.

East Oregonian. October 18, 1900.

East Oregonian. October 19, 1900.

East Oregonian. October 20, 1900.

Evans. "Mental Examination by Dr. Evans at Oregon State Hospital," January 13, 1937. OSP Inmate Case Files Box 64 Folder 11959-11969. Oregon State Archives, Salem, Oregon.

"Evidence Against Woman Stronger. Both Jesse Webb and Mrs. Kersh Indicted for First Degree Murder.” Oregonian, June 25, 1910.

"Ex-Chorus Girl Is Hazel Erwin. Eye Witness to Wallace Murder Once Frolicked on Barbary Coast." Oregonian, June 28, 1912.

"Executions in the U.S. 1608-2002: The ESPY File," n.d. https://deathpenaltyinfo.org/documents/ESPYstate.pdf.

"Executive Clemency. Number Of State Prisoners That Have Been Pardoned, Or Had Their Sentences Commuted.” Oregonian, April 8, 1879.

"Girl Gets Three Years." Oregonian, May 19, 1927.

“Guilt Denied By Woman.” Oregonian, November 13, 1946.

Hagglund, A.E. "Letter from District Attorney, A.E. Hagglund, to OSP Warden, J.W. Lewis," August 17, 1935. Inmate Case Files Box 37 Folder 9231-9246. Oregon State Archives, Salem, Oregon.

Hawthorne, J.C. "Report of the Physicians of the Oregon Hospital of the Insane for the Years 1863-64." W.A. McPherson State Printer, n.d.

Hennessy, Duane. “Grand Central Murder... A Trunk Mystery.” Oregonian, September $15,1935$.

"Her Life Threatened, Mrs. Henagin Testifies." Oregonian, December 7, 1946.

Hewitt, Louis. Motion, State of Oregon vs. Yvonne Littell, Pub. L. No. C-12644 (1927).

Indictment, State of Oregon vs. Grace Violette, Pub. L. No. C-12036 (1926).

Indictment, State of Oregon vs. Susie Owens, Pub. L. No. C-2658 (1912).

Indictment, State of Oregon vs. Yvonne Littell, Pub. L. No. C12644 (1927).

https://doi.org/10.5403/oregonhistq.113.3.0500.

"Jilted Woman Shoots. Italian Is Wounded by Divorcee He Refused to Marry." Oregonian, July 13, 1912.

Judgment, State of Oregon vs. Grace Violette, Pub. L. No. C-12036, Judgment No. 7310A (1926).

Judgment, State of Oregon vs. Susie Owens, Pub. L. No. C-2658, Judgment No. 50050 (1912).

Judgment, State of Oregon vs. Yvonne Littell, Pub. L. No. C-12644, Judgement No. 13284A (1927).

"Jury Decides Woman Guilty." Oregonian, November 16, 1950.

"Jury Disagrees in Booth Murder Case. Four Men Hold out 28 Hours for Acquittal." Oregonian, December 8, 1915.

Kelly, Paul. "State Board of Parole and Probation Release Document," January 25, 1940. OSP Inmate Case Files Box 64 Folder 11959-11969. Oregon State Archives, Salem, Oregon.

"Killer of Child Indicted by Jury." Oregonian, April 26, 1925. 
Latourell, Christine. "Letter from Christine Latourell to OSP Superintendent, H.W. Meyers," August 23, 1927. Inmate Case Files Box 39 Folder 9559-9579. Oregon State Archives, Salem, Oregon.

"Lawmakers Reject Request for Funding for Women's Prison." Associate Press. December 13, 2016. https://www.statesmanjournal.com/story/news/politics/2016/12/13/lawmakersreject-request-funding-womens-prison/95381742/.

Lewis, J.W. "Letter from J.W. Lewis, OSP Warden, to Oregonian Reporter, Duane Hennessy," November 26, 1935. Inmate Case Files Box 25 Folder 7670-7688. Oregon State Archives, Salem, Oregon.

- "Letter from OSP Warden, J.W. Lewis to District Attorney, A.E. Hagglund," August 21, 9135. Inmate Case Files Box 37 Folder 9231-9246. Oregon State Archives, Salem, Oregon.

"Life Term in Penitentiary." Oregonian, November 3, 1900.

Lombroso, Cesare. The Female Offender. D. Appleton and Company, 1895.

Lundy, Herbert. "Verdict Guilty in Ledford Case." Oregonian, March 31, 1938. . "When Justice Triumphed: The Ledford Murder." Oregonian, September 11, 1938 .

Lunsford, W.B., S.E. Josephi, and H.W. Williamson. "Letter to Judge Louis Hewitt from Doctors at Mountain View Sanitarium Co.," May 14, 1927. Multnomah County Circuit Court Archives.

Mallet, L.H. "Discharge of Parole and Probation," October 28, 1957. Oregon Department of Corrections.

Meyers, Stanley. Indictment, The State of Oregon vs. Doreene de Selva, Pub. L. No. C14214 (1928).

Montaldo, Charles. "Angela McAnulty - The Worst Child Abuser in Oregon's History." ThoughtCo, January 4, 2018. https://www.thoughtco.com/crimes-of-child-killerangela-mcanulty-973491.

Morrow, Robert. “'Charge of Court,'State of Oregon v. Carrie Kirsh".” Multnomah County Circuit Court, December 17, 1900. Multnomah County Circuit Court Archives.

_ . "Report to Parole Board, State of Oregon, Statement of Judge," August 5, 1929. Inmate Case Files Box 49 Folder 10516-10519. Oregon State Archives, Salem, Oregon.

— Trial Order, The State of Oregon vs. Doreene de Selva, Pub. L. No. C-14214 (1928).

Moxness, Ron. "Broadhurst Testimony Concluded." Oregonian, March 13, 1947.

—. "Expert Connects Defendant to Note in Broadhurst Case." Oregonian, March 9, 1947.

. "Life, Wealth, Broadhurst Trial Stake." Oregonian, February 25, 1947.

—. "Note Written to 'Dear Al' Figures in Murder Trial." Oregonian, March 1, 1947.

—_. "Prosecutor Tells Jury Lurid Story.” Oregonian, February 28, 1947.

. "State Cites 3 Murder Plots." Oregonian, February 28, 1947. . "Suspect Wed Seven Times." Oregonian, February 25, 1947. 
_ . "Verdict in Broadhurst Case to Bring Plea for New Trial." Oregonian, March 14, 1947.

"Mrs. Crockett; Eastern Oregon." Oregonian, October 21, 1900.

“Mrs. Emma Hannah’s Imprisonment Telling Upon Her." Oregonian, March 17, 1896.

"Mrs. Henagin Begins Term." Oregonian, December 12, 1946.

"Mrs. Kersh Tells Tangled Stories Woman in Webb Murder Case Said to Have Been Married to Johnson." Oregonian, October 20, 1910.

"Negress Story Mixed Slayer's Self Defense Plea Suffers on Stand." Oregonian, January $18,1916$.

"Oregon Department of Corrections Inmate Case File \#13730, Margaret Hart," Offender Information and Sentence Computation, Oregon Department of Corrections, Wilsonville, Oregon.

"Oregon Department of Corrections Inmate Case File \#14953, Agnes Ledford," Offender Information and Sentence Computation, Oregon Department of Corrections, Wilsonville, Oregon.

"Oregon Department of Corrections Inmate Case File \#16445, Julia Carlson," Offender Information and Sentence Computation, Oregon Department of Corrections, Wilsonville, Oregon.

"Oregon Department of Corrections Inmate Case File \#18670, Luella Henagin," Offender Information and Sentence Computation, Oregon Department of Corrections, Wilsonville, Oregon.

Oregon Department of Corrections Inmate Case File \#18832, Gladys Broadhurst, Offender Information and Sentence Computation, Oregon Department of Corrections, Wilsonville, Oregon.

"Oregon Department of Corrections Inmate Case File \#19167, Helen Rookard," Offender Information and Sentence Computation, Oregon Department of Corrections, Wilsonville, Oregon.

"Oregon Department of Corrections Inmate Case File \#21114, Atlee Marie Chaboude," Offender Information and Sentence Computation, Oregon Department of Corrections, Wilsonville, Oregon.

"Oregon Hospital for the Insane on SE Hawthorne Avenue, c. 1872," OrHi 26037, Oregon Historical Society.

"Oregon State Hospital Death Book, 1912-1936," n.d. Vol. 2G. Oregon State Archives, Salem, Oregon.

Oregon State Penitentiary. "Great Register," 1946 1854. Oregon State Archives, Salem, Oregon.

"Oregon State Penitentiary Biennial Reports." Salem, Oregon: Oregon State Penitentiary, n.d. Oregon State Archives, Salem, Oregon.

"Oregon State Penitentiary Case File \#444, Mike McCormick," n.d. Oregon State Archives, Salem, Oregon.

"Oregon State Penitentiary Inmate Case File \#8, Charity Lamb," Box 1 Folder 8, 288, 313, 409, 421, 445, 837, 974, 1643, 1677, 1716, 1899. Oregon State Archives, Salem, Oregon. 
“Oregon State Penitentiary Inmate Case File \#3548, Emma Hannah,” Box 6 Folder 35403550. Oregon State Archives, Salem, Oregon.

"Oregon State Penitentiary Inmate Case File \#4304, Minnie Crockett," Box 9 Folder 4304-4320. Oregon State Archives, Salem, Oregon.

"Oregon State Penitentiary Inmate Case File \#6367, Carrie Kersh," Box 17 Folder 63626381. Oregon State Archives, Salem, Oregon.

“Oregon State Penitentiary Inmate Case File \#6686, Hazel Erwin,” Box 19 Folder 66706691. Oregon State Archives, Salem, Oregon.

“Oregon State Penitentiary Inmate Case File \#6687, William Tanner," Box 19 Folder 6670-6691. Oregon State Archives, Salem, Oregon.

"Oregon State Penitentiary Inmate Case File \#6693, Susie Owens," Box 19 Folder 66926712. Oregon State Archives, Salem, Oregon.

“Oregon State Penitentiary Inmate Case File \#7518, Nunnie Williams," Box 23 Folder 7507-7525. Oregon State Archives, Salem, Oregon.

“Oregon State Penitentiary Inmate Case File \#7681, William Branson," Box 25 Folder 7670-7688. Oregon State Archives, Salem, Oregon.

"Oregon State Penitentiary Inmate Case File \#7684, Anna Booth," Box 25 Folder 76707688. Oregon State Archives, Salem, Oregon.

"Oregon State Penitentiary Inmate Case File \#9246, M.C. Paton," Box 37 Folder 92319246. Oregon State Archives, Salem, Oregon.

“Oregon State Penitentiary Inmate Case File \#9578, Grace Violette," Box 39 Folder 9559-9579. Oregon State Archives, Salem, Oregon.

“Oregon State Penitentiary Inmate Case File \#9880, Yvonne Littell," Box 42 Folder 9879-9880. Oregon State Archives, Salem, Oregon.

"Oregon State Penitentiary Inmate Case File \#10516, Doreene de Selva," Box 49 Folder 10516-10519. Oregon State Archives, Salem, Oregon.

“Oregon State Penitentiary Inmate Case File \#11489, Ruth Warnock," Box 59 Folder 11482-11489. Oregon State Archives, Salem, Oregon.

"Oregon State Penitentiary Inmate Case File \#11961, Laura Potts," Box 64 Folder 1195911969. Oregon State Archives, Salem, Oregon.

“Oregon State Penitentiary Inmate Register,” n.d. Vol. 3, 1877-1887, Inmate \#1243. Oregon State Archives, Salem, Oregon.

"Oregon Supreme Court Appeals File, Affidavit of Carrie Briggs, Age 17," October 29, 1874. Oregon State Archives, Salem, Oregon.

Oregonian, June 25, 1889.

Oregonian, September 26, 1935.

"Personal and Medical History of Emma G. Hannah," November 11, 1898. Oregon State Archives, Salem, Oregon.

"Personal and Medical History of Emma G. Hannah," June 23, 1900. Oregon State Archives, Salem, Oregon.

"Police Doubt Girl. Officers Think Hazel Erwin Is Shielding Murderer." Oregonian, June 30, 1912.

Pollak, Otto. The Criminality of Women. Philadelphia: University of Pennsylvania Press, 1950.

"Principles in the Milton Murder." Oregonian, October 21, 1900. 
"Prisoner Seen Cool Type." Oregonian, December 8, 1946.

"Questionnaire of No. 13730," January 6, 1936. Oregon Department of Corrections.

Senate, Oregon Legislative Assembly. Journal of the Proceedings of the Senate, of the Legislative Assembly of Oregon, 1899.

"Shot Is Fired Blindly. Susie Owens Says She Did Not Know for Whom." Oregonian, October 10, 1912.

Slovic, Beth. "Oregon Was About to Open a Second Women's Prison Because of 25 Inmates." Willamette Week. September 16, 2016. http://www.wweek.com/news/2016/09/16/oregon-almost-opened-a-secondwomens-prison-for-25-prisoners/.

"State Completes Case in Principal's Slaying." Oregonian, December 6, 1946.

"State of Oregon v. Caroline Briggs, No. 878, File No. 0777, Journal Entry: Vol. 5, P. 524," July 5, 1875. Oregon State Archives, Salem, Oregon.

"State of Oregon v. Caroline Briggs, Oregon Supreme Court Appeals File. Affidavit of Daniel Green, Sheriff," April 26, 1875. Oregon State Archives, Salem, Oregon.

"State of Oregon v. David and Caroline Briggs, Affidavit by George E. Briggs," October 28, 1874. Oregon State Archives, Salem, Oregon.

"State of Oregon v. David Briggs, Jackson County Circuit Court State 1 File 32," October 28, 1874. Oregon State Archives, Salem, Oregon.

"State of Oregon v. Mary McCormick, Clatsop County Circuit Court Files, Book 4, Page 489," August 7, 1876.

State of Oregon vs. Carrie Bradley, Pub. L. No. 6681 (1879).

State of Oregon vs. Carrie Bradley, Pub. L. No. 8194 (1881).

State of Oregon vs. M.P. Forst and Carrie Bradley, Pub. L. No. 6478 (1878).

Stenger, George. Affidavit, Exhibit “A” (1910).

"Suffrage Leader on Jury." Oregon Journal. December 1, 1912.

"Susie Owens Is Paroled. Woman Who Killed Fiance Said to Be Dying from Old Wounds." Oregonian, March 23, 1914.

“The Great Register.” Oregon State Penitentiary Records, n.d. Oregon State Archives, Salem, Oregon.

“The Lamb Murder Trial.” Oregon Weekly Times, September 30, 1854.

The News Review. July 30, 1956.

"The Trial Ended. Carrie Bradley Convicted of ManSlaughter Two of Her Lawyers Arrested in Open." Oregonian, June 2, 1882.

"Threat to Kill Heard at Inquest." Oregonian, April 24, 1925.

"Trial of Charity Lamb, for the Murder of Her Husband, Nathaniel J. Lamb." Oregonian, September 30, 1854.

"Two Charged with Murder." Oregonian, October 19, 1946.

Webb, Dell. Verdict, The State of Oregon vs. Doreene de Selva, Pub. L. No. C-14214 (1928).

Weekly Astorian. August 12, 1876.

"West Linn Death Case Jury Locks." Oregonian, December 8, 1946.

West, Oswald. "Our Prison System in the Days of Old," undated. Box 2, Folder 31. Oregon Historical Society.

"When Will the next Farce Be Played? In September?" Oregon Spectator, July 14, 1854. 
"Woman Charged with Slaying Bound Over." Oregonian, August 2, 1935.

"Woman Enters Guilty Plea." Oregonian, April 22, 1941.

"Woman Gets 7 Years." Oregonian, January 20, 1931.

"Woman Held in Ax Death." Oregonian, December 20, 1940.

"Woman Indicted in Death Case." Oregonian, January 4, 1941.

"Woman Indicted in Man's Death." Oregonian, June 22, 1946.

"Woman Slayer Guilty." Oregonian, May 25, 1926.

"Woman Slayer in Court." Oregonian, November 21, 1928.

"Woman to Face Murder Charge." Oregonian, July 9, 1935.

"Woman Who Slew Ex-Friend Convicted." Oregonian, January 16, 1931.

"Woman's Arraignment Due Later This Week." Oregonian, July 11, 1935.

\section{Secondary Sources:}

Adler, Jeffrey S. "“I Loved Joe, but I Had to Shoot Him': Homicide by Women in Turnof-the-Century Chicago." The Journal of Criminal Law and Criminology (1973-) 92, no. 3/4 (2002): 867-98. https://doi.org/10.2307/1144248.

Armitage, Susan H., and Elizabeth Jameson. The Women's West. 1st ed. Norman: University of Oklahoma Press, 1987.

Bakken, Gordon M., and Brenda Farrington. Women Who Kill Men California Courts, Gender, and the Press. Law in the American West. Lincoln: University of Nebraska Press, 2009.

Butler, Anne M. Gendered Justice in the American West: Women Prisoners in Men's Penitentiaries. Urbana: University of Illinois Press, 1997.

Caplan, Ruth B. Psychiatry and the Community in Nineteenth-Century America: The Recurring Concern with the Environment in the Prevention and Treatment of Mental Illness. First Edition. Basic Books, 1969.

Dann, Robert H. "Capital Punishment in Oregon." The Annals of the American Academy of Political and Social Science 284 (1952): 110-14.

Dodge, L. Mara. “'One Female Prisoner Is of More Trouble than Twenty Males': Women Convicts in Illinois Prisons, 1835-1896.” Journal of Social History 32, no. 4 (1999): 907-30.

Feinman, Clarice. Women in the Criminal Justice System. ABC-CLIO, 1994.

- Women in the Criminal Justice System. ABC-CLIO, 1994.

Friedman, Lawrence. Crime And Punishment In American History. New York, NY: Basic Books, 1994.

Geller, Jeffrey L., and Maxine Harris. Women of the Asylum: Voices From Behind the Walls, 1840-1945. New York: Anchor Books, 1994.

Gillespie, Cynthia K. Justifiable Homicide: Battered Women, Self-Defense and the Law. Ohio State University Press, 1989.

Goeres-Gardner, Diane L. Murder, Morality, and Madness: Women Criminals in Early Oregon. Idaho: Caxton Press, 2009.

Goeres-Gardner, Diane L., and John Ritter. Oregon State Penitentiary. Charleston, South Carolina: Arcadia Publishing, 2014. 
Heberle, Renée. "Disciplining Gender; Or, Are Women Getting Away with Murder?" Signs 24, no. 4 (1999): 1103-12.

Herzog, Sergio, and Shaul Oreg. "Chivalry and the Moderating Effect of Ambivalent Sexism: Individual Differences in Crime Seriousness Judgments." Law \& Society Review 42, no. 1 (2008): 45-74.

Higgens-Evenson, R. Rudy. "The Political Asylum: State Making and the Medical Profession in Oregon, 1862-1900." The Pacific Northwest Quarterly 89, no. 3 (1998): 136-48.

Hoffman, Elizabeth Lee. “The Murder Quilt: A Methodological Study Exploring Selected Research Methods, Techniques, and Procedures Used to Study Material Culture." University of Oregon, 1991.

Ireland, Robert M. "Insanity and the Unwritten Law." The American Journal of Legal History 32, no. 2 (1988): 157-72.

Jones, Ann. Women Who Kill. New York: The Feminist Press at CUNY, 2009.

Kerber, Linda K. No Constitutional Right to Be Ladies. New York: Hill and Wang, 1998.

Lansing, Ronald B. "The Tragedy of Charity Lamb: Oregon's First Convicted Murderess." Oregon Historical Quarterly, no. 101 (2000): 40-76.

Larsell, Olof. The Doctor in Oregon: A Medical History. First Edition. Binfords \& Mort, 1947.

Laythe, Joseph E. Crime and Punishment in Oregon, 1875-1915: A Study of Four Communities. The Edwin Mellen Press, 2008.

Linders, Annulla, and Alana Van Gundy-Yoder. "Gall, Gallantry, and the Gallows: Capital Punishment and the Social Construction of Gender, 1840-1920.” Gender and Society 22, no. 3 (2008): 324-48.

McAfee, Ward M. "The Formation of Prison-Management Philosophy in Oregon, 18431915." Oregon Historical Quarterly 91, no. 3 (1990): 258-84.

Jensen, Kimberly. “Kimberly Jensen's Blog: Oregon Attorney General's Decision December 10, 1912: Women Can't Serve on Juries -- Historical Connections and a Few Loopholes." Kimberly Jensen's Blog (blog), August 16, 2011. http://kimberlyjensenblog.blogspot.com/2011/08/oregon-attorney-generalsdecision.html.

. 'Kimberly Jensen's Blog: Portland's 'Experimental' Woman Jury, Part II, Oregon Journal December 1 and 2, 1912." Kimberly Jensen's Blog (blog), May 13, 2011. http://kimberlyjensenblog.blogspot.com/2011/05/portlandsexperimental-woman-jury-part_13.html.

. "Revolutions in the Machinery: Oregon Women and Citizenship in Sesquicentennial Perspective." Oregon Historical Quarterly 110, no. 3 (2009): 336-61.

- "Significant Events in the History of Oregon Women and Citizenship." Oregon Historical Quarterly 113, no. 3 (2012): 500-504.

Nedry, H. S. "Willamette Valley in 1859: The Diary of a Tour." Oregon Historical Quarterly 46, no. 3 (1945): 235-54.

Oregon Department of Corrections. "Oregon Department of Corrections Quick Facts." Issue Brief, January 2018. http://www.oregon.gov/doc/OC/docs/pdf/IB-53Quick\%20Facts.pdf. 
Peterson del Mar, David. What Trouble I Have Seen: A History of Violence Against Wives. Cambridge: Harvard University Press, 1996.

Rapaport, Elizabeth. "The Death Penalty and Gender Discrimination.” Law \& Society Review 25, no. 2 (1991): 367-84.

Rondema, Jessica. “Oregon State Penitentiary.” Accessed March 19, 2018. https://oregonencyclopedia.org/articles/oregon_state_penitentiary/\#.Wq8TfZPwZ sM.

Scull, Andrew. Madhouses, Mad-Doctors, and Madmen: The Social History of Psychiatry in the Victorian Era. Philadelphia, Pa: University of Pennsylvania Press, 1981.

Tighe, Janet A. "Francis Wharton and the Nineteenth-Century Insanity Defense: The Origins of a Reform Tradition." The American Journal of Legal History 27, no. 3 (1983): 223-53. https://doi.org/10.2307/845155.

Welter, Barbara. "The Cult of True Womanhood: 1820-1860." American Quarterly 18, no. 2 (July 1, 1966): 151-74. https://doi.org/10.2307/2711179.

Zedner, Lucia. "Women, Crime, and Penal Responses: A Historical Account." Crime and Justice 14 (1991): 307-62. 